\title{
DIVERSIDADE DE Xanthomonas SPP. ASSOCIADAS À MANCHA-BACTERIANA EM TOMATEIRO PARA PROCESSAMENTO INDUSTRIAL NO BRASIL
}

\author{
Alice Maria Quezado Duval
}

Tese apresentada à Escola Superior de Agricultura "Luiz de Queiroz", Universidade de São Paulo, para obtenção do título de

Doutor em Agronomia, Área de Concentração: Fitopatologia.

PIRACICABA

Estado de São Paulo - Brasil

Janeiro - 2003 


\title{
DIVERSIDADE DE Xanthomonas SPP. ASSOCIADAS À MANCHA-BACTERIANA EM TOMATEIRO PARA PROCESSAMENTO INDUSTRIAL NO BRASIL
}

\author{
Alice Maria Quezado Duval
}

Engenheiro Agrônomo

Orientador: Prof. Dr. Luis Eduardo ARANHa CAMargo

Tese apresentada à Escola Superior de Agricultura "Luiz de Queiroz", Universidade de São Paulo, para obtenção do título de Doutor em Agronomia, Área de Concentração: Fitopatologia.

PIRACICABA

Estado de São Paulo - Brasil

Janeiro - 2003 


\title{
D ados Intermacionais de C atal ogação na Publicação (CIP) DIVISÃO DE BIBLIOTECA E DOCUMENTAÇÃO - ESALQ/USP
}

\author{
Duval, Alice Maria Quezado \\ Diversidade de Xanthomonas spp. associados à mancha-bacteriana em tomateiro para \\ processamento industrial no Brasil / Alice Maria Quezado Duval. - - Piracicaba, 2003. \\ $111 \mathrm{p}$. : il. \\ Tese (doutorado) - Escola Superior de Agricultura Luiz de Queiroz, 2003. \\ Bibliografia.
}

1. Controle químico - avaliação 2. Diversidade genética 3. Doenças de plantas 4 . Mancha-bacteriana 5. Tomate I. Título

CDD 635.642

"Permitida a cópia total ou parcial deste documento, desde que citada a fonte - $O$ autor" 
Ao meu filho Tomás Antonio

Ao meu marido Cleison pelo incessante apoio,

com amor

DEDICO.

Em memória de meu pai Antonio Pedro

À minha mãe Maria Quezado, com carinho OFEREÇO. 


\section{AGRADECIMENTOS}

Agradeço especialmente ao Prof. Dr. Luis Eduardo Aranha Camargo pela valiosa orientação, estímulo e profissionalismo.

Aos Professores do Setor de Fitopatologia da ESALQ pelos ensinamentos.

Ao Dr. Rui Pereira Leite Júnior pelos ensinamentos, amizade e disponibilização do Laboratório de Bacteriologia do IAPAR.

A Mirtes Freitas Lima da Embrapa CPATSA pela coleta de amostras do Nordeste.

Ao Dr. Carlos Alberto Lopes da Embrapa Hortaliças e Prof. Dr. Jeffrey B. Jones da University of Florida pela revisão dos manuscritos.

Ao pessoal do Laboratório de Bacteriologia do IAPAR, em especial a Flávia, Luciana e Lázara, pela amizade e convívio saudável nos períodos passados em Londrina.

Aos colegas e amigos do curso de pós-graduação Regina Leite, Célia, Bringel, Nelson, Larissa e Eduardo pelo companheirismo e trocas de experiências.

Aos amigos do Laboratório de Genética Molecular Mariana, Adriane, Kátia, Andréia, Regina Sartori, Olga, Paulo, Daniela, Ana, Cláudia, Maeli, Alessandra, Flávia, Maria Cristina, Rodrigo, Vanoli, Camila e muitos outros que tanto alegraram nosso dia-à-dia. 
A Ademir Gazzoto pela ajuda na condução dos trabalhos práticos.

Ao amigo Raul Nakashima pelo valioso auxílio na editoração desta dissertação.

Aos funcionários Antonio e Joaquim do Laboratório de Fitopatologia da Embrapa Hortaliças e José Maria do Laboratório de Bacteriologia Vegetal do IAPAR pelos

Aos funcionários da ESALQ Marina e Jefferson pela presteza em solucionar problemas.

À bibliotecária Sílvia Zinsly pela revisão geral da tese.

À bibliotecária e amiga Maria de Fátima da Embrapa Hortaliças pela pronta disposição

Ao meu sogro Wilson, sogra Marília e cunhada Fernanda pela ajuda nos vários momentos de minha ausência.

Aos amigos Isabel Bezerra, Paulo Melo, Gilmar Henz e Marcelle Cavalcanti que mesmo distante estavam sempre presentes.

Às queridas vizinhas D. Ester pelas orações, D. Ignez, D. Zilda e ao casal Elisete e Marco Bueno que sempre prontos a ajudar muito amenizaram a saudade de casa.

A Embrapa pela oportunidade de treinamento.

Ao CNPq pela concessão da bolsa de estudos.

A todos aqueles que por esquecimento não citei mas que de alguma forma contribuíram em mais esta etapa de minha vida, agradeço. 


\section{SUMÁRIO}

Página

RESUMO viii

SUMMARY...

1 INTRODUÇÃO

2 REVISÃO DE LITERATURA

2.1 Importância da cultura .

2.2 Histórico da etiologia da mancha-bacteriana.

2.3 Sintomatologia e importância da doença .

2.4 Controle químico

2.5 Interações com a hospedeira e resistência varietal................................................................................... 8

2.6 Caracterização de Xanthomonas spp. associadas à mancha -bacteriana .................................................. 10

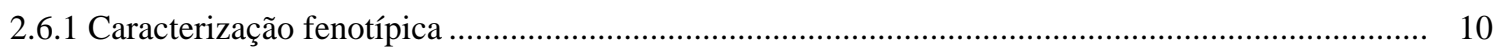

2.6.2 Caracterização genotípica................................................................................................ 12

3 EPIDEMIAS DE 'Xanthomonas gardneri’ NO BRASIL-CENTRAL ................................................... 16

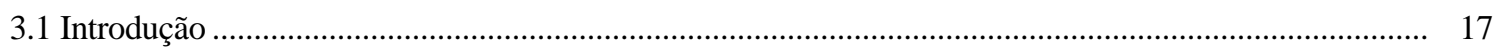

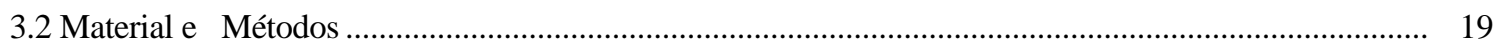

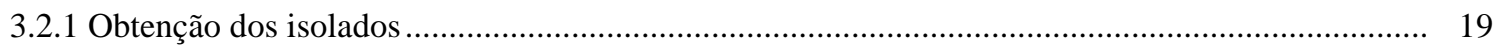

3.2.2 Perfis de macrorestrição do DNA genômico em eletroforese em campo pulsado (PFGE) ............. 21

3.2.3 Amplificação do fragmento relacionado ao gene $a v r R x v$............................................................ 23

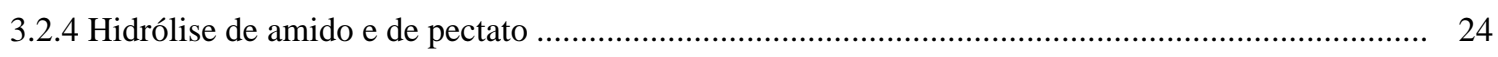

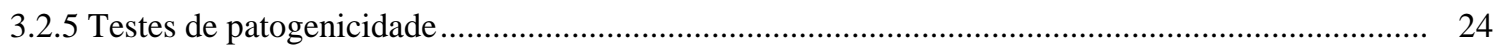

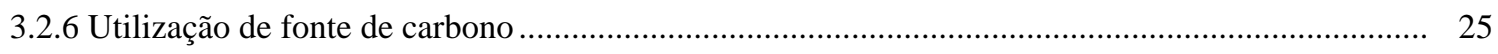

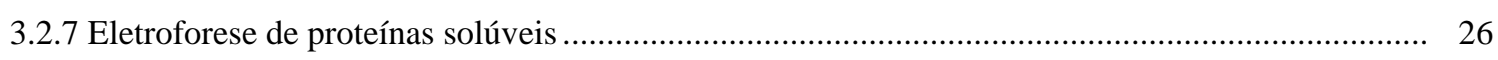

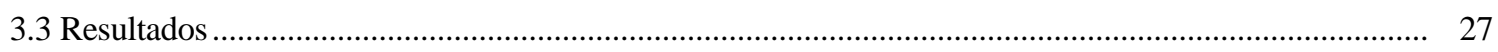

3.3.1 Análise de PFGE e detecção do gene $a v r R x v$................................................................................. 27

3.3.2 Caracterização fenotípica ........................................................................................................ 30 
3.3.3 Identificação das espécies e freqüência ................................................................................. 32

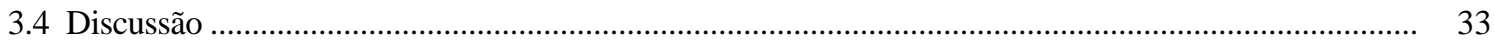

4 DIVERSIDADE GENÉTICA DE Xanthomonas SPP. ASSOCIADAS À MANCHA-BACTERIANA NAS MACRO-REGIÕES PRODUTORAS BRASIL-CENTRAL E NORDESTE ...................................... 36

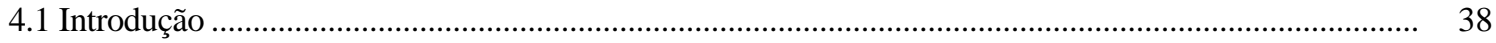

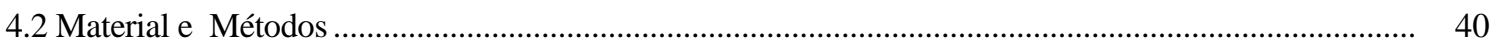

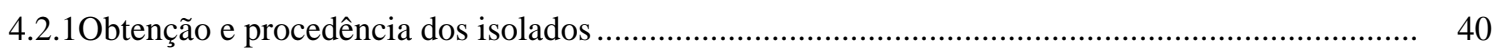

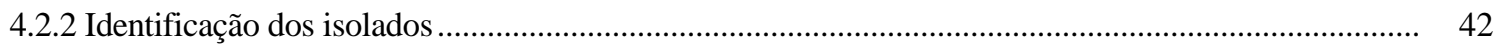

4.2.3 Análise da diversidade genética ........................................................................................... 43

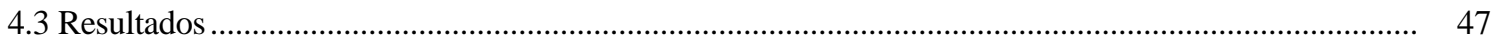

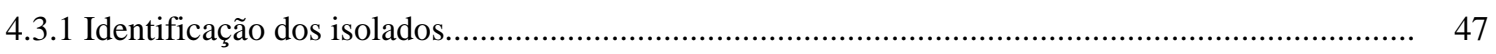

4.3.1 Análise da diversidade genética ......................................................................................... 54

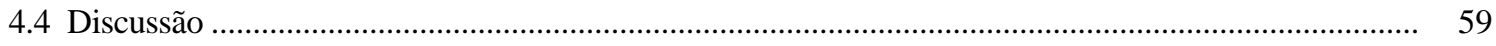

5 OCORRÊNCIA DE RAÇAS DE Xanthomonas SPP. EM PLANTIOS COMERCIAIS DO BRASIL-

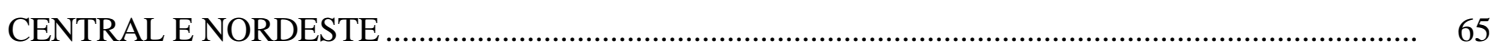

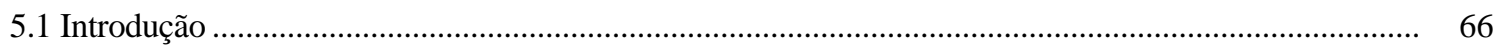

5.2.1 Obtenção, manutenção e identificação dos isolados..................................................................... 70

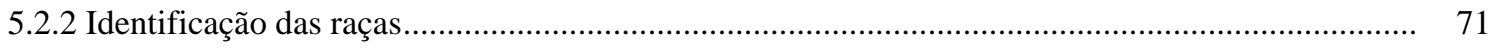

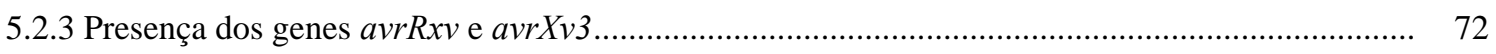

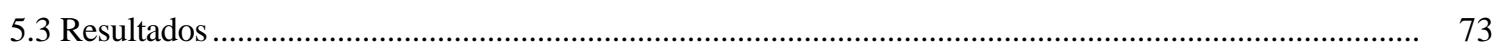

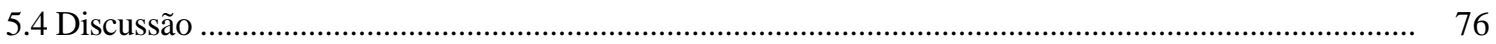

6 SENSIBILIDADE AO COBRE, ESTREPTOMICINA E OXITETRACICLINA EM Xanthomonas SPP. ASSOCIADAS À MANCHA-BACTERIANA DO TOMATEIRO RASTEIRO ........................................ 80

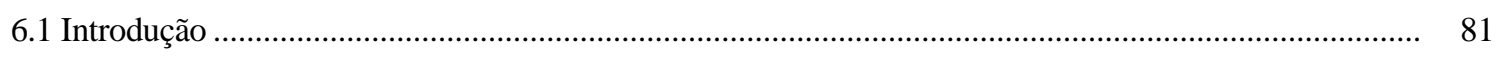

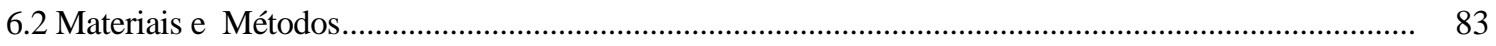

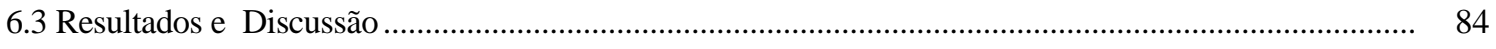

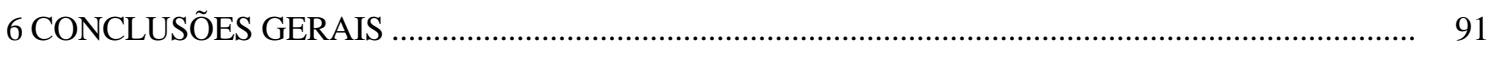

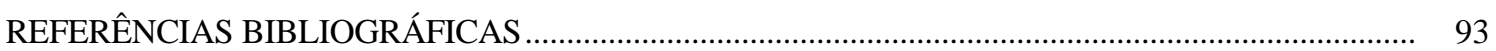




\title{
DIVERSIDADE DE Xanthomonas SPP. ASSOCIADAS À MANCHA-BACTERIANA EM TOMATEIRO PARA PROCESSAMENTO INDUSTRIAL NO BRASIL
}

\author{
Autora: ALICE MARIA QUEZADO DUVAL \\ Orientador: Prof. Dr. LUIS EDUARDO ARANHA CAMARGO
}

\section{RESUMO}

A mancha-bacteriana, causada por bactérias do gênero Xanthomonas, é uma das doenças mais importantes da cultura do tomate (Lycopersicon esculentum Mill.) para processamento industrial no Brasil. A etiologia dessa doença é complexa e a ocorrência das espécies envolvidas nas epidemias em lavouras da cultura no país é notavelmente pouco conhecida. Os objetivos desta tese foram identificar as espécies/grupos genéticos e as raças presentes em campos comerciais nas macro-regiões produtoras do BrasilCentral e Nordeste, determinar a sensibilidade in vitro de isolados ao cobre e aos antibióticos estreptomicina e oxitetraciclina. Inicialmente, 447 isolados foram analisados quanto aos perfis de eletroforese de campo pulsado (PFGE) e quanto às atividades amidolítica e pectolítica. Após identificação dos haplótipos PFGE, grupos de isolados foram caracterizados através de testes de patogenicidade em tomateiro e pimentão, presença das proteínas $\alpha$ ou $\beta$, utilização de fontes de carbono, sensibilidade in vitro ao cobre, estreptomicina e oxitetraciclina, reação provocada em hospedeiras diferenciais de 
tomateiro e Capsicum e presença dos genes de avirulência avrRxv e avrXv3. As análises da diversidade foram efetuadas a partir de índices de diversidade de Nei e pela análise de variância molecular (AMOVA). As três espécies de Xanthomonas relatadas na literatura como associadas à mancha-bacteriana em tomateiro, foram detectadas nos campos comerciais amostrados. Porém, no Brasil-Central as epidemias foram causadas principalmente por ' $X$. gardneri', enquanto que no Nordeste, exclusivamente por $X$. axonopodis pv. vesicatoria. Este é o primeiro relato de epidemias causadas por ' $X$. gardneri' no mundo. A diversidade haplotípica foi baixa dentro de populações. Não obstante, menor diversidade intra-em variedades híbridas importadas do que PA nacionais. Da mesma forma, populações do Brasil-Central foram menos variáveis do que as do Nordeste. Esses fatos se explicam pela predominância em variedades PA nacionais e macro-região Nordeste de isolados pertencentes ao grupo PFGE 1, que apresentou-se mais polimórfico, em oposição aos grupos 3 e 4, menos variáveis que predominaram em variedades híbridas e no Brasil-Central. A maior proporção da variação total, por sua vez, foi atribuída ao componente inter-populacional, tanto para macro-regiões como para tipos de variedade. No entanto, considerável variação genética foi atribuída ao efeito da macro-geografia $(30,6 \%)$ ou tipo de variedade $(24,4 \%)$. Em relação às raças, relatou-se a ocorrência no país pela primeira vez das raças T3 e T1P8, no Nordeste e T2P7 e T2P8, no Brasil-Central. Esse fato indica que as resistências derivadas de 'NIL 216', L. pennelli e 'Hawaii 7998' são promissoras para o Nordeste. Quanto à sensibilidade aos agentes de controle químico, não foram encontrados isolados resistentes à oxitetraciclina $(25 \mu \mathrm{g} / \mathrm{ml})$. No entanto, foram encontrados isolados resistentes ao cobre $(50 \mu \mathrm{l} / \mathrm{ml})$ e à estreptomicina $(25 \mu \mathrm{g} / \mathrm{ml})$ em alta freqüência principalmente entre isolados de ' $X$. gardneri', o que explica a baixa eficiência do controle químico muitas vezes observada no campo. Este trabalho representa o primeiro relato sobre a composição populacional em larga escala de Xanthomonas spp. associadas à mancha-bacteriana em tomateiro rasteiro no país. 


\title{
DIVERSITY OF Xanthomonas SPP. ASSOCIATED WITH BACTERIAL SPOT OF PROCESSING TOMATOES IN BRAZIL
}

\author{
Author: ALICE MARIA QUEZADO DUVAL \\ Adviser: Prof. Dr. LUIS EDUARDO ARANHA CAMARGO
}

\section{SUMMARY}

Bacterial spot caused by bacteria of the genus Xanthomonas is one of the most important diseases of tomatoes for processing (Lycopersicon esculentum Mill.) in Brazil. The etiology of this disease is complex and there is notable lack of knowledge about the species involved in epidemics on this crop in Brazil. The objectives of this thesis were to identify the species/genetic groups, as well as races present in commercial fields in in Central and Northeastern Brazil, to determine the in vitro sensitivity of strains to copper and to streptomycin and oxytetracyclin. Initially, 447 strains were characterized according to their pulsed-field electrophoresis haplotypes and also for their amilolytic and pectolytic activities. After these analyses, selected strains were then tested for their pathogenicity on tomato and pepper, for the presence of $\alpha$ or $\beta$ proteins, utilization of carbon sources, in vitro sensitivity to copper, streptomycin and oxitetracyclin, reactions on differential tomato and pepper hosts and presence of the avirulence genes avrRxv and $a v r X v 3$. Diversity analysis of bacterial populations were done with Nei's diversity index 
and analysis of molecular variance (AMOVA). The three Xanthomonas species reported in the literature as associated with tomato bacterial spot, were detected in the sampled fields. However, the populations from Central Brazil were mainly composed by ' $X$. gardneri', whereas in the Northeast, $X$. axonopodis pv. vesicatoria was the only species found. The haplotipic diversity was considerably low within populations. However, intra-populational diversity was lower among imported hybrids than among national OP varieties. Similarly, populations from Central-Brazil were less variable than the ones from Northeast. These facts are explained by the predominance of strains from the more variable PFGE group 1 in OP varieties and in the Northeast region as opposed to the less variable groups 3 and 4 which predominated in hybrids and in Central Brazil. The greatest proportion of genetic in both analyses. However, considerable genetic variation was conferred by macrogeography (30.6\%) or type of variety $(24.4 \%)$ effects. Inoculation of selected strains on differential cultivars of pepper and tomato revealed, for the first time in Brazil, the occurrence of races T3 and T1P7, in the Northeast and $\mathrm{T} 2 \mathrm{P} 7$ and $\mathrm{T} 2 \mathrm{P} 8$, in Central Brazil. This fact indicates the promissing use of derived resistances from 'NIL 216', L. pennelli and 'Hawaii 7998' for the Northeast. No strains were resistant to oxitetracyclin $(25 \mu \mathrm{g} / \mathrm{ml})$ but a high frequency of strains resistant both to copper $(50 \mu \mathrm{l} / \mathrm{ml})$ and streptomycin $(25 \mu \mathrm{g} / \mathrm{ml})$ was found within ' $X$. gardneri'. This fact may explain the low efficiency of chemical control sometimes observed in the field. This work represents the first report about a large scale populational composition Xanthomonas spp. associated with processing tomatoes bacterial spot in Brazil. 


\section{INTRODUÇÃ̃O}

A cultura do tomate (Lycopersicon esculentum Mill.) rasteiro para processamento industrial foi introduzida no Brasil no início do século XX no estado de Pernambuco. A partir da década de 50, porém, a produção brasileira se consolidou, inicialmente no estado de São Paulo, onde foram implantadas as primeiras agroindústrias de processamento (Silva \& Giordano, 2000). Atualmente, o cultivo do tomate rasteiro e o seu processamento estão concentrados em três principais macroregiões que compreendem o estado de São Paulo, a mais tradicional; os estados de Pernambuco e Bahia (no Vale do Rio São Francisco), e os estados de Goiás (região de Cerrado) e Minas Gerais (Triângulo Mineiro). Nesta terceira região, onde as condições edafoclimáticas são ideais tanto para o cultivo extensivo irrigado como para a mecanização, observa-se uma grande expansão da cultura, que tem alcançado produtividades médias superiores à média nacional (Barbosa, 1997; Silva \& Giordano, 2000).

A mancha-bacteriana, causada por bactérias do gênero Xanthomonas (Dowson), é uma das doenças mais importantes do tomateiro para processamento industrial no Brasil, com ocorrências freqüentes em áreas irrigadas por aspersão tradicional ou por pivô-central, independentes do estádio da cultura (Barbosa, 1997). As perdas devido a esta doença são resultantes da redução da produção em decorrência direta dos sintomas e do custo dos produtos químicos utilizados em seu controle, notadamente fungicidas cúpricos e antibióticos agrícolas. Além de aumentar o custo de produção, o controle químico é de baixa eficiência (Goode \& Sasser, 1980; Maringoni et al., 1986; QuezadoSoares \& Lopes, 1999). 
A ineficiência do controle químico e a inexistência de cultivares com altos níveis de resistência genética à mancha-bacteriana são atribuídas à grande variabilidade dos agentes causadores da doença (Bouzar et al., 1999; Goode \& Sasser, 1980). Por sete décadas, estes agentes foram identificados como pertencentes a uma única espécie, denominada Xanthomonas campestris pv. vesicatoria (Doidge) Dye (Bradbury, 1986). No entanto, estudos recentes evidenciam que a mancha-bacteriana é, na verdade, uma doença que pode ser causada por três espécies: $X$. axonopodis pv. vesicatoria (Starr and Garces) emend. Vauterin et al., $X$. vesicatoria (ex Doidge) Vauterin et al. e $X$. 'gardneri', cuja taxonomia ainda está indefinida (Jones et al., 1998a; Vauterin et al., 1995).

O conhecimento da diversidade fenotípica e genética do complexo etiológico da mancha-bacteriana é fundamental para o desenvolvimento de técnicas de indexação de material propagativo (sementes e mudas), avaliação da eficiência do controle químico, bem como para o desenvolvimento de cultivares resistentes. O último estudo conduzido no Brasil nesse sentido foi realizado há mais de 15 anos, utilizando-se apenas 16 isolados (Bongiolo Neto et al., 1986). Desde então, surgiram novas áreas de produção de tomate para processamento industrial, com crescente utilização de sementes híbridas importadas (Barbosa, 1997).

O objetivo geral deste trabalho foi o de realizar um estudo abrangente de caracterização do complexo causador da mancha-bacteriana, a partir de isolados pertencentes à coleção de trabalho da Embrapa Hortaliças, coletados em campos de tomate para processamento industrial. Seus objetivos específicos foram: 1) determinar as espécies presentes em campos comercias nas macro-regiões Brasil-Central e Nordeste com base em análises genéticas e fenotípicas (capítulos 3 e 4); 2) avaliar comparativamente a diversidade populacional das espécies encontradas (capítulo 4); 3) determinar as raças presentes nesses campos com base em reações de variedades diferenciais de tomate e de pimentão (capítulo 5) e 4) determinar a sensibilidade in vitro ao cobre e aos antibióticos estreptomicina e oxitetraciclina (capítulo 6). 


\section{REVISÃO DE LITERATURA}

\subsection{Importância da cultura}

No cenário mundial, a produção de tomate para processamento industrial (Lycopersicon esculentum Mill.), ou tomateiro rasteiro, tem variado entre 24,1 a 29,6 milhões de toneladas nos últimos dez anos. Os Estados Unidos da América despontam como os maiores produtores, com 9 milhões de toneladas em 1997, sendo 8,5 milhões produzidos no estado da Califórnia. No Brasil, em 1998, foram cultivados mais de 22.000 ha, resultando em uma produção de 1,2 milhões de toneladas (Silva \& Giordano, 2000).

A agroindústria brasileira tem capacidade instalada para processar 17.080 toneladas diárias, em 26 unidades processadoras distribuídas nos estados do Ceará, Pernambuco, Bahia, Goiás, Minas Gerais e São Paulo (Silva \& Giordano, 2000). A expansão do mercado interno de produto processado (polpas, molhos, etc.) tem atraído o capital estrangeiro com a participação dos grupos Gessy-Léver (Cica), Parmalat (Etti), Cirio-Bombril (Peixe, MS Alimentos), Iansafruit (SóFruta) (Silva \& Giordano, 2000) e, mais recentemente, a americana BestFoods (Arisco) (Veiga Filho, 2000).

A produção nacional concentra-se em três principais regiões edafoclimáticas: 1 . Centro-Sul, no estado de São Paulo; 2. Nordeste, no vale do São Francisco nos estados da Bahia e Pernambuco e 3. Centro-Oeste, nos estados de Goiás e Minas Gerais (Barbosa, 1997). Nesta última região, a área de cultivo aumentou de 5.000 ha, em 1991, para 11.000 ha, em 1998, com uma produtividade média de 67 ton/ha, superior à média nacional. Baixa umidade relativa do ar, temperaturas amenas durante os meses de março a setembro e áreas de topografia plana, favoráveis a mecanização e ao uso de sistemas de irrigação do tipo pivô-central, são fatores que vêm contribuindo para a expansão do 
cultivo nessa nova fronteira agrícola. Por outro lado, redução substancial do cultivo tem sido observada nas tradicionais regiões do Nordeste e do estado de São Paulo, que vem sendo acompanhada pelo deslocamento dos parques industriais para o Centro-Oeste (Silva \& Giordano, 2000). Problemas fitossanitários, em decorrência do clima e desvio da produção para o comércio de frutos in natura, são as principais causas desta retração (Melo, 1993).

\subsection{Histórico da etiologia da mancha-bacteriana}

A mancha-bacteriana do tomateiro foi observada primeiramente em 1914 na África do Sul, e descrita por Doidge em 1920, com o nome de cancro do tomate (Jones et al., 1998a). No entanto, a designação pela qual a síndrome é mais conhecida atualmente, mancha-bacteriana ("bacterial spot”), foi instituída por Gardner \& Kendrick (1921), quando a descreveram ocorrendo nos Estados Unidos na mesma época (Jones et al., 1998a). Os agentes causadores das duas supostas síndromes, cancro do tomate e mancha-bacteriana, foram identificados em 1921, respectivamente, como Bacterium vesicatorium n. sp., por Doidge e como B. exitiosum n. sp., por Gardner \& Kendrick (Bradbury, 1986; Jones et al., 1998a). Gardner \& Kendrick (1923), após estudos comparativos, concluíram tratar-se de uma única espécie de bactéria, que era capaz de infectar plantas de tomate e de pimentão, dando prioridade ao nome Bacterium vesicatorium Doidge.

A denominação do agente causador da mancha-bacteriana ainda passaria de $B$. vesicatorium para Pseudomonas vesicatoria em 1925, para Phytomonas vesicatoria em 1930 e para Xanthomonas vesicatoria em 1939 (Bradbury, 1986; Jones et al., 1998a). Com a redução do número de espécies do gênero Xanthomonas para cinco, por Dye \& Lelliot em 1974, o agente causador da mancha-bacteriana em plantas de tomate e pimentão foi reclassificado em 1978 como um patovar da espécie X. campestris por Young et al., com a denominação de Xanthomonas campestris pv. vesicatoria Dowson (Dye) (Sahin, 1997).

Xanthomonas campestris pv. vesicatoria é descrita como uma bactéria baciliforme $(0,7-1,0 \times 2,0-2,4 \mu \mathrm{m})$, gram negativa, aeróbia e móvel através de um 
flagelo polar (Jones, 1997). De acordo com a moderna classificação filogenética de bactérias, baseada principalmente em comparações de seqüências nucleotídicas, principalmente do rRNA 16S, o gênero Xanthomonas pertence ao filo Proteoacteria, classe "Gammaproteobacteria" (Classe III), ordem "Xanthomonadales" (Ordem II) e família "Xanthomonadaceae" (Garrity \& Holt, 2000). Possui ainda as características marcantes de formar colônias amarelas em meio Nutriente Ágar e de produzir o pigmento xantomonadina (Bradbury, 1986; Stall, 1993).

O patógeno, porém, têm se mostrado bastante variável em suas características fenotípicas e genotípicas, sendo possível a distinção de até quatro grupos ("A", "B", "C" e "D"), conforme será tratado oportunamente nesta revisão. Em virtude dessas diferenças, Vauterin et al. (1995) reclassificaram várias espécies do gênero Xanthomonas e subdividiram $X$. campestris pv. vesicatoria em duas espécies: $X$. axonopodis pv. vesicatoria e $X$. vesicatoria. A primeira espécie abrangia, na época, o grupo "A", e $X$. vesicatoria, o grupo "B”. A denominação dada a essas espécies tem sido motivo de controvérsias (Schaad et al., 2000; Young et al., 2001), sendo que Schaad et al. (2000) consideram que o grupo "B" deveria ser denominado $X$. exitiosa e o grupo “A” de $X$. vesicatoria.

Além disso, 'X. gardneri' também está associada à mancha-bacteriana do tomate e pimentão (Jones et al., 1998a). Em 1957, esta bactéria foi identificada pela primeira vez na Iugoslávia como 'P. gardneri' (Šutic, 1957). A espécie, no entanto, foi considerada sinônimo de $X$. vesicatoria por Dye (1966), pois não podia ser distinguida da mesma através dos testes fisiológicos e de patogenicidade. No entanto, Hildebrand et al. (1990), por hibridização de DNA, verificou que 'X.gardneri' estava mais relacionada às espécies $X$. campestris pv. carotae, X. campestris pv. pelargonii e X. campestris pv. taraxaci e que $X$. campestris pv. vesicatoria representava um grupo à parte. Apesar de ainda não ter sido validada como espécie, estudos recentes com isolados de Xanthomonas spp. patogênicos às hospedeiras tomate e pimentão vêm confirmando que 'X.gardneri' (=grupo “D”) é uma entidade taxonômica distinta de X. vesicatoria (=grupo “B”) e X. axonopodis pv. vesicatoria (=grupos “A" e "C") (Bouzar et al., 1994b; Bouzar et al., 1999; Jones et al., 2000). 


\subsection{Sintomatologia e importância da doença}

Sintomas da mancha-bacteriana ocorrem em toda a parte aérea da planta, podendo se manifestar em qualquer estádio da cultura (Gitaitis et al., 1992). Nas folhas, os primeiros sintomas aparecem na forma de pequenas áreas encharcadas de formato irregular, porém, com bordos definidos, que se tornam deprimidas, passando de uma coloração amarelada ou verde-clara para marrom-escura até a necrose dos tecidos (Goode \& Sasser, 1980).

Distintamente do que ocorre em plantas de pimentão, em tomateiro a manchabacteriana não leva à queda de folhas. Porém, com o coalescimento das manchas necróticas foliares, verifica-se o secamento e destruição da folhagem a partir da parte baixeira das plantas. Neste caso, é comum o aparecimento nos frutos de sintomas de queima de sol (Lopes \& Quezado-Soares, 1997). Nos frutos, as lesões iniciam-se na forma de pequenas áreas encharcadas a amareladas, que se tornam marrom-acinzentadas e de textura áspera (Jones, 1997). Estas lesões tendem a ser deprimidas no centro e elevadas nas margens, variando entre 2 a $10 \mathrm{~mm}$ de diâmetro, podendo ser circundada por um estreito halo amarelado a esbranquiçado (Goode \& Sasser, 1980). A ocorrência da doença durante a floração causa queda de flores, resultando na redução da produção (Lopes \& Quezado-Soares, 1997).

De acordo com Rodrigues Neto et al. (1984), a mancha-bacteriana em tomateiro foi relatada a primeira vez no Brasil em 1959 por Ciccarone \& Dowson, em municípios do estado de São Paulo. É uma das doenças mais importantes e destrutivas do tomateiro para processamento industrial no país, com ocorrências freqüentes nas três macroregiões de produção (Barbosa, 1997).

As perdas devido à mancha-bacteriana são resultantes da redução da produção em decorrência direta dos sintomas da doença e do custo dos produtos químicos utilizados como estratégia de controle, notadamente fungicidas cúpricos e antibióticos agrícolas (Goode \& Sasser, 1980). Redução em até 52\% da produção foi observada em condições experimentais de campo (Quezado-Soares et al., 1998b).

Outros aspectos que intensificam a importância da mancha-bacteriana para a cultura do tomateiro para processamento industrial podem ser citados, tais como: 
eficiência variável do controle químico, ausência de fontes de resistência adequada, rápida disseminação em condições favoráveis de altas temperaturas $\left(24-30^{\circ} \mathrm{C}\right) \mathrm{e}$ precipitação e disseminação a longas distâncias por sementes contaminadas (Goode \& Sasser, 1980; Jones, 1997). Além de servir como fonte de inóculo, sementes representam um meio para sobrevivência da bactéria por longos períodos (Bashan et al., 1982).

\subsection{Controle químico}

O controle químico das bacterioses tem sido feito com antibióticos agrícolas, tendo como princípios ativos a estreptomicina ou a oxitetraciclina, e com produtos cúpricos (Quezado-Soares \& Lopes, 1999; McManus, \& Stockwell, 2002). Vários relatos, no entanto, demonstram a baixa eficiência da estreptomicina e dos cúpricos para o controle da mancha-bacteriana (Goode \& Sasser, 1980; Marco \& Stall, 1983; Maringoni et al., 1986; Quezado-Soares \& Lopes, 1999). O aparecimento de indivíduos resistentes nas populações bacterianas é apontado como a principal causa dessa ineficiência (Bouzar et al., 1999; Marco \& Stall, 1983; Minsavage et al. 1990; Ritchie \& Dittapongpitch, 1991; Sahin, 1997; Stall \& Thayer, 1962; Thayer \& Stall, 1961).

Diferenças em sensibilidade à estreptomicina entre isolados de Xanthomonas campestris pv. vesicatoria foram primeiramente observadas na Flórida, EUA, no início dos anos 60 (Stall \& Thayer, 1962; Thayer \& Stall, 1961). Atualmente, devido a diversos fatores ligados ao custo, eficiência, proteção ambiental e saúde humana, diferentemente do Brasil, o uso de antibióticos agrícolas nos EUA é restrito, sendo permitido apenas para o controle da Erwinia amylovora em pomares de maçã e pêra, bacterioses em plantas ornamentais e na produção de mudas (McManus \& Stockwell, 2002).

Igualmente na Flórida ocorreu o primeiro relato, em 1983, da resistência ao cobre em Xanthomonas campestris pv. vesicatoria (Marco \& Stall, 1983). No entanto, a resistência ao metal deveria estar presente nas populações bacterianas em épocas anteriores, já que isolados obtidos em 1968 também mostraram-se resistentes (Cooksey, 1990). Tanto em bactérias fitopatogênicas como em saprófitas, a resistência ao cobre pode ser mediada por genes encontrados em plasmídeos ou em DNA cromossômico 
(Cooksey, 1990; Cooksey et al., 1990; Lee et al., 1994; Minsavage et al., 1990; Voloudakis et al., 1993). Homologia determinada por hibridizações e similaridades de sequência nucleotídicas de genes de resistência ao metal têm sido detectadas entre patovares do gênero Xanthomonas, inclusive $X$. campestris pv. vesicatoria, e de $P$. syringae, incluindo P. syringae pv. tomato, sugerindo que estes genes tenham um ancestral evolutivo comum e que possam ter sido adquiridos por transferência horizontal (Lee et al., 1994; Voloudakis et al., 1993).

\subsection{Interações com a hospedeira e resistência varietal}

Inicialmente, acreditava-se que todos os isolados de Xanthomonas campestris pv. vesicatoria poderiam infectar plantas de tomate e de pimentão (Gardner \& Kendrick, 1923). Porém, esta característica tem se mostrado complexa. Alguns isolados são patogênicos apenas à tomate, outros apenas à pimentão, e outros às duas espécies (Bouzar et al., 1994b). Canteros et al. (1991) clonaram um gene, localizado em plasmídeo, de um isolado patogênico apenas ao pimentão, o gene avrBsP. Quando transferido para um isolado patogênico à tomate, este gene se expressa na forma de avirulência a esta espécie hospedeira.

Para cada espécie hospedeira existem ainda raças fisiológicas do patógeno. Até o presente, já foram descritas três raças que atacam tomate (Wang et al., 1990; Jones et al., 1995) (Tabela 1) e onze raças que atacam pimentão (Kousik \& Ritchie, 1995; Romero et al., 2002; Sahin \& Miller, 1995; Sahin \& Miller, 1997; Sahin, 1997), ocorrendo diferentes combinações entre as raças de tomate e as raças de pimentão que infectam as duas hospedeiras (Bouzar et al., 1994b; Jones et al., 1995; Jones et al., 1998b).

Em relação ao tomate, isolados da raça $\mathrm{T} 1$ são portadores do gene de avirulência avrRxv (Whalen et al., 1993), que interage com pelo menos três genes de resistência não-dominantes (rx1, rx2 e rx3) do genótipo 'Hawaii 7998' (Wang et al., 1994; Yu et al., 1995). Como resultado, ocorre a raça T2, representada primeiramente

pelo isolado Xv56, proveniente do Brasil, e que é capaz de suplantar a resistência de 'Hawaii 7998' (Wang et al., 1990), não existem fontes conhecidas de resistência 
qualitativa (Scott et al., 1997). Isolados da raça T3 são portadores dos genes de avirulência $a v r X v 3$ e $a v r X v 4$ (Minsavage et al., 1996; Astua-Monge et al., 2000a; AstuaMonge et al., 2000b), que interage, respectivamente, com o gene de resistência $X v 3$ presente em vários genótipos e Xv4, presente em Lycopersicon pennellii (Coor.) D’Arcy (Astua-Monge et al., 2000a). Uma reação de hipersensibilidade também é desencadeada (Jones et al., 1998a; Scott et al., 1995). Isolados da raça T1 têm sido agrupados no grupo "A"; da raça T2, no grupo "B", e da raça T3, no grupo "C" (Jones et al., 1998a). Jones et al. (1998a) demonstraram a natureza competitiva da raça T3 na presença da raça T1, explicando a sua prevalência em campos de tomate na Flórida, EUA, desde que foi inicialmente constatada em 1991. A ocorrência das raças T1 e T2 já foi relatada no Brasil (Bouzar et al., 1994b; Quezado-Soares et al., 1997).

Tabela 1. Reações diferenciais de genótipos de tomate (Lycopersicon spp.) às raças de Xanthomonas spp. associadas à mancha-bacteriana.

\begin{tabular}{|c|c|c|c|}
\hline \multirow[t]{2}{*}{ Raças } & \multicolumn{3}{|c|}{ Genótipos diferenciais } \\
\hline & Walter & Hawaii 7998 & Hawaii $7981^{1}$ \\
\hline $\mathrm{T} 1$ & $\mathrm{~S}^{2}$ & $\mathrm{RH}^{2}$ & $\mathrm{~S}$ \\
\hline $\mathrm{T} 2$ & $\mathrm{~S}$ & $\mathrm{~S}$ & $\mathrm{~S}$ \\
\hline $\mathrm{T} 3$ & $\mathrm{~S}$ & S & $\mathrm{RH}$ \\
\hline
\end{tabular}

1. Lycopersicon pimpinellifolium (Jusl.) Mill. PI 128216 e PI 126932 mostram a mesma reação.

2. Reações observadas após infiltração de suspensão bacteriana $\left(\geq 10^{8} \mathrm{ufc} / \mathrm{mL}\right) \mathrm{S}$ : reação de suscetibilidade (3-5 dias após a infiltração); RH: reação de hipersensibilidade em até 48hs.

Fonte: Jones et al., 1998a.

No Brasil, um levantamento realizado por Bongiolo Neto et al. (1986), onde foram coletados 49 isolados em diferentes regiões, sendo 16 destes provenientes de plantas de tomate, indicou a presença de cinco diferentes patotipos. As variedades diferenciais utilizadas foram Early Calwonder e linhagem 10R (pimentão) e tomate cv. Grothens Globe, como sugerido por Cook \& Stall (1969). No entanto, uma correlação entre esses patotipos e os grupos/espécies propostos atualmente não pôde ser feita já que 
outras hospedeiras diferenciais foram incluídas posteriormente para a distinção das raças (Bouzar et al., 1994b; Jones et al., 1995; Kousik \& Ritchie, 1995; Sahin \& Miller, 1995).

Apesar de alguns genótipos terem sido identificados como resistentes por apresentarem uma reação de hipersensibilidade às raças T1 e T3 do patógeno (Scott \& Jones, 1986; Jones et al., 1995), ainda não existem variedades disponíveis no mercado com resistência à mancha-bacteriana Stall (1997). Resistência parcial e não-específica, no entanto, tem sido identificada (Laterrot, 1997; Quezado-Soares et al., 1998b; Scott \& Jones, 1986; Scott et al., 1997).

\subsection{Caracterização de Xanthomonas spp. associadas à mancha-bacteriana}

Como dito anteriormente, por mais de 70 anos acreditou-se que a manchabacteriana era causada por uma única espécie de patógeno, classicamente identificada como Xanthomonas campestris pv. vesicatoria (Jones et al., 1998a). Vários estudos têm sido realizados no intuito de esclarecer a etiologia desta doença e as relações filogenéticas entre as isolados através de suas características fenotípicas e genotípicas.

\subsubsection{Caracterização fenotípica}

As principais características que norteiam a distinção entre os grupos de Xanthomonas spp. que causam a mancha-bacteriana ("A", "B", "C" e "D”) e que levaram à reclassificação da espécie $X$. campestris pv. vesicatoria, são apresentadas na Tabela 2.

A capacidade de hidrolizar amido (atividade amidolítica) foi uma das primeiras características fenotípicas que se mostrou variável entre os isolados de Xanthomonas spp. associados à mancha-bacteriana em tomate e pimentão (Burkholder \& Li, 1941; Doidge, 1921 e Gardner \& Kendrick, 1921, citados por Jones et al., 1998a). Esta característica foi associada à atividade pectolítica por Stall et al. (1994), de modo que isolados que possuem atividade amidolítica também possuem a pectolítica. A atividade pectolílica é resultado da ação de uma única enzima pectato-liase (Beaulieu et al., 1991). Isolados do grupo "B" têm se mostrado capazes de hidrolizar amido e produzir pectato 
liase, enquanto alguns isolados do grupo "A", também possuem essas atividades e passaram a constituir um subgrupo (“A2" de Jones et al., 1998a = “A1” de Jones et al., 2000) (Tabela 1). Estes isolados foram encontrados inicialmente no México (Bouzar et al., 1996).

Tabela 2. Características fenotípicas utilizadas para a distinção dos grupos de Xanthomonas spp. que causam mancha-bacteriana em tomate e pimentão

\begin{tabular}{|c|c|c|c|c|c|}
\hline \multirow{2}{*}{$\begin{array}{l}\text { Característica } \\
\text { fenotípica }^{1}\end{array}$} & \multicolumn{5}{|c|}{ Grupo $^{2}$} \\
\hline & A & A1 & $\mathrm{B}$ & $\mathrm{C}$ & $\mathrm{D}$ \\
\hline Mabs & 1,21 & 1,21 & 8,15 & 30 & 8 \\
\hline Proteína específica & $32 \mathrm{kDa}$ & $25 \mathrm{kDa}$ & $27 \mathrm{kDa}$ & $27 \mathrm{kDa}$ & $27 \mathrm{kDa}$ \\
\hline Atividade pectolítica & - & + & + & + & - \\
\hline Atividade amidolítica & - & + & + & + & - \\
\hline Cis-asconitato & 100 & 100 & 0 & s.i. & 14 \\
\hline Gentiobiose & 100 & 0 & 100 & s.i. & 0 \\
\hline Raças $T^{3}$ & T1, T1P0-6 & $\mathrm{T} 1 \mathrm{P} 2$ & $\mathrm{~T} 2, \mathrm{~T} 2 \mathrm{P} 0-6$ & $\mathrm{~T} 3$ & $\mathrm{~T} 2 \mathrm{P} 1$ \\
\hline
\end{tabular}

1. Mabs: anticorpos monoclonais que reagem com as isolados em teste sorológico de Elisa; proteína específica: peso em kDa da banda detectada por SDS-PAGE; atividades amidolítica e pectolítica in vitro (-: atividade negativa até 5 dias; +: atividade positiva); fontes de carbono cis-asconitato e gentiobiose: o número refere-se à porcentagem de isolados do estudo de Bouzar et al. (1999) capazes de utilizar gentiobiose e cis-asconitato; raças T: raças patogênicas à tomate descritas em literatura (Bouzar et al., 1994b; Bouzar et al., 1999; Jones et al., 1998a; O'Garro, 1998; O'Garro et al., 1999; Sahin, 1997; Sahin \& Miller, 1996; Stall et al., 1994); s.i.i. sem informação.

2. Grupos A, A1 e C são variantes da espécie X. axonopodis pv. vesicatoria; grupo B, X. vesicatoria. Grupo D: 'X. gardneri' (Jones et al., 2000; Vauterin et al., 1995).

3. P0-6: combinações de T com sete raças P (P0, P1, P2, P3, P4, P5 e P6); “-“: raças P encontradas na combinação. Algumas raças P1 e P3 poderão vir a ser reclassificadas em P7 e P8, respectivamente, de acordo com Sahin (1997).

Juntamente às atividades amidolíticas e pectolíticas (Bouzar et al., 1994a; O’Garro, 1998; Stall et al., 1994), outras características fenotípicas estão sendo empregadas em estudos de caracterização e diversidade, tais como: reações a anticorpos monoclonais (Bouzar et al., 1994b; Jones et al., 2000; Sahin \& Miller, 1996; Stall et al., 1994), perfis de proteínas totais (Vauterin et al., 1991) e expressão de bandas específicas de proteínas totais detectadas através de eletroforese em gel de poliacrilamida (SDS- 
PAGE) (Bouzar et al., 1994a; Bouzar et al., 1999; O’Garro, 1998; O’Garro et al., 1999); utilização de carbono (Bouzar et al, 1994b; Bouzar et al., 1999; O'Garro et al., 1999; Stall et al., 1994); composição e conteúdo de ácidos graxos (Bouzar et al., 1994b); sensibilidade ao cobre e ao antibiótico estreptomicina (Bouzar et al., 1999; Buonaurio et al., 1994; O’Garro, 1998; Sahin \& Miller, 1996); atividades a diversas enzimas (Jones et al., 2000); reação com bacteriófagos (Bouzar et al., 1999), e características de patogenicidade (Bouzar et al., 1999; Bouzar et al., 1994b; Buonaurio et al., 1994; O’Garro, 1998; O’Garro et al., 1999; Sahin \& Miller, 1996).

\subsubsection{Caracterização genotípica}

$\mathrm{O}$ advento da biologia molecular tem resultado em mudanças significativas nos enfoques usados para caracterizar e identificar fitopatógenos. Lows et al. (1999) consideram que métodos baseados na análise de ácidos nucléicos são mais estáveis, refletindo mais precisamente as relações genéticas entre os microorganismos quando comparados às várias características fenotípicas comumente empregadas (serologia, características bioquímicas, composição de ácidos graxos, utilização de substratos, etc.).

A caracterização genotípica de Xanthomonas spp. que causam manchabacteriana em plantas de tomate e/ou de pimentão tem sido realizada tanto empregandose métodos que dependem da amplificação por PCR ("Polymerase Chain Reaction"), como através de análises genômicas que independem da PCR (Lows et al., 1999).

\subsubsection{Caracterização por análises genômicas independentes da PCR}

O grau de homologia cromossômica, determinado pela análise da hidridização DNA-DNA (reassociação cinética DNA-DNA), tem sido considerado o principal fator que determina a definição de espécie bacteriana (Louws et al., 1999; Vauterin et al., 1995; Wayne et al., 1987). Hildebrand et al. (1990), através de hibridização entre vários patovares de Xanthomonas campestris e 'X. gardneri', confirmaram o posicionamento desta última espécie no gênero Xanthomonas, bem como sua distinção da até então descrita X. campestris pv. vesicatoria. Vauterin (1991) e Stall et al. (1994) mostraram 
evidências para a subdivisão deste patovar em dois subgrupos geneticamente distintos (grupo "A" e grupo "B"). Os níveis de hibridização entre isolados do grupo "A" e grupo " $\mathrm{B}$ " variaram de 0 a $46 \%$, enquanto a variação entre isolados do grupo " $\mathrm{A}$ " e o isoladotipo deste grupo (75-3) e entre isolados "B" e o isolado-tipo do grupo (Xv56), foi superior a 70\% (Stall et al., 1994). Posteriormente, Vauterin et. al. (1995) reclassificaram a espécie em $X$. axonopodis pv. vesicatoria (= grupo "A") e $X$. vesicatoria (= grupo "B').

Jones et al. (2000) estudaram as relações entre ' $X$. gardneri' e patovares de $X$. campestris, isolados do grupo "B" e do grupo "A", sustentando as evidências indicadas por Hildebrand et al. (1990). A relação estreita entre o subgrupo "A1" (= subgrupo "A2" em Jones et al., 1998a, Am+ e Pec+) e demais isolados do grupo "A" (= subgrupo "A1" em Jones et al., 1998a, Am- e Pec-) também foi confirmada, justificando o posicionamento dos dois em uma mesma espécie (Jones et al., 2000). O grupo "C", até o presente representado pela raças T3 (Tabela 1), mostrou-se distinto de "A" por hibridização, mas foi considerado próximo o suficiente para pertencer à mesma espécie. Os autores propõem que isolados deste grupo sejam posicionadas em uma subspécie de $X$. axonopodis pv. vesicatoria.

Outros métodos empregados para a análise do DNA genômico incluem a caracterização dos padrões de plasmídios (Canteros et al., 1995) e a análise dos padrões de fragmentos resultantes da digestão do DNA total ou de plasmídeos com enzimas de restrição ("Restriction Enzyme Analysis", REA) ou após hibridização com sondas genômicas específicas ("Restriction Fragment Length Polymorphism", RFLP) (Louws et al., 1999). Um método derivado consiste da digestão com enzimas que reconhecem sítios de restrição raros, resultando na produção de fragmentos grandes que são separados por eletroforese em campo magnético invertido ("Field Inversion Gel Electrophoresis", FIGE) ou em campo pulsado ("Pulsed Field Gel Electrophoresis", PFGE) (Lows et al., 1999).

Cooksey \& Graham (1989) utilizaram a técnica FIGE para comparar isolados de patovares de Pseudomonas syringae e de Xanthomonas campestris, incluindo $X$. campestris pv. vesicatoria. Os autores indicaram que os padrões obtidos poderiam ser 
numericamente analisados através do cálculo de coeficientes de dissimilaridade e análises de agrupamento. A técnica PFGE também tem sido empregada para o estudo da diversidade e das relações filogenéticas de bactérias fitopatogênicas, tais como: Erwinia amylovora (Zhang \& Geider, 1997), Pantoea stewartii subsp. stewartii (Coplin et al., 2002), Xanthomonas campestris que causam doenças em citros (Egel et al., 1991) e Xanthomonas spp. associadas à mancha-bacteriana de tomate e pimentão (Bouzar et al., 1996; Jones et al., 2000; Stall et al., 1994). Para este complexo patossistema, os resultados obtidos pelas análises de PFGE corroboraram com as proposições taxonômicas feitas por Vauterin et al. (1995). Em trabalho preliminar, Quezado-Soares et al. (1998a) empregaram essa técnica para classificar isolados coletados em campos de tomate e de pimentão para industrialização quanto ao grupo sensu Stall et al. (1994).

\subsubsection{Caracterização por análises genômicas dependentes da PCR e por comparação de sequências nucleotídicas}

As várias técnicas que vêm sendo desenvolvidas com base em PCR, com promissora aplicação para estudos de diversidade, desenvolvimento de métodos de detecção e de diagnose de fitopatógenos bacterianos, foram extensamente abordadas na revisão de Lows et al. (1999). Em Xanthomonas, já foram empregadas a análise de padrões REA de genes hrp ('hypersensitivity reaction and pathogenicity") (Leite et al., 1994; Leite et al., 1995), da região espaçadora intergênica 16S-23S e de uma região do gene groEL (Marques, 2000); a análise de padrões obtidos por rep-PCR (Bouzar et al., 1999; Lows et al., 1995) e a análise de padrões obtidos por AFLP (“Amplified Fragment Length Polymorphism”) (Rademaker et al., 2000). No caso da análise de padrões REA, genes $h r p$ foram amplificados através de iniciadores oligonucleotídicos específicos e os patovares diferenciados entre si após a restrição enzimática (Leite et al., 1994). Procedimento semelhante com a região $16 \mathrm{~S}-23 \mathrm{~S}$ e gene groEL permitiu a diferenciação entre $X$. axonopodis pv. vesicatoria e $X$. vesicatoria (Marques, 2000). Bouzar et al. (1999), por sua vez, analisaram a estrutura populacional de isolados de Xanthomonas spp. associadas à mancha-bacteriana no Caribe e na América Central através da repPCR. Foi evidenciado a predominância de certas linhagens em determinadas regiões, 
bem como um maior fluxo migratório de isolados do Caribe em direção à América Central do que na direção oposta. Utilizando o gênero Xanthomonas como modelo, Rademaker et al. (2000) indicaram que tanto a técnica de rep-PCR como a de AFLP, são adequadas para a determinação da diversidade e da estrutura filogenética de populações bacterianas, por apresentarem alta correlação com a de reassociação cinética de DNADNA.

Jones et al. (2000) compararam a sequência de 2097 bases, compreendendo o gene 16 rRNA, a região espaçadora intergênica 16S-23S e uma pequena região do gene $23 \mathrm{~S}$ do rRNA, dos quatro grupos genéticos (“A”, “A1", "B”, “C” e "D”) de Xanthomonas spp. associadas à mancha-bacteriana. O mesmo grau de relação entre os grupos, apontado quando as técnicas de PFGE e de reassociação cinética de DNA-DNA foram empregadas, foi encontrado. 


\section{EPIDEMIAS DE 'Xanthomonas gardneri’ NO BRASIL-CENTRAL}

\section{RESUMO}

Epidemias intensas de mancha-bacteriana têm sido observadas em campos comerciais de tomate para processamento industrial no Brasil Central. Considerando-se que a doença pode ser causada por Xanthomonas axonopodis pv. vesicatoria, $X$. vesicatoria ou ' $X$. gardneri', procurou-se identificar as espécies presentes nessa região. Foram obtidos 215 isolados em dez áreas comerciais nos anos 1997, 1998 e 2000 . Os isolados foram caracterizados por eletroforese de campo pulsado após digestão do DNA genômico com a enzima $X b a \mathrm{I}$, atividades amidolítica e pectolítica, presença/ausência do gene avrRxv, patogenicidade em tomate e pimentão, utilização de fontes de carbono e eletroforese de proteínas totais em gel de SDS-poliacrilamida. Para os três últimos testes foram utilizados isolados representativos de cada haplótipo e campo. Em seis campos, todos os isolados foram classificados como 'Xanthomonas gardneri', enquanto que nos outros quatro, além de ' $X$. gardneri', também foram detectadas $X$. vesicatoria e $X$. axonopodis pv. vesicatoria. Isolados de 'Xanthomonas gardneri' não foram capazes de hidrolisar amido e pectato e de utilizar gentiobiose ou maltose, mas expressaram a proteína de $27 \mathrm{kDa}$. Além disso, foram patogênicos em tomate, variáveis quanto à patogenicidade em pimentão e não apresentaram o gene $a v r R x v$. Este é o primeiro relato de epidemias causadas por 'X. gardneri' em campos de tomate no Brasil. 


\section{Epidemics of bacterial spot caused by 'Xanthomonas gardneri' in Central Brazil}

\section{SUMMARY}

Intense epidemics of bacterial spot have been observed in Central-West Brazil in fields of processing tomatoes. Since several xanthomonads, Xanthomonas axonopodis pv. vesicatoria, $X$. vesicatoria or ' $X$. gardneri', can cause the disease, attempts were made to identify the species present in this region. A total of 215 strains were obtained from ten commercial areas in 1997, 1998, and 2000. The strains were characterized using pulsed-fields gel electrophoresis (PFGE) by amylolytic and pectolytic activities, and by the presence or absence of the avrRxv gene. Representative strains from each PFGE haplotype and from each field were then tested for pathogenicity on tomato and pepper, carbon source utilization and whole protein SDS-polyacrylamide gel electrophoresis. All strains recovered from six fields were classified as 'Xanthomonas gardneri', whereas $X$. vesicatoria and $X$. axonopodis pv. vesicatoria were also detected in the remaining four fields. 'Xanthomonas gardneri' strains were unable to hydrolyze starch and pectate and to utilize gentiobiose and maltose. They expressed the $\beta$ protein of $27 \mathrm{kDa}$ and did not contain the $a v r R x v$ gene. In addition to this, all strains were pathogenic on tomato but variable on pepper. This is the first report of epidemics of bacterial spot on tomato caused by 'X. gardneri' in worldwide.

\subsection{INTRODUÇÃo}

No Brasil, as áreas de cultivo de tomate para processamento industrial, ou rasteiro (Lycopersicon esculentum Mill), estão gradualmente se deslocando das regiões sudeste e nordeste para a região Central, compreendendo principalmente os estados de Goiás e Minas Gerais (Barbosa, 1997; Silva \& Giordano, 2000). Nessa nova fronteira agrícola, a área com a cultura aumentou de 5.000 ha em 1991 para 11.000 ha em 1998, representanto a metade da área cultivada com tomate rasteiro no país. As condições edafoclimáticas na região são ideais para o cultivo extensivo irrigado e para a 
mecanização, o que resulta em produtividades médias superiores à média nacional (63 t/ha contra 46 t/ha em 1999) (Silva \& Giordano, 2000).

A mancha-bacteriana, uma importante doença do tomateiro e do pimentão (Capsicum annuum L.), tornou-se um problema comum no Brasil em campos de tomate para processamento irrigados por aspersão tradicional ou por pivô-central. A doença possui grande potencial para causar perdas severas na produção devido à baixa eficiência do controle químico, transmissão da bactéria por sementes e ausência de cultivares resistentes (Gitaitis et al., 1992; Goode \& Sasser, 1980; Jones, 1997). Três espécies de Xanthomonas estão associadas à mancha-bacteriana do tomateiro e do pimentão: Xanthomonas axonopodis pv. vesicatoria, $X$. vesicatoria e ' $X$. gardneri' (Jones et al., 2000; Jones et al., 1998a; Vauterin et al., 1995). 'X. gardneri' foi primeiramente descrita na Iugoslávia e inicialmente classificada como Pseudomonas gardneri (Šutic, 1957) e depois considerada sinônimo de X. vesicatoria (Dye, 1966). No entanto, apesar de ser geneticamente e fenotipicamente distinta de $X$. axonopodis pv. vesicatoria e de X. vesicatoria (Hidelbrand et al., 1990; Jones et al., 2000; Jones et al., 1998a), sua posição taxonômica permanece indefinida (Jones et al., 2000; Young et al., 1996).

Os critérios utilizados para caracterizar fenotipicamente essas três espécies incluem atividades amidolíticas e pectolíticas, padrões de utilização de fontes de carbono, serologia, padrões de produção de ácidos graxos, perfis eletroforéticos de proteínas totais em gel de poliacrilamida-sulfato de sódio dodecil (SDS-PAGE) e características de patogenicidade (Bouzar et al., 1994a; Jones et al., 2000; Stall et al., 1994). Além disso, características genômicas também são utilizadas, tais como análises de perfis de restrição de genes $h r p$, de eletroforese de campo pulsado (PFGE) do DNA genômico digerido por enzimas de restrição, de cinética de reassociação DNA-DNA, reação em cadeia da polimerase com iniciadores repetitivos (rep-PCR) e da homologia de seqüência do RNA ribossômico (Bouzar et al., 1999; Jones et al., 2000; Leite et al., 1994; Louws et al., 1995).

'Xanthomonas gardneri' pertence ao grupo "D” das xantomonas que causam mancha-bacteriana em tomate. A bactéria é caracterizada pela sua inabilidade em 
hidrolisar amido e pectato e pela utilização de gentiobiose como única fonte de carbono. Outras características dessa espécie são a reação com o anticorpo monoclonal 8 e a presença de uma banda típica de $27 \mathrm{kDa}$ em SDS-PAGE. Além do isolado-tipo, originalmente descrito na Iugoslávia em 1957, outros isolados de 'X. gardneri' foram recentemente identificados na Costa Rica (Bouzar et al., 1999).

Este trabalho relata a identificação e a caracterização de isolados de ' $X$. gardneri' associados a epidemias severas de mancha-bacteriana em campos comerciais de tomate para processamento industrial no Brasil-Central.

\subsection{MATERIAL E MÉTODOS}

\subsubsection{Obtenção dos isolados}

Folhas e frutos com sintomas foram coletados em campos irrigados por aspersão, com cerca de 50 a $100 \%$ de plantas doentes, nos estados de Goiás e Minas Gerais (Tabela 1). Foi coletada uma amostra por planta, sendo as plantas selecionadas arbitrariamente, percorrendo-se o campo transversalmente.

As amostras foram acondicionadas em sacos de plástico e levadas ao laboratório de Fitopatologia da Embrapa Hortaliças, em Brasília, para isolamento. Para tanto, o material vegetal foi lavado em água corrente, sendo retirados pedaços de tecido contendo lesões típicas. Esses pedaços foram então desinfestados superficialmente com etanol $70 \%$ por 10 segundos, hipoclorito de sódio $3 \%$ por 30 segundos e enxagüados em água destilada estéril. Em seguida, procedeu-se a maceração desses tecidos em 100 $\mu 1$ de água destilada estéril com um pistilo em almofariz estéril. A suspensão obtida foi riscada com auxílio de uma alça de platina em placas de Petri contendo meio de cultura Ágar-Nutriente (AN) (10 g de peptona; $3 \mathrm{~g}$ de extrato de carne; $20 \mathrm{~g}$ de ágar e $1 \mathrm{~L}$ de água). As placas foram incubadas no escuro em câmaras com temperatura controlada a $28{ }^{\circ} \mathrm{C}$ por 3 a 5 dias. Colônias amarelas isoladas foram selecionadas e transferidas para outras placas contendo meio AN para garantir a pureza do isolado. Os isolados foram armazenados em tampão fosfato $\mathrm{pH}$ 7,0 em temperatura ambiente e em meio de cultura 
Caldo-Nutriente (CN) (Sigma Chemical Co., St. Louis, MO, EUA) suplementado com $30 \%$ de glicerol a $-80^{\circ} \mathrm{C}$, para armazenamento de longa duração (Moore et al., 2001). Os isolados 75-3, XV56 (Bouzar et al., 1994b) e XG101 (Šutic, 1957) foram incluídos no estudo como representantes, respectivamente, das espécies $X$. axonopodis pv. vesicatoria, $X$. vesicatoria e 'X. gardneri'. Esses isolados foram obtidos da coleção de trabalho do Instituto Agronômico do Paraná (IAPAR), Londrina.

Tabela 1. Local, ano e número de isolados coletados em campos comerciais de tomate para processamento industrial no Brasil-Central.

\begin{tabular}{|c|c|c|c|c|}
\hline $\begin{array}{l}\text { Estado e } \\
\text { município }\end{array}$ & Ano da coleta & Campo & Variedade & $\begin{array}{l}\text { Número de } \\
\text { isolados }\end{array}$ \\
\hline \multicolumn{5}{|l|}{ Goiás } \\
\hline Itapaci & 1997 & $\begin{array}{l}1 \\
2 \\
3\end{array}$ & $\begin{array}{l}\text { 401-8 } \\
\text { Andino } \\
\text { Topmec }\end{array}$ & $\begin{array}{c}9 \\
10 \\
4\end{array}$ \\
\hline Rio Verde & 1997 & 1 & $\begin{array}{l}\text { Mistura de híbridos } \\
\text { das séries APTX e } \\
\text { Heinz, Agroceres } \\
7022 \text { e Andino }\end{array}$ & 44 \\
\hline Morrinhos & 1998 & $\begin{array}{l}2 \\
1\end{array}$ & $\begin{array}{c}\text { Santa Adelia } \\
\text { Hypeel } 108 \\
\text { Hypeel } 45\end{array}$ & $\begin{array}{c}3 \\
39\end{array}$ \\
\hline & & $\begin{array}{l}2 \\
2\end{array}$ & $\begin{array}{c}\text { Hypeel } 45 \text { (mudas) } \\
\text { Hypeel 45, Rio } \\
\text { Grande }\end{array}$ & $\begin{array}{c}6 \\
20\end{array}$ \\
\hline Morrinhos & 2000 & $\begin{array}{l}3 \\
1\end{array}$ & \begin{tabular}{c}
\multicolumn{2}{c}{ Petomec } \\
RPT 1570, Hypeel \\
108, Petoseed 6914
\end{tabular} & $\begin{array}{c}4 \\
65\end{array}$ \\
\hline \multicolumn{5}{|l|}{ Minas Gerais } \\
\hline Patos de Minas & 1998 & 1 & $\begin{array}{l}\text { Viradoro, Ragu } \\
\text { 9414, Heinz } 9498\end{array}$ & 11 \\
\hline
\end{tabular}




\subsubsection{Perfis de macrorestrição do DNA genômico em eletroforese em campo pulsado (PFGE)}

A análise dos perfis gerados por PFGE foi feita de acordo com o descrito por Egel et al. (1991), com pequenas modificações. Células bacterianas armazenadas em tampão fosfato $\mathrm{pH} \mathrm{7,0} \mathrm{foram} \mathrm{recuperadas} \mathrm{em} \mathrm{meio} \mathrm{AN} \mathrm{após} \mathrm{incubação} \mathrm{no} \mathrm{escuro} \mathrm{em}$ câmaras com temperatura controlada a $28^{\circ} \mathrm{C}$ por 5 dias. Uma massa bacteriana foi então transferida com o auxílio de uma alça de platina para tubos de plástico de fundo cônico com capacidade de $15 \mathrm{~mL}$ contendo $5 \mathrm{~mL}$ de meio $\mathrm{CN}$, em replicata e homogeneizada em agitador de tubos. O meio foi colocado em incubadora refrigerada MA 830 com agitador orbital (Marconi, Piracicaba, SP) a 148 rotações por minuto a $28{ }^{\circ} \mathrm{C}$ por cerca de 16 horas. Após esse período, as concentrações das culturas foram ajustadas para $5 \times$ $10^{8} \mathrm{UFC} / \mathrm{mL}\left(\mathrm{A}_{600}=0,3\right)$ segundo leitura em espectrofotômetro Ultrospec $\AA 3100$ pro (Amersham Pharmacia Biotech, Uppsala, Sweden), utilizando-se o meio não-inoculado para zerar o equipamento. Células sedimentadas a partir de $2 \mathrm{~mL}$ da suspensão (duas vezes $1,0 \mathrm{~mL}$ no mesmo microtubo) foram então colhidas pela centrifugação a $13.800 \times$ $g$ por 5 minutos em microcentrífuga 5415C, rotor F-45-18-11 (Eppendorf, Westbury, NY, EUA), e lavadas em $1 \mathrm{~mL}$ de tampão $\mathrm{SE}(\mathrm{NaCl} 75 \mathrm{mM}$ e EDTA $25 \mathrm{mM}$ pH 8,0). Após nova centrifugação, o sedimentado lavado foi suspendido em $500 \mu \mathrm{l}$ do mesmo tampão. A suspensão foi então diluída em igual volume de $2 \%$ (peso/volume) de agarose de baixo ponto de fusão (LMP) (Gibco BRL Life Technologies, atualmente Invitrogen Life Technologies, Carlsbad, CA, EUA), previamente preparada em tampão TE (10 mM de Tris-HCl e $1 \mathrm{mM}$ de EDTA pH 8,0), dissolvida em forno de micro-ondas e resfriada até a temperatura de cerca de $50{ }^{\circ} \mathrm{C}$. A suspensão resultante foi vertida em moldes de acrílico e deixada solidificar a $4{ }^{\circ} \mathrm{C}$ por pelo menos 20 minutos. Após a solidificação, os blocos resultantes foram colocados em solução de lise $(250 \mathrm{mM}$ de EDTA pH 9,5, 25\% de "N-lauroylsarcosine" e $1 \mathrm{mg} / \mathrm{mL}$ de proteinase $\mathrm{K}$ [ambos da Sigma Chemical]) por 15 horas a $50{ }^{\circ} \mathrm{C}$. Os blocos foram lavados em tampão TE por duas vezes por 15 minutos e 6 horas, respectivamente, e então armazenados em $250 \mathrm{mM}$ de EDTA pH 8,0 a $4{ }^{\circ} \mathrm{C}$. Após um período superior a 15 dias os blocos contendo DNA genômico foram cortados em pedaços de 2-3 $\mathrm{mm}$ e incubados quatro vezes por 45 
minutos em tampão TE. Nova incubação foi feita em $200 \mu l$ do tampão React 2 (Invitrogen Life Technologies) da enzima de restrição na concentração 1X, por 15 minutos. O tampão foi trocado e as digestões feitas em um volume final de $200 \mu$ na presença de $30 \mathrm{U}$ da enzima endonuclease de restrição XbaI (Invitrogen Life Technologies). A resolução dos fragmentos para a obtenção dos perfis foi feita em um aparato CHEF-DF II (Bio-Rad Laboratories, Hercules, CA, EUA) em géis de agarose $1,2 \%$ preparados com $0,5 \mathrm{X}$ do tampão de corrida TBE (45 mM de Tris- $\mathrm{HCl}, 45 \mathrm{mM}$ de ácido bórico e $1 \mathrm{mM}$ de EDTA pH 8,0). As corridas foram feitas a $10{ }^{\circ} \mathrm{C}$ e $6 \mathrm{~V} / \mathrm{cm}$ de gel com pulsos de 4 segundos por 1 hora seguidos por 15 segundos por 23 horas. Os géis foram corados com brometo de etídio $(0,5 \mu \mathrm{g} / \mathrm{mL})$ e fotodocumentados com aparelho Fotodyne MP-ST Polaroid (Cambridge, Reino Unido).

Os perfis obtidos foram comparados entre si e com aqueles dos isolados 75-3, XV56 e XG101, pertencentes, respectivamente, aos grupos PFGE A, B e D (sensu Jones et al., 2000). Cada perfil único foi designado como um haplótipo. Comparando-se todos os isolados aos pares, calculou-se coeficientes de similaridades $S$, a partir da conversão dos dados de restrição em dados binários (1 para presença e 0 para ausência do fragmento) de acordo com Nei \& Li, 1979:

$$
S=2 n_{\mathrm{xy}} /\left(n_{\mathrm{x}}+n_{\mathrm{y}}\right) \text { onde, }
$$

$n_{\mathrm{xy}}$ representa o número de fragmentos maiores que $100 \mathrm{~kb}$ (Egel et al., 1991) comigrantes entre dois isolados $\left(x\right.$ e $y$ ) e $n_{\mathrm{x}}$ e $n_{\mathrm{y}}$ o número total de fragmentos maiores do que $100 \mathrm{~kb}$ para $x$ e para $y$, respectivamente. O pacote computacional NTSYS-pc (versão 1,70; Exeter Software, Setaukaat, NY, EUA) ) foi utilizado para o cálculo da similaridade. Os dados obtidos foram submetidos à análise de agrupamento através do programa SAHN do mesmo pacote, empregando-se o método aritmético não ponderado de determinação de grupos (UPGMA), construindo-se também um dendrograma. 


\subsubsection{Amplificação do fragmento relacionado ao gene $a v r R x v$}

A presença do gene $a v r R x v$ foi verificada pela reação em cadeia da polimerase (PCR) em todos os isolados. DNA genômico total foi isolado pelo método de purificação CTAB (brometo de amônio-hexadeciltrimetil) como descrito em Wilson (1999), com pequenas modificações. Para a obtenção das culturas bacterianas e de seu sedimentado, procedeu-se como descrito no item 3.2.2. Após o descarte do meio líquido, o sedimentado foi posto em suspensão em $1 \mathrm{~mL}$ de água destilada estéril para lavagem, submetido à nova centrifugação e posto novamente em suspensão em $567 \mu \mathrm{L}$ de tampão TE, pH 8,0. Adicionou-se $10 \%$ de SDS e $3 \mu \mathrm{L}$ de proteinase $\mathrm{K}(20 \mathrm{mg} / \mathrm{mL})$, seguindose à cada adição uma agitação vigorosa em agitador de tubos MA 162 (Marconi, Piracicaba, SP). Os microtubos foram então incubados a $37{ }^{\circ} \mathrm{C}$ por 1,5 hora em banhomaria ou estufa. Após esse período, adicionou-se $100 \mu \mathrm{L}$ de $5 \mathrm{M}$ de $\mathrm{NaCl}$ e agitou-se novamente. Em seguida, foi adicionado $\mathrm{CTAB} / \mathrm{NaCl}(4,1 \mathrm{~g} \mathrm{NaCl}$ e $10 \mathrm{~g}$ de CTAB em $100 \mathrm{~mL}$ de água) e a suspensão resultante incubada por 10 minutos a $65{ }^{\circ} \mathrm{C}$ em banhomaria. Adicionou-se então $780 \mu \mathrm{L}$ de clorofórmio-álcool iso-amílico (24:1), agitou-se manualmente por 10 minutos e centrifugou-se em seguida por mais 5 minutos. $\mathrm{O}$ sobrenadante foi removido para novos tubos de microcentrífuga onde adicionou-se fenol-clorofórmio-álcool iso-amílico (25:24:1), procedendo-se como no passo anterior. $\mathrm{O}$ sobrenadante foi novamente transferido para novos tubos onde adicionou-se $600 \mu \mathrm{L}$ de isopropanol para promover a precipitação do DNA por agitação manual suave dos tubos. Após a precipitação do DNA, as amostras foram incubadas por 10 minutos a $-70^{\circ} \mathrm{C}$ e em seguida centrifugadas por 20 a 25 minutos a $13.800 \times g$. Após o descarte do sobrenadante, efetuou-se uma lavagem do DNA em $70 \%$ de etanol com centrifugação por 10 minutos. Após o descarte do etanol, o precipitado foi seco em estufa a $37{ }^{\circ} \mathrm{C}$ por 10 a 15 minutos e a temperatura ambiente por aproximadamente 12 horas. O DNA foi então suspendido em $50 \mu \mathrm{L}$ de tampão TE pH 8,0 com RNAse $(10 \mu \mathrm{L} / \mathrm{mL})$ e, após 1 hora, armazenado a $4{ }^{\circ} \mathrm{C}$ até o uso. A reação da PCR, em um volume final de $50 \mu \mathrm{L}$, foi composta por $100 \mathrm{ng}$ do DNA molde, $5 \mu \mathrm{L}$ de tampão de amplificação (Promega Life Science, Madison, WI, EUA), 1,5 mM de $\mathrm{MgCl}_{2}, 1,25 \mathrm{U}$ de Taq DNA polimerase 
(Promega), $100 \mu \mathrm{M}$ de cada deoxinucleosídeo trifosfato (dNTPs) e 0,5 $\mu \mathrm{M}$ dos iniciadores RST27 (5'-AGTCGCGCGGACATTTAGCCCCGCC) and RST28 (5'CGTCGATGGTGCGCCTGGAATGCGC) (Bouzar et al., 1994a). O programa de amplificação constou de 30 ciclos, realizados em um termociclador PTC-100 MJ Research Inc. (Watertown, MA, EUA), nas seguintes condições: desnaturação a $95{ }^{\circ} \mathrm{C}$ por 30 segundos, hibridização a $64{ }^{\circ} \mathrm{C}$ por 30 segundos e extensão a $72{ }^{\circ} \mathrm{C}$ por 45 segundos. $\mathrm{O}$ último passo de extensão a $72^{\circ} \mathrm{C}$ foi de 5 minutos. Os produtos da PCR foram detectados por eletroforese em gel de $1 \%$ de agarose em tampão de corrida TBE $0,5 \mathrm{X}$ a $5 \mathrm{~V} / \mathrm{cm}$ de gel. Os géis foram corados com brometo de etídio $(0,5 \mu \mathrm{g} / \mathrm{mL})$ e fotodocumentados com aparelho Image Master ${ }^{\circledR}$ VDS (Pharmacia Biotech, San Francisco, EUA).

\subsubsection{Hidrólise de amido e de pectato}

Todos os isolados foram testados quanto à habilidade em hidrolisar amido e pectado. Para tanto, uma massa bacteriana da cultura previamente recuperada em meio AN foi transferida, com o auxílio de uma alça de platina de cerca de $3 \mathrm{~mm}$ de diâmetro, para $10 \mathrm{~mL}$ de água destilada estéril e homogeneizada em agitador de tubos. Alíquotas de $10 \mu \mathrm{L}$ das suspensões bacterianas resultantes foram depositadas, respectivamente, em meio AN suplementado com $1 \%$ de amido de milho (Maizena ${ }^{\circledR}$ ) ou em meio cristal de violeta-pectato (CVP) sem o cristal de violeta (Cuppels \& Kelman, 1974). Inferiu-se que houve atividade amidolítica quando as colônias bacterianas apresentaram um halo transparente após o encharcamento das placas com iodeto de lugol. No caso da atividade pectolítica, observou-se a formação de uma depressão no meio no local do depósito da suspensão. Em ambos os testes, o isolado XV56 foi usado como controle positivo e os isolados 75-3 e XG101 como controles negativos.

\subsubsection{Testes de patogenicidade}

Noventa e quatro isolados representando os haplótipos dos grupos definidos pela PFGE em cada evento de coleta foram inoculados nas cultivares suscetíveis Walter 
(tomate) e Early Calwonder (pimentão) (Bouzar et al., 1994b). Para a obtenção das plantas, fez-se o semeio de duas sementes por célula em bandejas de poliestereno de 128 células preenchidas com substrato agrícola Plantmax ${ }^{\circledR}$ (Eucatex). As plantas foram transplantadas (uma planta/saco) com duas a três folhas verdadeiras ( 2 e 3 semanas para as plantas de tomate e de pimentão, respectivamente) para sacos de plástico pretos com capacidade de 1,0 L, preenchidos com solo esterelizado. Para a obtenção das culturas bacterianas, procedeu-se como descrito no item 3.2.2, utilizando-se $15 \mathrm{~mL}$ de meio $\mathrm{CN}$ em tubo de plástico com fundo cônico com capacidade de $50 \mathrm{~mL}$ em duas replicatas por isolado. As suspensões obtidas foram então centrifugadas em centrífuga Beckman GS-6 (Palo Alto, CA, EUA), rotor GH3.8, a $2.800 \times g$ por 20 minutos e o sedimentado resultante posto em suspensão em água destilada, ajustando-se a concentração para $5 \times$ $10^{8} \mathrm{UFC} / \mathrm{mL}$ em espectrofotômetro $\left(\mathrm{A}_{600}=0,3\right)$. Posteriormente, a suspensão foi diluída em 1:10 para a inoculação das plantas, utilizando-se um pulverizador portátil manual. As plantas foram inoculadas no estádio de quatro a cinco folhas verdadeiras (6 e 5 semanas após o semeio para plantas de pimentão e de tomate, respectivamente) e mantidas em câmaras úmidas individuais, feitas com sacos de plástico transparentes, por 2 dias. Após esse período, as plantas permaneceram em casa-de-vegetação $\left(25\right.$ a $\left.35{ }^{\circ} \mathrm{C}\right)$. Foram inoculadas duas plantas de cada cultivar com cada isolado. O desenvolvimento dos sintomas foi observado periodicamente por até 21 dias após a inoculação.

\subsubsection{Utilização de fonte de carbono}

Foram testados os açúcares gentiobiose (Acros Organics, New Jersey, EUA), maltose (Carlo Erba, Milão, Itália), $\mathrm{D}(+)$ melezitose (Acros Organics), $\mathrm{D}(+)$ rafinose (Acros Organics) e $\mathrm{D}(+)$ trealose (Sigma) (Bouzar et al., 1999; Dye, 1966). Para tanto, alíquotas de $10 \mu \mathrm{L}$ da suspensão bacteriana, preparadas em água destilada estéril como descrito no item 3.2.4, foram depositadas sobre placas com meio $\mathrm{C}$ de Dye $(0,5 \mathrm{~g}$ de $\mathrm{NH}_{4} \mathrm{H}_{2} \mathrm{PO}_{4} ; 0,5 \mathrm{~g}$ de $\mathrm{K}_{2} \mathrm{HPO}_{4} ; 0,2 \mathrm{~g}$ de $\mathrm{MgSO}_{4} .7 \mathrm{H}_{2} \mathrm{O} ; 5 \mathrm{~g}$ de $\mathrm{NaCl} ; 1 \mathrm{~g}$ de extrato de levedura; 12 g de ágar e 1 L de água destilada; $\mathrm{pH}$ 6,8) suplementado com 0,5\% de uma das fontes de carbono (Jones \& Geider, 2001). Para tanto, soluções-estoque foram

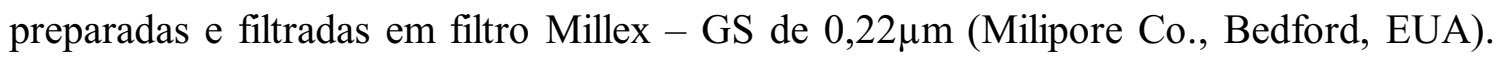


As placas inoculadas foram mantidas em câmaras de crescimento com temperatura controlada a $28{ }^{\circ} \mathrm{C}$ no escuro por até 5 dias. $\mathrm{O}$ crescimento bacteriano durante esse período foi comparado ao ocorrido em placas com o mesmo meio sem a adição de fonte de carbono. Foram utilizadas duas placas por isolado. O teste foi realizado com 21 isolados incluindo os haplótipos previamente definidos por PFGE e os isolados 75-3, XV56 e XG101.

\subsubsection{Eletroforese de proteínas solúveis}

Vinte e um isolados e os isolados 75-3, XV56 e XG101 foram caracterizados quanto aos seus perfis de proteínas pela separação eletroforética em uma dimensão (Bouzar et al., 1994A; Stall et al., 1994). Extratos totais de proteínas das células foram otidos a partir de $2 \mathrm{~mL}$ de suspensão bacteriana obtida como descrito no item 3.2.2. O sedimentado foi posto em suspensão em $200 \mu 1$ de tampão de lise $(51,4 \mathrm{mM}$ de Tris-HCl pH 6,8; 1,67 \% de SDS; $10 \%$ de 2-mercaptoetanol; $16,7 \%$ de glicerol e $0,01 \%$ de azul de bromofenol) e a suspensão resultante aquecida a $100^{\circ} \mathrm{C}$ por 10 minutos e centrifugada em centrífuga Jouan B4i (Saint Herblain, França), rotor AB 1.14, a $16,000 \times g$ por 10 minutos. Alíquotas de 12,5 $\mu \mathrm{l}$ foram depositadas em gel descontínuo consistindo de um gel de concentração ( $5 \%$ de acrilamida total; $62 \mathrm{mM}$ de Tris- $\mathrm{HCl} \mathrm{pH} 8,9$ e $0,05 \%$ de SDS) e um gel de separação (10\% de acrilamida total; $378 \mathrm{mM}$ de Tris- $\mathrm{HCl} \mathrm{pH}$ 6,8 e $0,05 \%$ de SDS). O ar foi retirado das soluções por 15 minutos com auxílio de uma bomba de vácuo e as mesmas foram polimerizadas pela adição de $0,03 \%$ de persulfato de amônio e $0,001 \%$ de tetrametiletilediamina (Temed). A eletroforese foi conduzida a 4 ${ }^{\circ} \mathrm{C}$ em um aparato de eletroforese duplo vertical Protean II (Bio-Rad Laboratories) preenchido com tampão de corrida (52 $\mathrm{mM}$ de Tris; $53 \mathrm{mM}$ de glicina $\mathrm{pH} 8,9$ e $0,1 \%$ de SDS). A voltagem foi de $100 \mathrm{~V}$ até que as amostras atingissem o gel de separação, quando então foi aumentada para $180 \mathrm{~V}$, permanecendo assim até o final da corrida. Para a coloração do gel, o mesmo foi inicialmente transferido para $250 \mathrm{~mL}$ de solução fixadora ( $40 \%$ de etanol e $10 \%$ de ácido acético) por 15 horas, em seguida para $250 \mathrm{~mL}$ de solução incubadora (17 g de acetato de sódio tri-hidratado; $75 \mathrm{~mL}$ de etanol; $1 \mathrm{~g}$ de 
tiossulfato de sódio; $1,3 \mathrm{~mL}$ de glutaraldeído $25 \%$ ) por 15 minutos e depois lavado por três vezes com água deionizada por 10 minutos cada lavagem em agitação constante e suave. Após as lavagens, o gel foi transferido para $250 \mathrm{~mL}$ de solução de prata $(0,25 \mathrm{~g}$ de nitrato de prata e $25 \mu \mathrm{L}$ de formaldeído) por 20 minutos e em seguida para $250 \mathrm{~mL}$ de solução reveladora (6,25 g de $\mathrm{NaCO}_{3}$ e $25 \mu \mathrm{L}$ de formaldeído) até o aparecimento das bandas. O gel foi então transferido para a solução de parada, em volume suficiente para cobrí-lo, $\left(3,65 \mathrm{~g}\right.$ de Na.EDTA.2. $\left.\mathrm{H}_{2} \mathrm{O}\right)$ por 10 minutos e posteriormente lavado em água corrente durante 2 horas.

\subsection{RESULTADOS}

\subsubsection{Análise de PFGE e deteç̧ão do gene avrRxv}

Foi possível distingüir seis haplótipos, representados pelos isolados CNPH345, CNPH420, CNPH467, CNPH468, CNPH485 e CNPH496, entre os 215 isolados coletados (Figura 1). Esses haplótipos, e os representados pelos isolados 75-3, XV56 e XG101, foram posteriormente agrupados em três grupos PFGE de acordo com seus coeficientes de similaridade (Tabela 2, Figura 2). O primeiro grupo foi representado pelos isolados 75-3, CNPH420, CNPH468 e CNPH485, apresentando coeficientes de similaridade variando de 86 a $93 \%$. O segundo grupo, compreendeu os isolados XV56 e CNPH345, similares entre si em apenas $46 \%$. O terceiro grupo, representado pelos isolados XG101, CNPH467 e CNPH496, apresentou coeficientes de similaridade variando de 64 a 91\%. O gene avrRxv foi detectado apenas nos isolados 75-3 e naqueles pertencentes ao grupo PFGE 1 (Figura 3). 


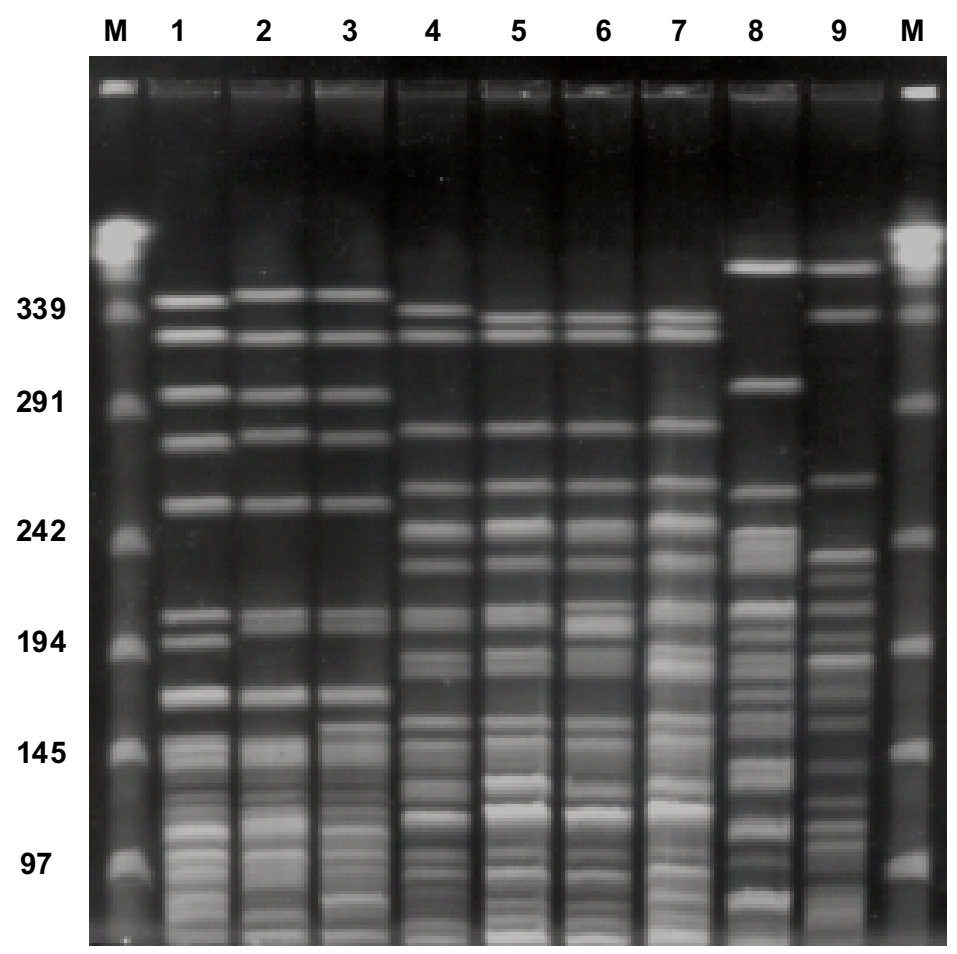

Figura 1 - Perfis de macrorestrição com a enzima XbaI de isolados de Xanthomonas spp. associadas à mancha bacteriana do tomateiro. Poço $\mathrm{M}$, marcador $\lambda$ DNAPFGE (New England Biolabs, Beverly, MA). Poço 1, XG101 (' $X$. gardneri'); poços 2 e 3, CNPH467 e CNPH496; 4, 75-3 (X. axonopodis pv. vesicatoria); 5 a 7, CNPH420, CNPH468 e CNPH485; 8, XV56 (X. vesicatoria) e 9, CNPH345. Pesos moleculares dados em kilobases. 
Tabela 2. Coeficientes de similaridade $\mathrm{a}^{\mathrm{a}}$ entre haplótipos de Xanthomonas spp. associadas à mancha-bacteriana no Brasil-Central, com base nos perfis de DNA por eletroforese de campo pulsado (PFGE).

\begin{tabular}{|c|c|c|c|c|c|c|c|c|c|}
\hline \multirow{3}{*}{ Isolados } & \multicolumn{9}{|c|}{ Grupos PFGE e isolados de Xanthomonas spp. } \\
\hline & \multicolumn{4}{|c|}{1} & \multicolumn{2}{|c|}{2} & \multicolumn{3}{|c|}{3} \\
\hline & $75-3$ & CNPH420 & CNPH468 & CNPH485 & XV56 & CNPH345 & XG101 & CNPH467 & CNPH496 \\
\hline $75-3$ & - & 92 & 86 & 86 & 44 & 40 & 25 & 33 & 33 \\
\hline CNPH420 & - & - & 93 & 93 & 44 & 32 & 25 & 33 & 33 \\
\hline CNPH468 & - & - & - & 87 & 48 & 37 & 31 & 31 & 31 \\
\hline CNPH485 & - & - & - & - & 41 & 30 & 23 & 31 & 31 \\
\hline XV56 & - & - & - & - & - & 46 & 24 & 16 & 24 \\
\hline CNPH345 & - & - & - & - & - & - & 26 & 17 & 17 \\
\hline XG101 & - & - & - & - & - & - & - & 73 & 64 \\
\hline CNPH467 & - & - & - & - & - & - & - & - & 91 \\
\hline CNPH496 & - & - & - & - & - & - & - & - & - \\
\hline
\end{tabular}

${ }^{\text {a }}$ Coeficiente de similaridade de Dice em \% (Nei \& Li, 1979)

\section{Similaridade}

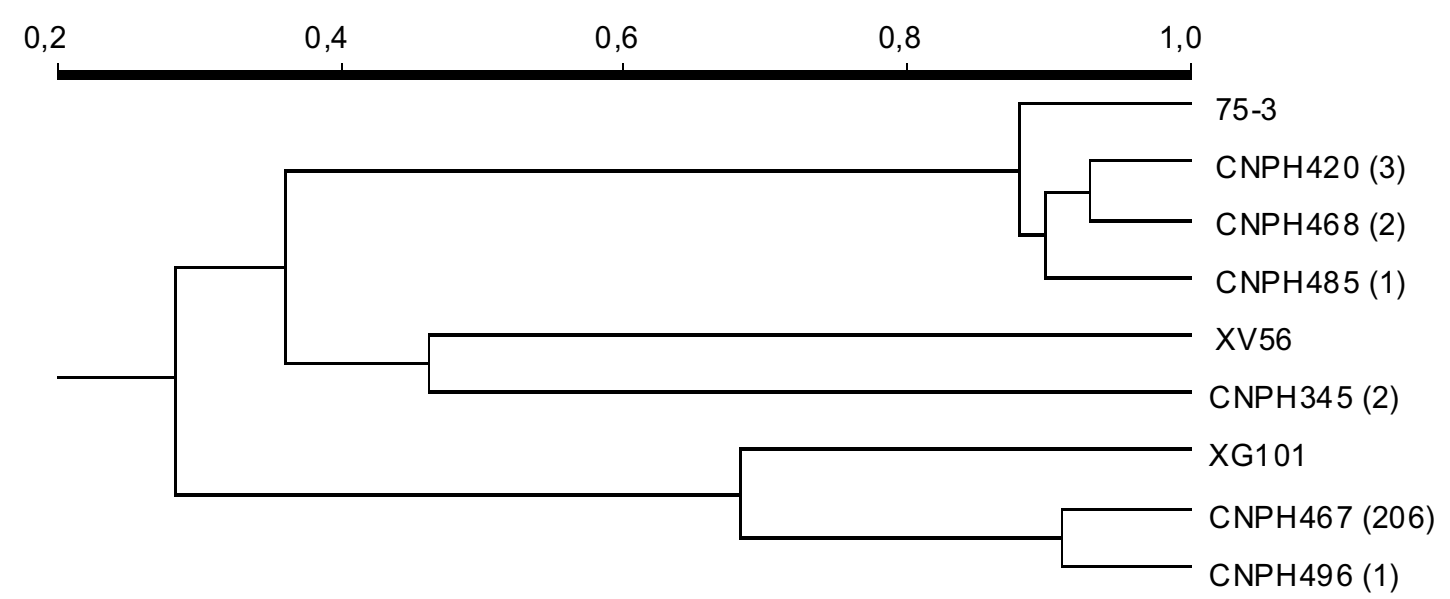

Figura 2 - Dendrograma de haplótipos de Xanthomonas spp. associadas à mancha bacteriana do tomateiro determinados pelos perfis únicos de macrorestrição com $X b a \mathrm{I}$ resolvidos por eletroforese de campo pulsado. O número de isolados apresentando o mesmo perfil aparece entre parênteses. 


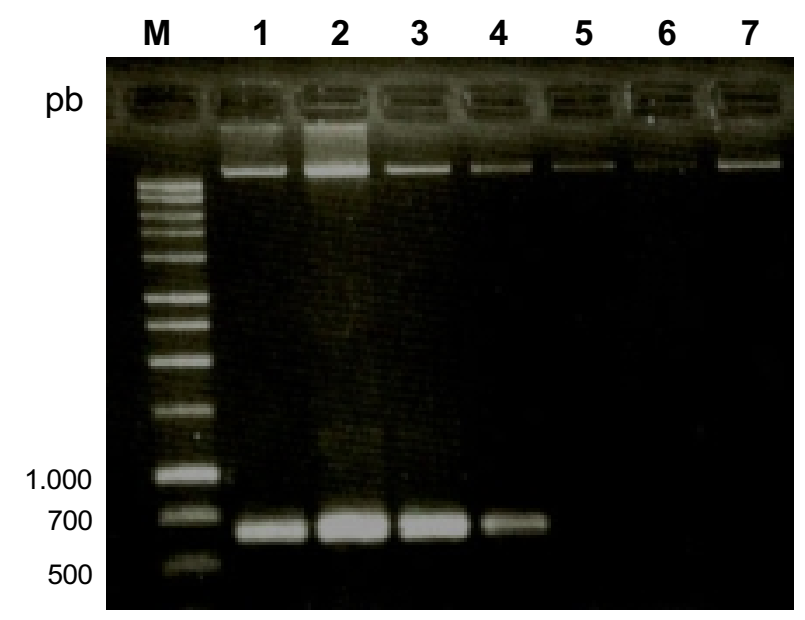

Figura 3 - Fragmentos de DNA genômico de Xanthomonas spp. associadas à mancha bacteriana do tomateiro contendo o gene avrRxv. Poço $\mathrm{M}$, marcador molecular $1 \mathrm{~kb}$ (Promega Corporation, Mandison, WI, USA); poços 2 a 5, $X$. axonopodis pv. vesicatoria isolado 75-3 e isolados CNPH420, CNPH468 e 485; poços 6 a 8, 'X. gardneri' isolado XG101 e isolados CNPH467 e CNPH496.

\subsubsection{Caracterização fenotípica}

As características fenotípicas foram, em geral, uniformes entre isolados pertencentes ao mesmo grupo. Nenhum dos isolados pertencentes ao grupo 1, por exemplo, apresentaram atividades amidolítica e pectolítica, mas todos foram patogênicos tanto às plantas de tomate quanto de pimentão (Tabela 3). Além disso, assim como o isolado 75-3, três outros isolados desse grupo foram caracterizados quanto aos perfis de proteína e quatro quanto à utilização de fonte de carbono. Esses isolados apresentaram, respectivamente, a proteína $\alpha$ (sensu Bouzar et al., 1993) de 32-kDa (Figura 4) e utilizaram gentiobiose, maltose e $\mathrm{D}(+)$ trealose. No entanto, eles diferiram entre si quanto à habilidade de usar melezitose e $\mathrm{D}(+)$ rafinose.

Já os isolados pertencentes ao grupo PFGE 2, por sua vez, foram capazes de hidrolisar amido e pectato, foram patogênicos somente ao tomateiro (Tabela 3), e 
apresentaram a proteína $\beta$ (sensu Bouzar et al., 1993) de 27-kDa. Esse grupo foi representado pelos isolados XV56 e CNPH345 nas análises de proteínas totais e utilização de fontes de carbono. A exemplo dos isolados do grupo 1, eles utilizaram gentiobiose, maltose, $\mathrm{D}(+)$ trehalose e $\mathrm{D}(+)$ rafinose. No entanto, somente o isolado CNPH345 utilizou $\mathrm{D}(+)$ melezitose.

Os isolados do grupo PFGE 3 não hidrolisaram amido e pectato, como os do grupo 1. Foram patogênicos às plantas de tomate mas nem todos às plantas de pimentão (Tabela 3). A caracterização dos perfis de proteínas e de utilização de fontes de carbono foi realizada, respectivamente com 16 e 22 isolados desse grupo. Como o isolado XG101, a presença da proteína $\beta$ foi uniforme entre eles, bem como a incapacidade de utilizar gentioiose, maltose, $\mathrm{D}(+)$ melezitose e $\mathrm{D}(+)$ trehalose. A utilização de $\mathrm{D}(+)$ rafinose, por sua vez, foi variável.

Tabela 3. Número de isolados de Xanthomonas spp. patogênicas ao tomateiro e às plantas de pimentão provenientes do Brasil-Central, de acordo com o grupo PFGE $^{\mathrm{a}}$.

\begin{tabular}{cccc}
\hline Grupos PFGE & $\begin{array}{c}\text { Número de isolados } \\
\text { testados }\end{array}$ & $\begin{array}{c}\text { Cv. Walter } \\
\text { (tomate) }\end{array}$ & $\begin{array}{c}\text { Cv. Early Calwonder } \\
\text { (pimentão) }\end{array}$ \\
\hline 1 & 6 & 6 & 6 \\
2 & 2 & 2 & 0 \\
3 & 86 & 86 & 74 \\
\hline
\end{tabular}




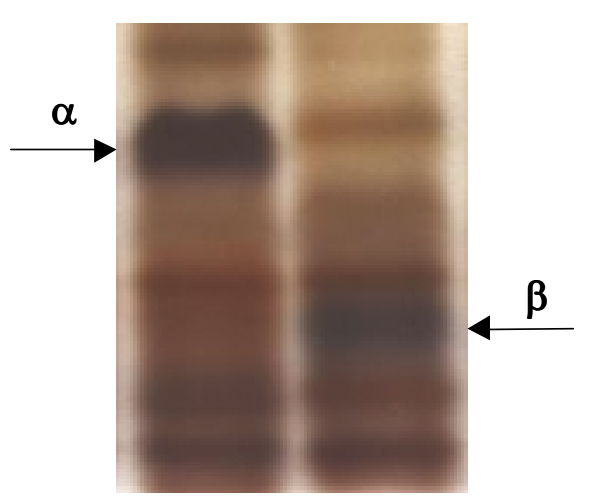

Figura 4 - Eletroferograma de proteínas desnaturadas obtidas a partir de células de Xanthomonas spp. associadas à mancha bacteriana do tomateiro lisadas com SDS. Poço 1, isolado CNPH420. Poço 2, isolado CNPH467. Setas indicam bandas de 32-kDa (esquerda) e de 27-kDa (direita), respectivamente, bandas $\alpha$ e $\beta$ sensu Bouzar et al., 1994a.

\subsubsection{Identificação das espécies e freqüência}

Com base nas características genotípicas e fenotípicas apresentadas anteriormente, os isolados dos grupos PFGE 1, PFGE 2 e PFGE 3 foram classificados, respectivamente, $X$. axonopodis pv. vesicatoria, $X$. vesicatoria e 'Xanthomonas gardneri'. 'Xanthomonas gardneri' foi a única espécie detectada em seis campos, enquanto que nos demais também foram encontrados $X$. axonopodis pv. vesicatoria e $X$. vesicatoria (Tabela 4). 
Tabela 4. Freqüência de Xanthomonas ${ }^{\mathrm{a}}$ spp. isoladas de tomateiro em campos para processamento no Brasil-Central durante os anos de 1997, 1998 e 2000.

\begin{tabular}{|c|c|c|c|c|c|c|}
\hline \multirow[t]{2}{*}{$\begin{array}{l}\text { Estado e } \\
\text { município }\end{array}$} & \multirow[t]{2}{*}{ Ano da coleta } & \multirow[t]{2}{*}{ Campo } & \multirow[t]{2}{*}{$\begin{array}{l}\text { Número de } \\
\text { isolados }\end{array}$} & \multicolumn{3}{|c|}{ Freqüência das espécies $(\%)$} \\
\hline & & & & $X G$ & XAV & $\mathrm{XV}$ \\
\hline \multicolumn{7}{|l|}{ Goiás } \\
\hline \multirow[t]{3}{*}{ Itapaci } & 1997 & 1 & 9 & 100,0 & 0,0 & 0,0 \\
\hline & & 2 & 10 & 100,0 & 0,0 & 0,0 \\
\hline & & 3 & 4 & 50,0 & 0,0 & 50,0 \\
\hline \multirow[t]{2}{*}{ Rio Verde } & 1997 & 1 & 44 & 100,0 & 0,0 & 0,0 \\
\hline & & 2 & 3 & 100,0 & 0,0 & 0,0 \\
\hline \multirow[t]{4}{*}{ Morrinhos } & 1998 & 1 & 39 & 94,9 & 5,1 & 0,0 \\
\hline & & $2^{2}$ & 6 & 66,7 & 33,3 & 0,0 \\
\hline & & 2 & 20 & 95,0 & 5,0 & 0,0 \\
\hline & & 3 & 4 & 75,0 & 25,0 & 0,0 \\
\hline Morrinhos & 2000 & 1 & 65 & 100,0 & 0,0 & 0,0 \\
\hline \multicolumn{7}{|l|}{ Minas Gerais } \\
\hline Patos de Minas & 1998 & 1 & 11 & 100,0 & 0,0 & 0,0 \\
\hline
\end{tabular}

1. $\mathrm{XG}=$ Xanthomonas gardneri, $\mathrm{XAV}=$ Xanthomonas axonopodis pv. vesicatoria, $\mathrm{XV}=$ Xanthomonas vesicatoria. Essas são as espécies a que pertencem, respectivamente, os isolados dos grupos PFGE 3, 1 e 2 deste capítulo.

2. Coleta realizada em mudas de 'Hypeel 45' no dia do transplantio.

\subsection{DISCUSSÃO}

Os perfis PFGE e características fenotípicas foram utilizados para classificar os isolados de Xanthomonas em nível de espécie. Desse modo, a maioria dos isolados pertenceram ao grupo PFGE 3 e foram classificados como 'X. gardneri'. Contribuem ainda mais para essa classificação os fatos de, como o isolado de referência XG101 (Dye, 1966), os isolados do Brasil-Central não utilizaram $\mathrm{D}(+)$ melezitose e gentiobiose, mas utilizaram $\mathrm{D}(+)$ trealose. Além disso, a não-utilização de gentiobiose está de acordo com relatos anteriores sobre isolados de 'X. gardneri' na Costa Rica (Bouzar et al., 1999). Entre as fontes de carbono utilizadas, gentiobiose e maltose foram as mais 
discriminatórias, com resultados negativos apenas para as isolados de 'X. gardneri', o que está de acordo com relatos anteriores onde a gentiobiose também foi testada (Bouzar et al., 1999). O substrato maltose, por sua vez, parece igualmente ter um valor diagnóstico. Porém, um maior número de isolados representando todos os grupos fenotípicos de $X$. axonopodis pv. vesicatoria (A, A1 and C sensu Jones et al., 2000) e X. vesicatoria deve ainda ser avaliado.

Membros de ' $X$. gardneri' ou foram patogênicos às plantas de tomate e de pimentão, ou somente às plantas de tomate. Já na Costa Rica, isolados patogênicos apenas às plantas de pimentão também foram encontrados (Bouzar et al., 1999). Ainda não se sabe se a gama de hospedeiras observadas para ' $X$. gardneri' é, como no caso de $X$. axonopodis pv. vesicatoria e $X$. vesicatoria, igualmente determinada pelos genes de avirulência avrBsT (Minsavage et al., 1990) e avrBsP (Canteros et al., 1991). Esses genes induzem, respectivamente, resposta de hipersensibilidade em todas as linhagens de pimentão e de tomate. Nas folhas do tomateiro, os sintomas causados por esses isolados apareceram na forma de manchas marrom-escuras e planas, circundadas por áreas encharcadas, semelhante aos previamente descritos para $X$. vesicatoria (Bouzar et al., 1994a). A coalescência dos sintomas resultou em um aspecto de queima. Como para $X$. vesicatoria (Jones et al., 1998a), nenhum isolado de ' $X$. gardneri' apresentou o gene de avirulência avrRxv. Esse fato inviabiliza o uso da resistência derivada da linhagem 'Hawaii 7998' em programas de melhoramento. Genes de resistência derivados dessa linhagem interagem com o gene avrRxv resultando em uma reação de hipersensibilidade (Jones et al., 1998a).

Até recentemente, ' $X$. gardneri' era tratada como uma espécie de ocorrência esporádica (Jones et al., 2000). Porém, o fato de ' $X$. gardneri' ter sido recuperada em elevada freqüência no Brasil-Central pode ser um indicativo de que essa espécie está se tornando um componente importante do complexo da mancha-bacteriana, uma vez que epidemias ainda não haviam sido relatadas no país. A ocorrência de novas espécies e tipos de xantomonas causando mancha-bacteriana em tomate rasteiro no Brasil pode ser atribuída a uma substituição gradual das variedades de polinização aberta por variedades híbridas. Enquanto as primeiras são provenientes de programas de melhoramento 
nacional ou importadas basicamente da Califórnia, os híbridos são comercializados por empresas internacionais de sementes e possuem uma origem mais diversa (Barbosa, 1997). Um fator crucial para a introdução de patógenos bacterianos do tomateiro no campo onde antes não existiam parece ser o emprego de sementes contaminadas (Bashan \& Okon, 1986; Goode \& Sasser, 1980; Leite et al., 1994). Em Morrinhos, em 1998, sintomas da doença foram observados em mudas comercialmente produzidas em telados. Esse fato é uma indicação de que sementes infectadas e/ou infestadas tenham sido utilizadas. Além disso, tratava-se do primeiro ano de cultivo de lavoura de tomate e, apesar da introdução de um calendário intensivo de aplicação de cobre, a doença tornouse abrangente. É intrigante o fato que a proporção de isolados de $X$. axonopodis pv. vesicatoria, em relação àqueles de ' $X$. gardneri', tenha caído de $33 \%$ do total de isolados recuperados das mudas doentes coletadas na ocasião do transplantio, para apenas $6,5 \%$ do total de isolados obtidos posteriormente no mesmo campo das plantas de Hypeel 45 em estádio de maturação mais avançado. Especula-se, aqui, que possam ocorrer entre essas duas espécies, diferenças em adaptabilidade ou em competitividade, como já demonstrado em relação às raças $\mathrm{T} 1$ e $\mathrm{T} 3$ de $X$ axonopodis pv. vesicatoria (Jones et al., 1998a).

Uma vez que este trabalho representa o primeiro levantamento de espécies de Xanthomonas causando mancha-bacteriana no Brasil-Central, não é possível inferir com exatidão quando ocorreu o estabelecimento de ' $X$. gardneri' nessa região. $\mathrm{O}$ entendimento do complexo causador da mancha-bacteriana no país é o primeiro passo para o direcionamento de estudos que visem a aquisição de um melhor nível de controle da doença no campo, tais como detecção, sobrevivência, eficiência do controle químico e melhoramento. 


\section{DIVERSIDADE GENÉTICA DE Xanthomonas SPP. ASSOCIADAS À MANCHA-BACTERIANA NAS MACRO-REGIÕES PRODUTORAS BRASIL- CENTRAL E NORDESTE}

\section{RESUMO}

A ocorrência dos grupos genéticos/espécies de Xanthomonas associadas à mancha-bacteriana em lavouras de tomateiro rasteiro no Brasil é pouco conhecida. Através de características fenotípicas e genotípicas foram analisados 447 isolados obtidos no período de 1995 a 2000 nas macro-regiões produtoras Brasil-Central e Nordeste. Quatro grupos de perfis de eletroforese de campo pulsado (PFGE) foram identificados, sendo que três deles (PFGE 1, 3 e 4) corresponderam, respectivamente, às espécies $X$. axonopodis pv. vesicatoria, $X$. vesicatoria e ' $X$. gardneri'. O grupo PFGE 2 foi tentativamente considerado um subgrupo da primeira espécie. O grupo PFGE 1 foi o único que ocorreu nas duas regiões, com predominância no Nordeste, enquanto o PFGE 2 só ocorreu nessa região e os grupos 3 e 4 apenas no Brasil-Central. Esse é o primeiro relato da ocorrência do grupo 2 no país. A relação da diversidade genética das populações bacterianas com a origem macro-geográfica e o tipo de variedade da qual foram coletadas (híbridas importadas ou de polinização aberta nacional [PA]) foi verificada, em análises independentes, através de índices de diversidade de Nei e da análise de variância molecular (AMOVA). A diversidade intra-populacional foi baixa nas duas macro-regiões e tipos de variedade, representando a menor proporção da diversidade genética total e indicando que as populações foram em geral clonais. Não obstante, menor diversidade intra-populacional foi verificada em variedades híbridas do que em PA nacionais. Da mesma forma, populações do Brasil-Central foram menos 
variáveis que as do Nordeste. Esses fatos se explicam pela predominância em variedades PA nacionais e macro-região Nordeste de isolados pertencentes ao grupo PFGE 1, que apresentou-se mais polimórfico, em oposição aos grupos 3 e 4, menos variáveis, que predominaram em variedades híbridas e no Brasil-Central. A maior proporção da variação genética foi atribuída ao componente inter-populacional tanto na análise da macro-região como do tipo de variedade. No entanto, variação considerável existiu entre as macro-regiões e entre os tipos de variedade.

\section{Genetic diversity of Xanthomonas spp. associated with bacterial spot on tomato for processing fields in Central Brazil and Northeast}

\section{SUMMARY}

The occurrence of genetic groups/species of Xanthomonas associated with bacterial spot in tomatoes for processing crops in Brazil is unknown. Four hundred and fourty-seven strains isolated from commercial areas in Central Brazil and Northeast during 1995 to 2000 were phenotipically and genotypically characterized. Four pulsedfield electrophoresis (PFGE) fingerprint groups were identified. Three of them (PFGE 1, 3 and 4) corresponded, respectively, to $X$. axonopodis pv. vesicatoria, X. vesicatoria and ' $X$. gardneri'. PFGE group 2 was tentatively classified as a subgroup of the first species. PFGE group 1 was the only one present in both regions, predominating in the Northeast. PFGE 2 occurred only in this region and groups 3 and 4 only in Central Brazil. This is the first report of occurrence of PFGE group 2 in Brazil. Nei's diversity indexes and analysis of molecular variance (AMOVA) were used to verify the relationship between the genetic diversity of populations with their macrogeographical origin and types of varieties from which they were collected (imported hybrids and national open polinated varieties $[\mathrm{OP}]$ ), in two independent analysis. The intra-populational diversity was low in both regions and types of varieties and represented the lowest proportion of total genetic diversity, indicating that the populations were in general clonal. However, intra- 
populational diversity was lower among hybrids than among national OP varieties. Similarly, populations from Central-Brazil were less variable than the ones from Northeast. These facts are explained by the predominance of strains from the more variable PFGE group 1 in OP varieties and in the Northeast region as opposed to the less variable groups 3 and 4 which predominated in hybrids and in Central Brazil. The greatest proportion of genetic variation was attributed to the inter-populational component in both analyses. However, considerable variation existed among macrogeographic regions or types of variety.

\subsection{INTRODUÇÃO}

As três principais regiões de cultivo de tomate para processamento industrial (Lycopersicon esculentum Mill.) no Brasil estão localizadas no estado de São Paulo (4.550 ha em 1998), Pernambuco e Bahia (6.600 ha) e Minas Gerais e Goiás (11.130 ha), esta última considerada a nova fronteira da cultura (Barbosa, 1997; Silva \& Giordano, 2000). A produção brasileira, que se iniciou em Pernambuco no início do século XX, foi de 1,3 milhão de toneladas colhidas em mais de 20 mil hectares no ano de 1999 (Silva \& Giordano, 2000).

Uma das doenças mais importantes do tomateiro rasteiro no país é a manchabacteriana, que ocorre freqüentemente em áreas irrigadas por aspersão ou em períodos chuvosos. A etiologia da mancha-bacteriana, doença conhecida por muito tempo como causada pela bactéria Xanthomonas campestris pv. vesicatoria, tem sido estudada através de várias abordagens fenotípicas e genotípicas (Bouzar et al., 1996; Jones et al., 2000; Stall et al., 1994; Vauterin et al., 1991; Vauterin et al., 1995). Atualmente, quatro grupos de Xanthomonas são reconhecidos como patogênicos ao tomateiro, resultando no complexo etiológico da mancha-bacteriana (Jones et al., 2000). Os grupos "A" e "C" correspondem a $X$. axonopodis pv. vesicatoria sensu Vauterin et al., $1995(=X$. vesicatoria sensu Jones et al., 2000 e Schaad et al., 2000), sendo o grupo "C", que foi reconhecido posteriormente (Bouzar et al., 1996), tratado como um subgrupo da espécie (Jones et al., 2000). Os grupos “B” e "D”, por sua vez, correspondem respectivamente a 
X. vesicatoria (=X. extiosa) e 'X. gardneri' (Bouzar et al., 1999; Jones et al., 2000; Schaad et al., 2000).

A ocorrência dessas espécies em lavouras de tomate para processamento industrial no país é pouco conhecida. Relatos preliminares apontaram a presença de $X$. axonopodis pv. vesicatoria (grupo "B”) no sub-médio São Francisco em 1996 (Quezado-Soares et al., 1997). Bouzar et al. (1994b) relataram a presença dos grupos " $A$ " e "B" entre isolados brasileiros de tomate e pimentão provenientes, em sua maioria, do estado do Paraná.

O conhecimento da diversidade genética de populações bacterianas tem experimentado grandes avanços nos últimos anos em decorrência da utilização de técnicas moleculares (Mengoni \& Bazzicalupo, 2002). O processamento da grande quantidade de informação gerada por sua vez, tem sido acompanhado pelo desenvolvimento de técnicas estatísticas específicas (Mengoni \& Bazzicalupo, 2002). A diversidade, tanto fenotípica como genética, de populações fitopatogênicas, tem sido avaliada através de índices de diversidade (McDonald \& Martinez, 1990; Goodwin et al., 1992; Xia et al., 1993) e, mais recentemente, de análises de agrupamento, de componentes principais e da análise molecular da variância - AMOVA (Adhikari et al., 1999; Ochiai et al., 2000).

Além de possibilitar inferências sobre a diversidade fenotípica/genotípica de populações, análises genéticas hierárquicas permitem revelar efeitos de variáveis independentes sobre variáveis dependentes em diferentes níveis populacionais considerados (Carelli et al., 2000; Dalmastri et al., 1999; Huff et al., 1993; Mengoni \& Bazzicalupo, 2002; Picard et al., 2000). Em geral, as questões mais freqüentes feitas acerca de populações fitopatogênicas estão relacionadas aos efeitos de cultivares e de variáveis micro e macro-geográficas (variáveis independentes) (Adhikari et al., 1999; Restrepo et al., 2000; Sicard et al., 1997). Nesse sentido, a AMOVA, desenvolvida por Excoffier et al. (1992), é uma ferramenta estatística que está cada vez mais sendo empregada para identificar componentes que contribuem para a divergência genética populacional (Mengoni \& Bazzicalupo, 2002). 
Os objetivos deste trabalho foram identificar os grupos genéticos presentes nas populações de Xanthomonas spp. associadas à mancha-bacteriana em campos de tomate para processamento industrial localizados nas macro-regiões produtoras Brasil-Central (estados de Goiás e Minas Gerais) e Nordeste (Pernambuco e Bahia) e verificar a associação de efeitos macro-geográficos e de tipo de variedade com a ocorrência desses grupos e com seus níveis de variabilidade genética.

\subsection{MATERIAL E MÉTODOS}

\subsubsection{Obtenção e procedência dos isolados}

Os procedimentos de coleta, isolamento e manutenção dos isolados foram descritos no item 3.2.1 do capítulo 3. Foram obtidos 447 isolados procedentes de duas macro-regiões produtoras de tomate para processamento industrial: 1) Brasil-Central, representada por municípios dos estados de Goiás e Minas Gerais e 2) Nordeste, por Pernambuco e Bahia (Tabela 1). A primeira região compreendeu campos de 20 a 50 ha, irrigados por aspersão, em geral, por pivô-central, cultivados em sua maioria com híbridos importados. Na segunda, os campos eram menores, em torno de 2 a 5 ha, irrigados por aspersão convencional ou sulco e cultivados predominantemente com a variedade nacional de polinização aberta IPA-5 (Tabela 1).

Em todas as análises os isolados 75-3, XV56 e XG101 foram incluídos como referência das espécies $X$. axonopodis pv. vesicatoria, $X$. vesicatoria e ' $X$. gardneri', pertencentes respectivamente aos grupos PFGE “A”, "B" e "D" (sensu Jones et al., 2000). 
Tabela 1. Local, ano e número de isolados coletados em campos comerciais de tomate para processamento industrial no Brasil-Central e Nordeste.

\begin{tabular}{|c|c|c|c|c|}
\hline Estado e município & Ano & Campo & Variedade $^{1}$ & $\begin{array}{l}\text { Número de } \\
\text { isolados }\end{array}$ \\
\hline \multicolumn{5}{|l|}{ Brasil-Central } \\
\hline \multirow[t]{4}{*}{ Itapaci-GO } & 1995 & 1 & Mistura de híbridos & 36 \\
\hline & & 2 & Mistura de híbridos & 22 \\
\hline & & 3 & Henz 9280 & 38 \\
\hline & & 4 & 401-8 & 46 \\
\hline \multirow[t]{3}{*}{ Itapaci-GO } & 1997 & 5 & $401-8$ & 9 \\
\hline & & 6 & Andino & 10 \\
\hline & & 7 & Topmech & 4 \\
\hline \multirow[t]{2}{*}{ Rio Verde-GO } & 1997 & 1 & Mistura de híbridos & 44 \\
\hline & & 2 & Santa Adelia & 3 \\
\hline \multirow[t]{3}{*}{ Morrinhos-GO } & 1998 & 1 & Hypeel 108, Hypeel 45 & 39 \\
\hline & & 2 & Hypeel 45, Rio Grande & 26 \\
\hline & & 3 & Petomech & 4 \\
\hline Morrinhos-GO & 2000 & 4 & $\begin{array}{c}\text { RPT } 1570 \text {, Hypeel 108, } \\
\text { Petoseed } 6914\end{array}$ & 65 \\
\hline Patos de Minas-MG & 1998 & 1 & $\begin{array}{c}\text { Viradoro, Ragu 9414, } \\
\text { Heinz } 9498\end{array}$ & 11 \\
\hline \multicolumn{5}{|l|}{ Nordeste } \\
\hline \multirow[t]{4}{*}{ Abaré-BA } & 1998 & 1 & IPA-5 & 5 \\
\hline & & 2 & IPA-5 & 5 \\
\hline & & 3 & IPA-5 & 5 \\
\hline & & 4 & IPA-5 & 4 \\
\hline Juazeiro-BA & 1998 & 1 & IPA-5 & 4 \\
\hline \multirow{2}{*}{ Orocó-PE } & 1998 & 1 & $\mathrm{U}-570$ & 8 \\
\hline & & 2 & $\mathrm{U}-570$ & 2 \\
\hline \multirow[t]{4}{*}{ Petrolina-PE } & 1996 & 1 & IPA-5 & 5 \\
\hline & & 2 & IPA-5 & 7 \\
\hline & & 3 & IPA-5 & 9 \\
\hline & & 4 & IPA-5 & 15 \\
\hline \multirow[t]{6}{*}{ Petrolina-PE } & 1998 & 5 & IPA-5 & 4 \\
\hline & & 6 & IPA-5 & 3 \\
\hline & & 7 & IPA-5 & 4 \\
\hline & & 8 & IPA-5 & 3 \\
\hline & & 9 & IPA-5 & 3 \\
\hline & & 10 & IPA-5 & 4 \\
\hline
\end{tabular}

1. Variedades Rio Grande, Topmech, Petomech, 401-8, Viradoro e IPA-5 são de polinização aberta, as demais híbridos. 401-8, Viradoro e IPA-5 são variedades nacionais. 


\subsubsection{Identificação dos isolados}

\subsubsection{Perfis de macrorestrição do DNA genômico por eletroforese de campo pulsado (PFGE)}

A extração do DNA genômico, digestão com a enzima $X b a \mathrm{I}$, corridas de eletroforese e fotodocumentação deram-se conforme descrito anteriormente (item 3.2.2, capítulo 3).

Como também realizado no capítulo 3, calculou-se os coeficientes de similaridades $\mathrm{S}$, a partir da conversão dos dados de restrição em dados binários (1 para presença e 0 para ausência do fragmento) de acordo com Nei \& Li, 1979:

$$
S=2 n_{\mathrm{xy}} /\left(n_{\mathrm{x}}+n_{\mathrm{y}}\right) \text { onde, }
$$

nxy representa o número de fragmentos maiores que $100 \mathrm{~kb}$ (Egel et al., 1991) comigrantes entre dois isolados ( $\mathrm{x}$ e $\mathrm{y}$ ) e nx e ny o número total de fragmentos maiores do que $100 \mathrm{~kb}$ para o isolado $\mathrm{x}$ e para o isolado $\mathrm{y}$, respectivamente. O pacote computacional NTSYS-pc (versão 1,70; Exeter Software, Setaukaat, NY, EUA) foi utilizado para os cálculos de similaridade. Esses dados foram submetidos à análise de agrupamento através do programa SAHN do mesmo pacote, empregando-se o método aritmético não ponderado de determinação de grupos (UPGMA), construindo-se também um dendrograma. Os limites de confiança dos grupos foram determinados pela análise de "bootstrap" (Graur \& Li, 2000) com 1.000 permutações, através do programa computacional BOOD (versão 1,0; A. S. G. Coelho, Laboratório de Genética Vegetal DBG/ICB/UFG, Goiânia, GO).

\subsubsection{Hidrólise de amido e pectato, utilização de maltose e eletroforese de proteínas solúveis}

Os testes de hidrólise de amido e de pectado foram realizados com todos os isolados, conforme descrito no item 3.2.4 do capítulo 3. Vinte e um isolados, em complementação aos 215 analisados no referido capítulo, foram testados quanto à capacidade de utilizar maltose como única fonte de carbono. Esses isolados representavam diferentes haplótipos PFGE e eventos de coleta. 
Dez isolados, além dos 21 referidos no mesmo capítulo, também foram caracterizados quanto aos seus perfis de proteínas pela separação em uma dimensão, utilizando-se metodologia descrita anteriormente (Bouzar et al., 1994a; Stall et al., 1994 [item 3.2.7]).

\subsubsection{Testes de patogenicidade}

Cento e sessenta e cinco isolados, complementando-se o grupo previamente inoculado conforme descrito no capítulo 3 (item 3.2.5), foram inoculados em plantas das cultivares não portadoras de genes de resistência, Walter (tomate) e Early Calwonder (pimentão). Os procedimentos utilizados foram os descritos no item mencionado.

\subsubsection{Análise da diversidade genética}

\subsubsection{Diversidade das populações quanto aos grupos PFGE}

Foram realizadas duas análises de diversidade populacional em relação aos grupos PFGE identificados no item 4.2.2.2, uma focalizando o efeito macro-geográfico e outra o de cultivares. Em cada análise, as populações foram estratificadas em três níveis hierárquicos:

1) Análise 1. Efeito da macro-geografia (Tabela 2):

1. Entre macro-regiões (= conjuntos)

2. Entre populações (localidade-ano) dentro de macro-regiões

3. Dentro de populações 
Tabela 2. Populações das macro-regiões $\mathrm{GO}+\mathrm{MG}$ e $\mathrm{PE}+\mathrm{BA}$ usadas na análise da diversidade de grupos PFGE.

\begin{tabular}{lclc}
\hline GO+MG & Número de isolados & PE+BA & Número de isolados \\
\hline 1. Itapaci-1995 & 142 & 1. Abaré-1998 & 19 \\
2. Itapaci-1997 & 23 & 2. Juazeiro-1998 & 4 \\
3. Rio Verde-1997 & 47 & 3. Orocó-1998 & 10 \\
4. Morrinhos-1998 & 69 & 4. Petrolina-1996 & 36 \\
5. Morrinhos-2000 & 65 & 5. Petrolina-1998 & 21 \\
6. Patos de Minas-1998 & 11 & & - \\
Total & 357 & Total & 90 \\
\hline
\end{tabular}

2) Análise 2. Efeito de cultivares. Esta análise foi realizada apenas com populações oriundas de campos cultivados com variedades híbridas importadas ou de polinização aberta sabidamente nacionais (Tabela 3). A estratificação deu-se nos seguintes níveis:

1. Entre tipos de variedade (= conjuntos)

2. Entre populações (variedade-localidade-ano) dentro de variedades

3. Dentro de populações

Tabela 3. Populações dos conjuntos de variedades híbridas importadas e de polinização aberta nacionais (PA) usadas na análise da diversidade de grupos PFGE.

\begin{tabular}{|c|c|c|c|}
\hline Híbridas & $\begin{array}{l}\text { Número de } \\
\text { isolados }\end{array}$ & Polinização Aberta & $\begin{array}{l}\text { Número de } \\
\text { isolados }\end{array}$ \\
\hline 1. Heinz 9280-Itapaci-1995 & 23 & 1. 401-8-Itapaci-1995 & 27 \\
\hline 2. Andino-Itapaci-1997 & 10 & 2. 401-8-Itapaci-1997 & 9 \\
\hline 3. Hypeel 108-Morrinhos-1998 & 19 & 3. Viradoro-Patos de Minas-1998 & 4 \\
\hline 4. Hypeel 45-Morrinhos-1998 & 36 & 4. IPA-5-Petrolina-1996 & 36 \\
\hline 5. Ragu 9414-Patos de Minas-1998 & 4 & 5. IPA-5-Petrolina-1998 & 21 \\
\hline 6. Heinz 9498-Patos de Minas-1998 & 3 & 6. IPA-5-Abaré-1998 & 19 \\
\hline 7. RPT 1570-Morrinhos-2000 & 8 & 7. IPA-5-Juazeiro-1998 & 4 \\
\hline 8. Hypeel 108-Morrinhos-2000 & 44 & - & - \\
\hline 9. Petoseed 6914-Morrinhos-2000 & 13 & - & - \\
\hline 10. U-570-Orocó-1998 & 10 & - & - \\
\hline Total & 170 & Total & 120 \\
\hline
\end{tabular}


As freqüências dos grupos PFGE foram então calculadas para cada população dos conjuntos de macro-regiões (análise 1, Tabela 2) e de tipos de variedade (análise 2, Tabela 3), bem como para cada macro-região, tipo de variedade e entre todos os isolados (total). Esses valores foram utilizados no cálculo do índice de de diversidade de Nei de 1975 (Xia et al., 1993):

$$
h=1-\sum \mathrm{x}_{j}^{2} \text { onde, }
$$

$\mathrm{x}_{j}$ representa a freqüência dos grupos PFGE.

A diversidade expressa na forma do índice de Nei citado acima foi decomposta nos diferentes estratos populacionais, considerando as fórmulas (Xia et al., 1993):

1) $h_{\mathrm{p}(\mathrm{c})=} h_{\mathrm{T} \mathrm{c}}-h_{\mathrm{i}(\mathrm{p} / \mathrm{c})} \mathrm{e}$

2) $h_{\mathrm{T}}=h_{\mathrm{i} \text { (média dos dois conjuntos) }}+h_{\mathrm{p} \text { (média dos dois conjuntos) }}$

onde,

$h_{\mathrm{p}(\mathrm{c})}$ representa a diversidade entre as populações do conjunto "c" (na análise 1, "c" podendo ser macro-região GO+MG ou PE+BA; na análise 2, híbrido ou PA); $h_{\mathrm{T} \mathrm{c}}$ a diversidade total do conjunto "c" e $h_{\mathrm{i}(\mathrm{p} / \mathrm{c})}$ a diversidade entre isolados dentro da população "p" do conjunto "c" e

$h_{\mathrm{T}}$ representa a diversidade total geral (na análise 1, abrangendo as duas macro-

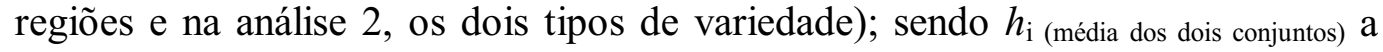
diversidade média geral entre isolados (na análise 1: média entre $h_{\mathrm{i}(\mathrm{p} / \mathrm{GO}+\mathrm{MG})}$ e $h_{\mathrm{i}}$

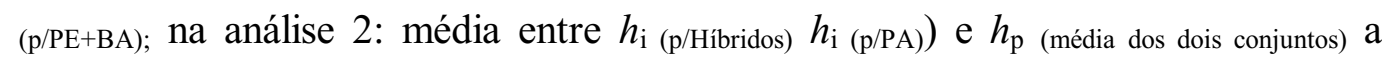
diversidade média geral entre populações (na análise 1: média entre $h_{\mathrm{p}(\mathrm{GO}+\mathrm{MG})} \mathrm{e}$ $h_{\mathrm{p}(\mathrm{PE}+\mathrm{BA})}$; na análise 2: média entre $h_{\mathrm{p}(\text { Hibridos })}$ e $\left.h_{\mathrm{p}(\mathrm{PA})}\right)$.

Calculou-se, ainda, as proporções da diversidade total explicadas por cada estrato. 


\subsubsection{Análise da variância molecular (AMOVA)}

A AMOVA foi empregada para estimar os componentes da variância da diversidade genética, decompondo-se esta em três níveis hierárquicos para as análises dos efeitos da macro-geografia e de cultivares, conforme descrito anteriormente (item 4.2.3.1). Além disso, analisou-se os dados separadamente das populações de $\mathrm{GO}+\mathrm{MG}$ e PE+BA (análise 1) e de híbridos e tipos de variedades (análise 2), a fim de comparar as proporções da variação entre populações e dentro das populações entre os conjuntos de cada análise.

A distância genética Euclidiana (métrica) foi computada a partir do número de fragmentos polimórficos entre dois haplótipos PFGE, para todos os pares de haplótipos, de acordo com a fórmula (Huff et al., 1993; Mengoni \& Bazzicalupo, 2002):

$$
E=n\left(1-2 n_{x y} / 2 n\right) \text { onde, }
$$

$n$ representa o número total de fragmentos e $n_{x y}$ o número de fragmentos em comum.

Para o cálculo das distâncias e realização da AMOVA, utilizou-se o programa computacional ARLEQUIN (versão 2000; S. Schneider, D. Roessli e L. Excoffier; Genetics and Biometry Laboratory, University of Geneva, Suíça). Os níveis de significância para as estimativas dos componentes da variância foram obtidos a partir de procedimentos não-paramétricos de permutação, empregando-se 10.000 ciclos (Excoffier et al., 1992; Restrepo et al., 2000; Sicard et al., 1997). Sob a hipótese nula, as amostras são consideradas como retiradas de uma população global, com a variação observada atribuída ao acaso (Excoffier et al., 1992). Para a obtenção de uma distribuição de nulidade de cada nível hierárquico, são realizados os seguintes esquemas de permutação: 1) "entre conjuntos" (macro-regiões ou tipos de variedade), permutandose haplótipos entre populações entre os conjuntos; 2) "entre populações dentro de conjunto", permutando-se haplótipos entre populações dentro de cada conjunto e 3) "dentro de populações", permutando-se haplótipos entre populações entre conjuntos. Um valor $P$ é calculado e indica a probabilidade de obter ao acaso, uma estimativa de 
variância do componente populacional mais extrema, para mais ou para menos, do que aquele observado (Excoffier et al., 1992). Quando a análise foi feita separadamente por conjuntos (macro-regiões $\mathrm{GO}+\mathrm{MG}, \mathrm{PE}+\mathrm{BA}$, variedades híbridas e PAs), a variância entre populações foi testada permutando-se haplótipos entre populações.

\subsection{RESULTADOS}

\subsubsection{Identificação dos isolados}

\subsubsection{Análise de PFGE}

A digestão do DNA genômico com a enzima $X b a$ I resultou em 11 a 16 fragmentos por isolado, sendo analisadas um total de 50 fragmentos. Foi possível distingüir 26 haplótipos entre os 447 isolados analisados que apresentaram perfis distintos dos isolados de referência. Os perfis dos haplótipos obtidos por campo são apresentados nas Figuras 1 a 4. Os perfis dos haplótipos dos isolados provenientes dos campos Itapaci-1995, Itapaci-1997, Rio Verde-1997, Morrinhos-1998 e 2000 e Patos de Minas-1998 foram previamente apresentados no capítulo 3 (Figura 1). Os haplótipos foram agrupados posteriormente em quatro grupos PFGE de acordo com seus coeficientes de similaridade (Figura 5). Esses grupos foram consistentes em mais de $68 \%$ dos ciclos de permutação (Figura 5). 


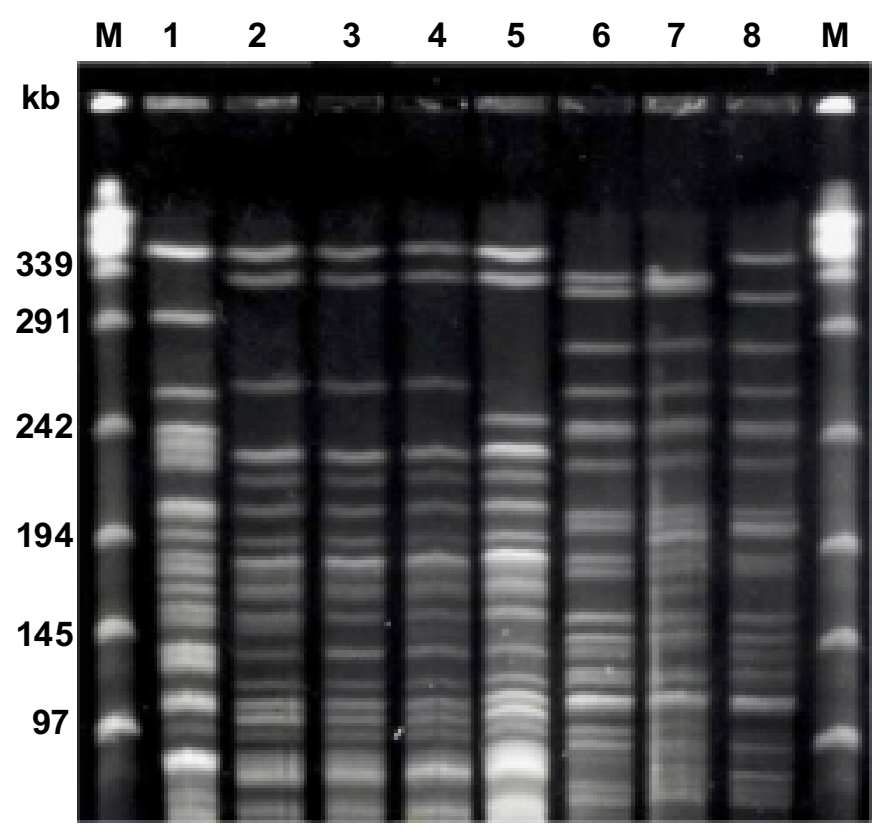

Figura 1 - Perfis de macrorestrição com a enzima XbaI de isolados de Xanthomonas spp. associadas à mancha bacteriana do tomateiro coletados em Itapaci, 1995. Poço M, marcador $\lambda$ DNA-PFGE (New England Biolabs, Beverly, MA). Poço 1, XV56 (X. vesicatoria); 2 a 5: CNPH10 (haplótipo h22), CNPH89 (h21), CNPH95 (h24) e CNPH108 (h23); 6, 75-3 (X. axonopodis pv. vesicatoria); $7 \mathrm{e}$ 8, CNPH109 (h8) e CNPH147 (h9). Pesos moleculares dados em kilobases. 


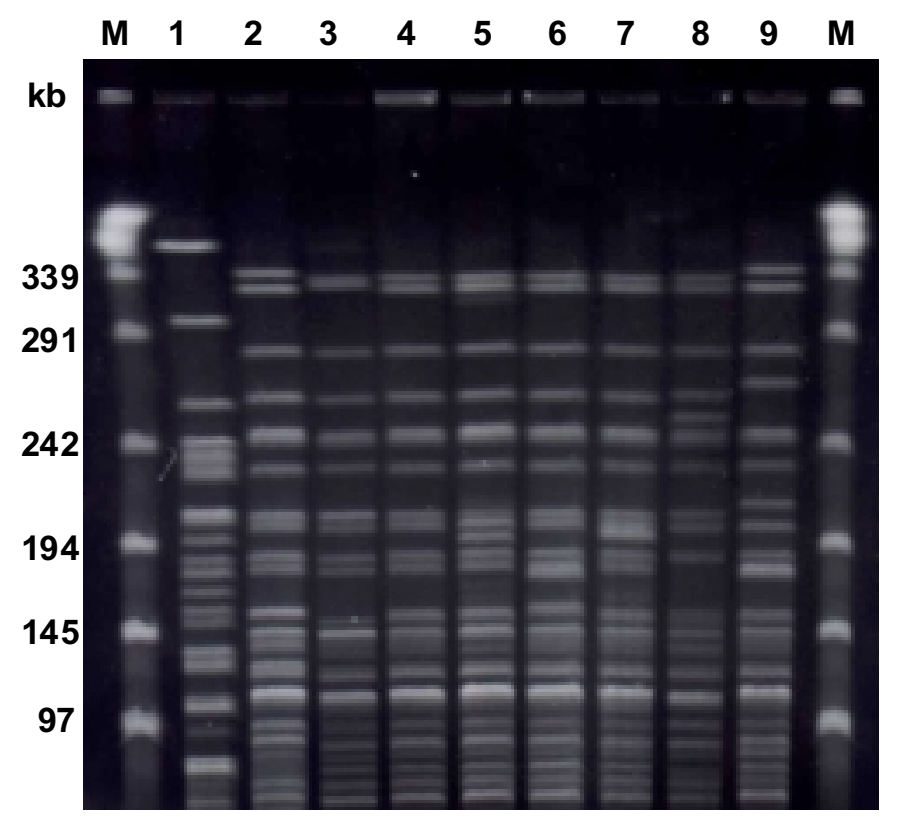

Figura 2 - Perfis de macrorestrição com a enzima XbaI de isolados de Xanthomonas spp. associadas à mancha bacteriana do tomateiro coletados em Petrolina, 1996. Poço M, marcador $\lambda$ DNA-PFGE (New England Biolabs, Beverly, MA). Poços 1 e 2, XV56 (X. vesicatoria) e 75-3 (X. axonopodis pv. vesicatoria); 2 a 5: CNPH213 (h4), CNPH216 (h1), CNPH229 (h7), CNPH215 (h3), CNPH235 (h2), CNPH226 (h5) e CNPH210 (h6). Pesos moleculares dados em kilobases. 


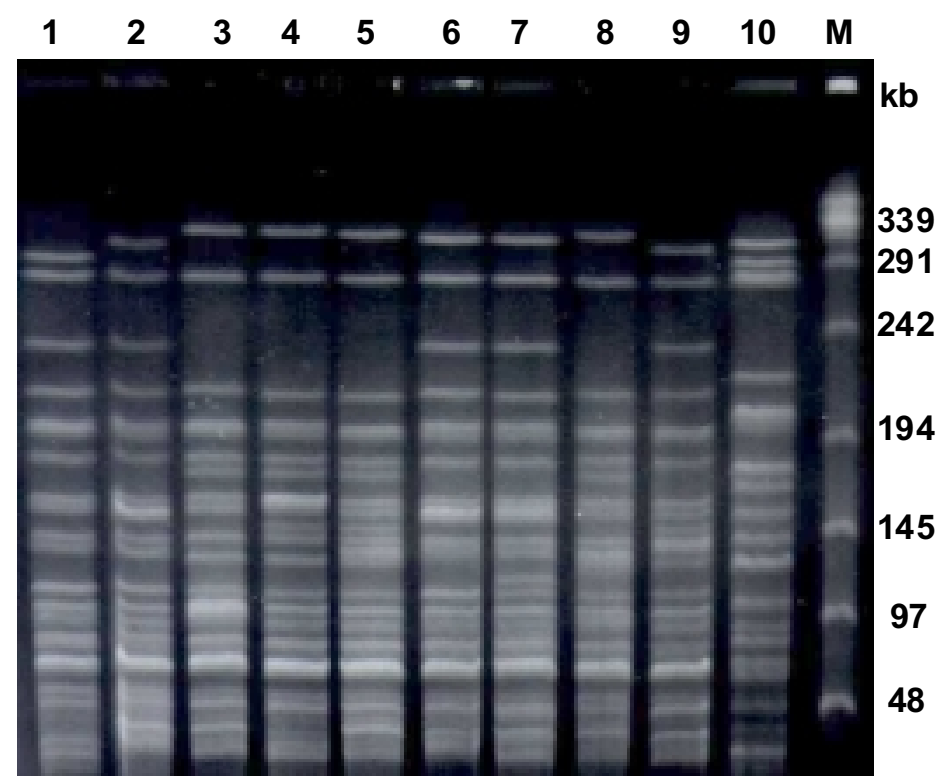

Figura 3 - Perfis de macrorestrição com a enzima XbaI de isolados de Xanthomonas spp. associadas à mancha bacteriana do tomateiro coletados em Abaré, 1996. Poço M, marcador $\lambda$ DNA-PFGE (New England Biolabs, Beverly, MA). Poços 1 e 2, XV56 (X. vesicatoria) e 75-3 (X. axonopodis pv. vesicatoria); 2 a 5: CNPH10 (haplótipo h22), CNPH89 (h21), CNPH95 (h24) e CNPH108 (h23); 6, 75-3 (7 e 8, CNPH109 (h8) e CNPH147 (h9). Pesos moleculares dados em kilobases. 


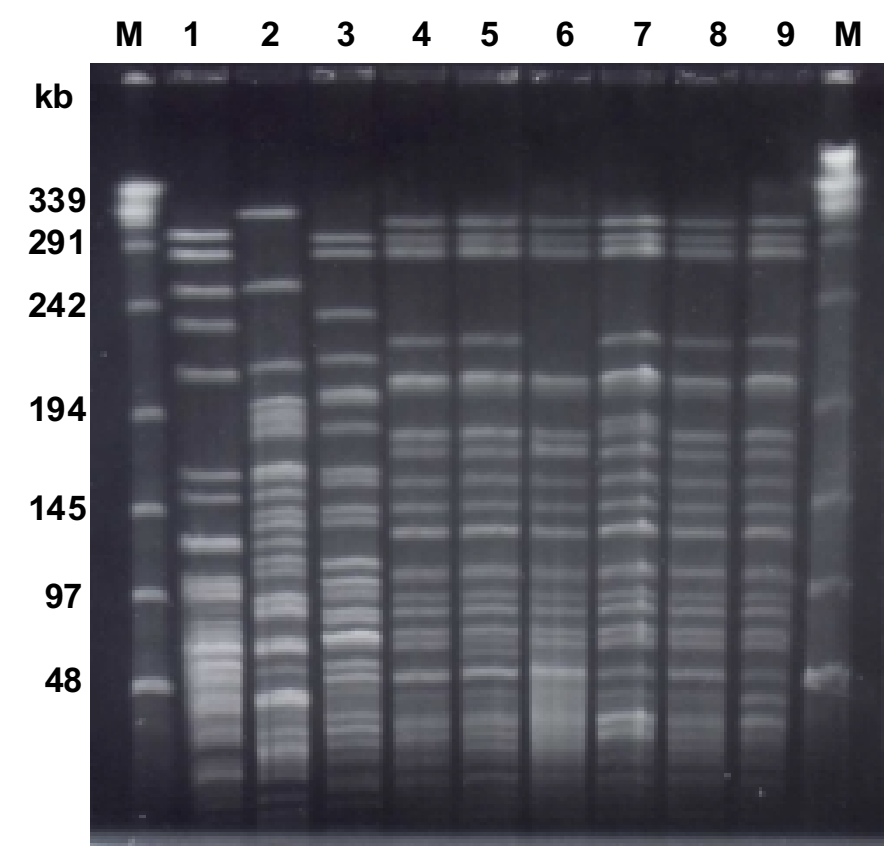

Figura 4 - Perfis de macrorestrição com a enzima XbaI de isolados de Xanthomonas spp. associadas à mancha bacteriana do tomateiro coletados em Petrolina, 1998, Orocó, 1998 e Juazeiro, 1998. Poço M, marcador $\lambda$ DNA-PFGE (New England Biolabs, Beverly, MA). Poços 1, 2 e 3, XG101 ('X. gardneri'), XV56 (X. vesicatoria) e 75-3 (X. axonopodis pv. vesicatoria); 4 a 9: CNPH429 (h18), CNPH431 (h18), CNPH440 (h19), CNPH445 (h20), CNPH452 (h18) de Orocó e CNPH582 (h18) de Juazeiro. Pesos moleculares dados em kilobases. 


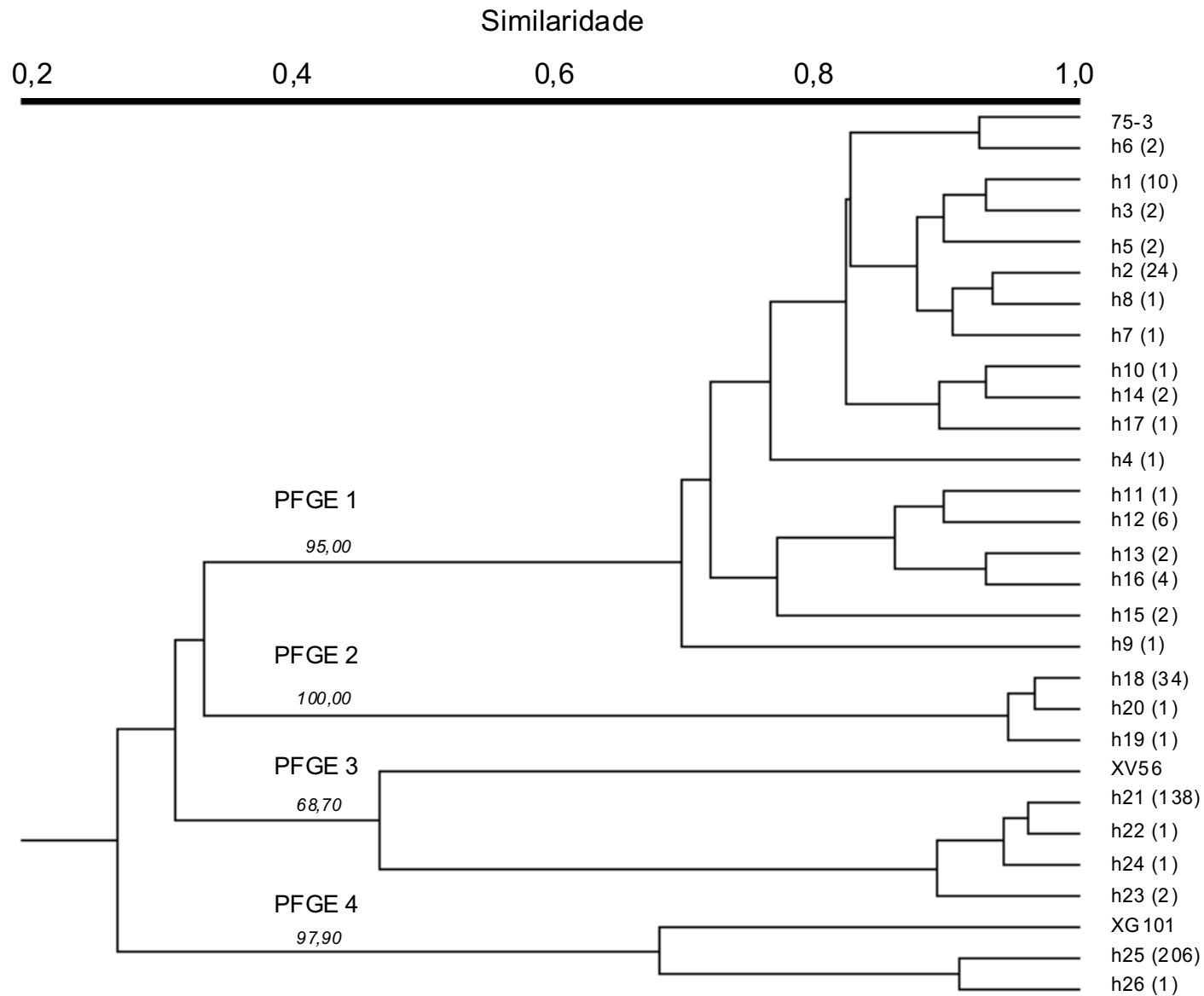

Figura 5. Dendrograma de haplótipos de Xanthomonas spp associadas à manchabacteriana do tomateiro determinados pelos perfis de macrorestrição com XbaI. Números em itálico indicam o número de vezes (em porcentagem) em que os haplótipos se agruparam naquele ponto após 1.000 permutas. $\mathrm{O}$ número de isolados apresentando o mesmo perfil aparece entre parênteses após o código do perfil. 
O número de haplótipos por grupo PFGE foi variável, bem como os coeficientes de similaridade entre haplótipos do mesmo grupo e entre grupos (Tabelas 4 e 5).

Tabela 4. Resumo dos dados obtidos pela análise de agrupamento.

\begin{tabular}{cccc}
\hline Grupo PFGE & Isolado de referência $^{1}$ & Número de haplótipos & $\begin{array}{c}\text { Intervalo de similaridade do } \\
\text { grupo }^{2}\end{array}$ \\
\hline 1 & $75-3$ & 17 & 0,62 a 0,93 \\
2 & não há & 3 & 0,93 a 0,97 \\
3 & XV56 & 4 & 0,46 a 0,96 \\
4 & XG101 & 2 & 0,64 a 0,91 \\
Total & - & 26 & - \\
\hline
\end{tabular}

1. 75-3: Xanthomonas axonopodis pv. vesicatoria (grupo fenotípico "A" sensu Stall et al., 1994; grupo PFGE “A” sensu Jones et al., 2000); XV56: X. vesicatoria (grupo fenotípico “B”; PFGE B) e XG101: “ X. gardneri' (grupo fenotípico " $D$ " e PFGE "D").

2. Coeficientes de similaridade de Nei \& Li, 1979.

Tabela 5. Coeficientes de similaridade mínimo e máximo entre isolados de grupos PFGE calculados segundo Nei \& Li, 1979.

\begin{tabular}{ccccc}
\hline Grupos PFGE & 1 & 2 & 3 & 4 \\
\hline 1 & - & - & - & - \\
2 & 0,214 a 0,519 & - & - & - \\
3 & 0,214 a 0,462 & 0,154 a 0,296 & - & - \\
4 & 0,240 a 0,417 & 0,077 a 0,250 & 0,167 a 0,333 & - \\
\hline
\end{tabular}

\subsubsection{Características fenotípicas}

As características fenotípicas foram uniformes entre isolados pertencentes ao mesmo grupo PFGE conforme apresentado na Tabela 6. 
Tabela 6. Resumo das características fenotípicas ${ }^{1}$ dos grupos PFGE.

\begin{tabular}{ccccccc}
\hline Grupo PFGE & AM & PEC & MAL & Proteína & TOM & PIM \\
\hline 1 & -2 & - & + & $\propto$ & + & + \\
2 & + & + & + & $\beta$ & + & - \\
3 & + & + & + & $\beta$ & + & - \\
$4^{3}$ & - & - & - & $\beta$ & + & $\mathrm{v}$
\end{tabular}

1. AM: atividade amidolítica; PEC: atividade pectolítica; MAL: utilização de maltose como única fonte de carbono; Proteína: presença de banda típica acizentada de 32k-Da $(\propto)$ ou 27k-Da (ß); TOM: patogenicidade a cv. Walter de tomate; PIM: idem à cv. EarlyCalwonder de pimentão.

2. +: teste deu resultado positivo; -: resultado negativo; "v": variável.

3. Resultados referentes aos isolados desse grupo foram apresentados no capítulo 3.

Com base nas características genotípicas e fenotípicas apresentadas anteriormente, os isolados do grupo PFGE 1 foram classificados como $X$. axonopodis pv. vesicatoria, do grupo PFGE 3, como $X$. vesicatoria e do grupo PFGE 4, 'Xanthomonas gardneri'. Os isolados do grupo PFGE 2 não puderam ser classificados quanto à espécie por terem se agrupado distintamente dos isolados de referência, estando, no entanto, mais próximo do grupo PFGE 1 do que dos demais. Além disso, as características fenotípicas observadas são indistintas entre isolados desse grupo e do grupo PFGE 3 (Tabela 6). Considerações sobre esse grupo são feitas no capítulo 5.

\subsubsection{Análise da diversidade genética}

\subsubsection{Distribuição e diversidade de grupos PFGE/espécies}

A ocorrência dos quatro grupos de PFGE variou de acordo com macro-regiões. O grupo 1, por exemplo, foi o único que ocorreu em ambas macro-regiões. Já os grupos 3 e 4 ocorreram apenas no Brasil Central e o 2, apenas no Nordeste (Figura 6A). Considerando o tipo de variedade (híbridas importadas ou de polinização aberta), os quatro grupos ocorreram em ambos, sendo que nas variedades híbridas predominou o grupo PFGE 4 e nas de polinização aberta o grupo PFGE 1 (Figura 6B). 


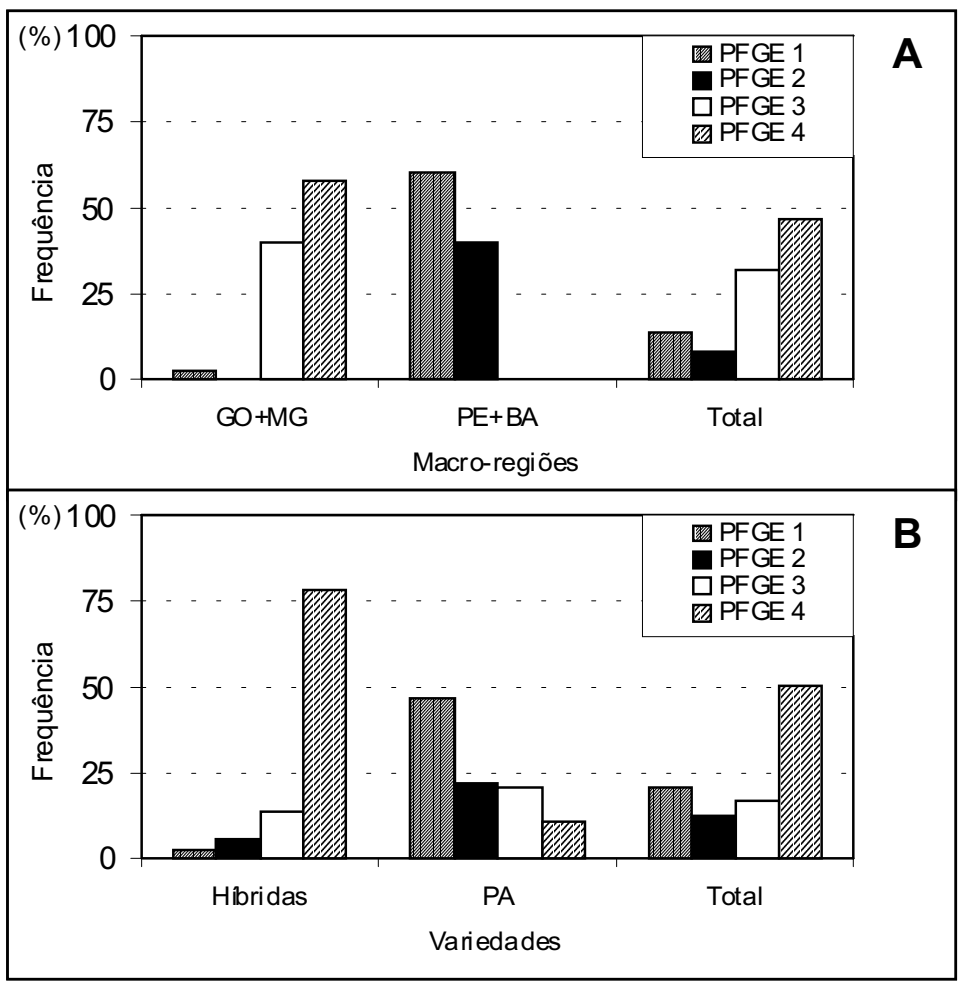

Figura 6 - (A) Freqüência em porcentagem de grupos PFGE nas regiões produtoras do Brasil-Central (GO+MG) e do Nordeste (PE+BA) e na amostra total de isolados. (B) Idem em variedades híbridas importadas e de polinização aberta nacionais (PA). PFGE 1, 3 e 4 correspondem, respectivamente às espécies Xanthomonas axonopodis pv. vesicatoria, $X$. vesicatoria e ' $X$. gardneri'; PFGE 2, ainda não classificado quanto à espécie.

As freqüências dos grupos PFGE e os índices de diversidade genética de Nei de cada população são apresentadas nas Tabela 7 e 9, respectivamente para as análises dos efeitos de macro-geografia e de variedades. $\mathrm{Na}$ análise da macro-geografia, os índices $h$ de Nei das populações tanto de $\mathrm{GO}+\mathrm{MG}$ como de $\mathrm{PE}+\mathrm{BA}$ foram baixos, indicando a 
baixa diversidade de grupos PFGE presentes dentro de cada população (Tabela 7 e 8). Essa variação intra-populacional correspondeu à menor proporção da variação total de grupos PFGE, enquanto que a diversidade entre populações abrangeu a maior proporção (Tabela 8). Na análise de variedades também verificou-se baixa diversidade de grupos nas populações de variedades híbridas e de polinização aberta (Tabela 9 e 10). Esse componente populacional também abrangeu a menor proporção da diversidade total e o componente da diversidade entre populações, a maior proporção (Tabela 10).

Tabela 7. Freqüências dos grupos PFGE por populações (localidades-ano) e por macroregiões produtoras e seus respectivos índices de diversidade de Nei, $h$.

\begin{tabular}{lcccccc}
\hline Populações & $\begin{array}{c}\text { Tamanho da } \\
\text { amostra }\end{array}$ & PFGE 1 & PFGE 2 & PFGE 3 & PFGE 4 & $h$ \\
\hline Brasil-Central & & & & & & \\
1. ITA-1995 & 142 & 0,014 & 0,000 & 0,986 & 0,000 & 0,028 \\
2. ITA-1997 & 23 & 0,000 & 0,000 & 0,087 & 0,913 & 0,160 \\
3. RV-1997 & 47 & 0,000 & 0,000 & 0,000 & 1,000 & 0,000 \\
4. MOR-1998 & 69 & 0,087 & 0,000 & 0,000 & 0,913 & 0,160 \\
5. MOR-2000 & 65 & 0,000 & 0,000 & 0,000 & 1,000 & 0,000 \\
6. PAT-1998 & 11 & 0,000 & 0,000 & 0,000 & 1,000 & 0,000 \\
Nordeste & & & & & & \\
7. ABA-1998 & 19 & 0,947 & 0,053 & 0,000 & 0,000 & 0,100 \\
8. JUA-1998 & 4 & 0,000 & 1,000 & 0,000 & 0,000 & 0,000 \\
9. ORO-1998 & 10 & 0,000 & 1,000 & 0,000 & 0,000 & 0,000 \\
10. PET-1996 & 36 & 1,000 & 0,000 & 0,000 & 0,000 & 0,000 \\
11. PET-1998 & 21 & 0,000 & 1,000 & 0,000 & 0,000 & 0,000 \\
Brasil-Central & 357 & 0,022 & 0,000 & 0,398 & 0,580 & 0,505 \\
Nordeste & 90 & 0,600 & 0,400 & 0,000 & 0,000 & 0,480 \\
TOTAL & 447 & 0,139 & 0,080 & 0,318 & 0,463 & 0,659 \\
\hline
\end{tabular}


Tabela 8. Índices de diversidade de Nei, $h$, e porcentagem da diversidade total nos diferentes níveis da hierarquia populacional da análise macro-geográfica.

\begin{tabular}{lcccccc}
\hline Níveis hierárquicos & \multicolumn{2}{c}{ GO+MG } & \multicolumn{2}{c}{ PE+BA } & \multicolumn{2}{c}{ Total } \\
& $h$ & $\%$ & $h$ & $\%$ & $h$ & $\%$ \\
\hline 1. Dentro das populações $\left(h_{\mathrm{i}}\right)$ & 0,058 & 11,5 & 0,020 & 4,2 & 0,039 & 5,9 \\
2. Entre as populações $\left(h_{\mathrm{p}}\right)$ & 0,447 & 88,5 & 0,460 & 95,8 & 0,454 & 68,9 \\
3. Entre os grupos $\left(h_{\mathrm{g}}\right)$ & - & - & - & - & 0,166 & 25,2 \\
Total $\left(h_{\mathrm{T} \mathrm{g}} \mathrm{e} h_{\mathrm{T}}\right)$ & 0,505 & 100 & 0,480 & 100 & 0,659 & 100 \\
\hline
\end{tabular}

Tabela 9. Freqüências dos grupos PFGE por populações (variedade-localidades-ano) e tipos de variedades plantadas e seus respectivos índices de diversidade de Nei, $h$.

\begin{tabular}{lcccccc}
\hline Populações & $\begin{array}{c}\text { Tamanho } \\
\text { da amostra }\end{array}$ & PFGE 1 & PFGE 2 & PFGE 3 & PFGE 4 & $h$ \\
\hline Híbridas importadas & & & & & & \\
1. Heinz 9280/Itapaci-1995 & 23 & 0,000 & 0,000 & 1,000 & 0,000 & 0,000 \\
2. Andino/Itapaci-1997 & 10 & 0,000 & 0,000 & 0,000 & 1,000 & 0,000 \\
3. Hypeel 108/Morrinhos-1998 & 19 & 0,053 & 0,000 & 0,000 & 0,947 & 0,100 \\
4. Hypeel 45/Morrinhos-1998 & 36 & 0,083 & 0,000 & 0,000 & 0,917 & 0,153 \\
5. Ragu 9414/Patos-1998 & 4 & 0,000 & 0,000 & 0,000 & 1,000 & 0,000 \\
6. Heinz 9498/Patos-1998 & 3 & 0,000 & 0,000 & 0,000 & 1,000 & 0,000 \\
7. RPT 1570/Morrinhos-2000 & 8 & 0,000 & 0,000 & 0,000 & 1,000 & 0,000 \\
8. Hypeel 108/Morrinhos-2000 & 44 & 0,000 & 0,000 & 0,000 & 1,000 & 0,000 \\
9. Petoseed 6914/Morrinhos-2000 & 13 & 0,000 & 0,000 & 0,000 & 1,000 & 0,000 \\
10. U-570/Orocó-1998 & 10 & 0,000 & 1,000 & 0,000 & 0,000 & 0,000 \\
Polinização aberta nacional & & & & & & \\
11. 401-8/Itapaci-1995 & 27 & 0,074 & 0,000 & 0,926 & 0,000 & 0,137 \\
12. 401-8/Itapaci-1997 & 9 & 0,000 & 0,000 & 0,000 & 1,000 & 0,000 \\
13. Viradoro/Patos-1998 & 4 & 0,000 & 0,000 & 0,000 & 1,000 & 0,000 \\
14. IPA-5/Petrolina-1996 & 36 & 1,000 & 0,000 & 0,000 & 0,000 & 0,000 \\
15. IPA-5/Petrolina-1998 & 21 & 0,000 & 1,000 & 0,000 & 0,000 & 0,000 \\
16. IPA-5/Abaré-1998 & 19 & 0,947 & 0,053 & 0,000 & 0,000 & 0,100 \\
17. IPA-5/Juazeiro-1998 & 4 & 0,000 & 1,000 & 0,000 & 0,000 & 0,000 \\
Híbridas importadas & 170 & 0,024 & 0,059 & 0,135 & 0,782 & 0,366 \\
Polinização aberta nacionais & 120 & 0,467 & 0,217 & 0,208 & 0,108 & 0,680 \\
TOTAL & 290 & 0,207 & 0,124 & 0,166 & 0,503 & 0,661 \\
\hline
\end{tabular}


Tabela 10. Índices de diversidade de Nei, h, e porcentagem da diversidade total nos diferentes níveis da hierarquia populacional da análise de variedades.

\begin{tabular}{lcccccc}
\hline Níveis hierárquicos & \multicolumn{2}{c}{ Híbridas } & \multicolumn{2}{c}{$\mathrm{PA}^{1}$} & \multicolumn{2}{c}{ Total } \\
& $h$ & $\%$ & $h$ & $\%$ & $h$ & $\%$ \\
\hline 1. Dentro das populações $\left(h_{\mathrm{i}}\right)$ & 0,025 & 6,8 & 0,034 & 5,0 & 0,030 & 4,5 \\
2. Entre as populações $\left(h_{\mathrm{p}}\right)$ & 0,341 & 93,2 & 0,646 & 95,0 & 0,494 & 74,7 \\
3. Entre os tipos de variedade $\left(h_{\mathrm{g}}\right)$ & - & - & - & - & 0,137 & 20,7 \\
Total $\left(h_{\mathrm{T} g}\right.$ e $h_{\mathrm{T}}$ ) & 0,366 & 100 & 0,680 & 100 & 0,661 & 100 \\
\hline 1. PA: variedade de polinização aberta. & & & & & &
\end{tabular}

1. PA: variedade de polinização aberta.

\subsubsection{Análise da variância molecular (AMOVA)}

Através da AMOVA verificou-se a porcentagem da variabilidade genética entre isolados atribuída a cada um dos três níveis hierárquicos estabelecidos nas duas análises (macro-geografia e variedades), bem como a sua significância (Tabelas 11 e 12). Diferenças significativas $(P<0,05)$ foram encontradas para os três componentes da variância populacional nas duas análises (Tabelas 11 e 12). Na análise dos dados separados por macro-regiões, GO+MG apresentou maior variação "dentro" de populações do que PE+BA (Tabela 13). Da mesma forma, maior variação "dentro" de populações do conjunto de híbridos foi verificada em relação ao conjunto de variedades PA nacionais (Tabela 14).

Tabela 11. Resultado da AMOVA considerando as populações nas macro-regiões produtoras $\mathrm{GO}+\mathrm{MG}$ e $\mathrm{PE}+\mathrm{BA}$.

\begin{tabular}{lccc}
\hline Fonte de variação & $\begin{array}{c}\text { \% da variação } \\
\text { total }\end{array}$ & $\begin{array}{c}\text { Componentes da } \\
\text { variância }\end{array}$ & Valor de $P$ \\
\hline Entre macro-regiões & 30,6 & 2,815 & 0,00188 \\
$\begin{array}{l}\text { Entre populações dentro de } \\
\text { macro-regiões }\end{array}$ & 62,8 & 5,780 & $<0,00001$ \\
Dentro de populações & 6,6 & 0,690 & $<0,00001$ \\
\hline
\end{tabular}


Tabela 12. Resultado da AMOVA considerando as populações em variedades híbridas importadas e de polinização aberta nacionais.

\begin{tabular}{lccc}
\hline Fonte de variação & $\begin{array}{c}\text { \% da variação } \\
\text { total }\end{array}$ & $\begin{array}{c}\text { Variância dos } \\
\text { componentes }\end{array}$ & Valor de $P$ \\
\hline $\begin{array}{l}\text { Entre tipos de variedade } \\
\text { Entre populações dentro de tipos } \\
\text { de variedade }\end{array}$ & 24,4 & 1,904 & $<0,00001$ \\
Dentro de populações & 66,5 & 5,189 & $<0,00001$ \\
\hline
\end{tabular}

Tabela 13. Resultado das AMOVAs considerando as macro-regiões produtoras $\mathrm{GO}+\mathrm{MG}$ e PE+BA separadamente.

\begin{tabular}{lccc}
\hline Fonte de variação & $\begin{array}{c}\text { \% da variação } \\
\text { total }\end{array}$ & $\begin{array}{c}\text { Variância dos } \\
\text { componentes }\end{array}$ & Valor de $P$ \\
\hline Entre populações de GO+MG & 92,1 & 5,719 & $<0,00001$ \\
Dentro de GO+MG & 7,2 & 0,488 & - \\
Entre populações de PE+BA & 84,7 & 6,010 & $<0,00001$ \\
Dentro de PE+BA & 15,3 & 1,086 & - \\
\hline
\end{tabular}

Tabela 14. Resultado das AMOVAs considerando variedades híbridas importadas e de polinização aberta (PA) nacionais separadamente.

\begin{tabular}{lccc}
\hline Fonte de variação & $\begin{array}{c}\text { \% da variação } \\
\text { total }\end{array}$ & $\begin{array}{c}\text { Variância dos } \\
\text { componentes }\end{array}$ & Valor de $P$ \\
\hline $\begin{array}{l}\text { Entre populações em variedades } \\
\text { híbridas }\end{array}$ & 90,1 & 3,736 & $<0,0000$ \\
Dentro de Híbridas & 9,9 & 0,411 & - \\
Entre populações em variedades PA & 86,7 & 7,367 & $<0,0000$ \\
Dentro de PA & 13,3 & 1,131 & - \\
\hline
\end{tabular}

\subsection{DISCUSSÃO}

Uma visão global da ocorrência de espécies de Xanthomonas associadas à mancha-bacteriana do tomateiro rasteiro no Brasil no período de 1995 a 2000 foi obtida através da análise de perfis PFGE e de características fenotípicas de mais de 400 isolados. A maioria dos isolados foi classificada em nível de espécie, encontrando-se 
isolados pertencentes às espécies $X$. axonopodis pv. vesicatoria (PFGE "A"), $X$. vesicatoria (PFGE “B”) e 'X. gardneri' (PFGE “D”) (Jones et al., 2000), que corresponderam, respectivamente, aos grupos PFGE 1, 3 e 4. Nenhum isolado de campo apresentou o mesmo haplótipo dos isolados de referência, indicando tratarem-se de linhagens distintas.

A classificação dos isolados do grupo PFGE 2, no entanto, não foi possível pois o grupo não englobou nenhum isolado de referência. Apesar das características fenotípicas do referido grupo serem semelhantes às do grupo 3 (PFGE "B" sensu Jones et al., 2000), os perfis genômicos de seus haplótipos foram mais semelhantes aos do grupo 1 (X. axonopodis pv. vesicatoria). Até o presente, quatro grupos genotípicos distintos foram descritos para Xanthomonas causadoras de mancha-bacteriana do tomateiro (Jones et al., 1998a; Jones et al., 2000). Presença da banda ß, atividades amidolíticas e pectolíticas e patogenicidade apenas ao tomateiro, conforme observado para isolados do grupo PFGE 2, são também características do grupo PFGE “C" (Jones et al., 1998a; Jones et al., 2000). A utilização de maltose não tem sido considerada (Jones et al, 1998b; Jones et al., 2000). Testes de hibridização e homologia de seqüências do RNA deram evidências de que esse grupo, identificado primeiramente no México (Bouzar et al., 1996), seria um subgrupo genético de X. axonopodis pv. vesicatoria (Jones et al., 2000). Dessa forma, é provável que o grupo PFGE 2 aqui identificado corresponda a esse subgrupo. Porém, esse resultado carece de comprovação por comparação com algum isolado de referência.

Menor similaridade entre os isolados de campo e os isolados de referência foi observada para o grupo 3, correspondente à $X$. vesicatoria, o que pode ser atribuído à considerável variabilidade existente dentro dessa espécie (Jones et al., 2000).

A ocorrência de quatro grupos PFGE, que correspondem genetica e fenotipicamente aos quatro descritos na literatura, resultou em um índice de diversidade elevado $\left(\mathrm{h}_{\mathrm{T}}=0,660\right)$. Não se tem conhecimento de tal diversidade de grupos de Xanthomonas associadas à mancha-bacteriana do tomateiro em outro local (Jones et al., 1998a). Bouzar et al. (1999), por exemplo, relataram apenas a ocorrência de $X$. 
axonopodis pv. vesicatoria (grupo "A") no Caribe e dessa espécie e de 'X. gardneri' na América Central (grupo “D”).

Neste estudo investigou-se também o efeito da macro-região sobre a estrutura populacional em termos de diversidade de espécies/grupos do complexo causador da mancha-bacteriana, haja vista a nítida distinção entre os sistemas de cultivo e condições edafoclimáticas do Nordeste e do Brasil-Central (Barbosa, 1997). Uma vez que uma das diferenças mais evidentes entre os referidos sistemas de cultivos no período analisado era o tipo de variedade plantada, com híbridos predominando no Brasil-Central e a PA IPA-5 no Nordeste, uma segunda análise também foi estabelecida para verificar o efeito desse fator.

Diferenças em freqüências de espécies/grupos PFGE foram bastante evidentes entre macro-regiões e, em menor extensão, entre tipos de variedade. Esse fato pode ser reflexo de um reduzido fluxo genético entre as macro-regiões que, por sua vez, pode sr devido ao reduzido trânsito de material vegetal entre elas. No entanto, alguns plantios esporádicos de IPA-5, a variedade tradicionalmente plantada no Nordeste, e mais recentemente de Viradoro, ambas desenvolvidas pelo Instituto de Pesquisa Agropecuária de Pernambuco, já foram estabelecidos no Brasil-Central. Isso pode explicar a ocorrência no Brasil Central das duas linhagens de $X$. axonopodis pv. vesicatoria, mais freqüentes no Nordeste. Em relação à diversidade total nas duas macro-regiões, os respectivos índices $h_{\mathrm{Tg}}$ foram muito próximos $(0,51$ e 0,48 , para $\mathrm{GO}+\mathrm{MG}$ e $\mathrm{PE}+\mathrm{BA}$ respectivamente), já que cada macro-região apresentou a nítida predominância de dois grupos PFGE (Figura 6). Já na análise do efeito do tipo de variedade, a diversidade total foi superior em isolados oriundos das variedades PA nacionais. Considerando os dois conjuntos de populações de cada análise (macro-geografia e tipo de variedade), maior diversidade total de espécies/grupos PFGE foi encontrada para o componente "entre populações dentro de macro-regiões ou tipos de variedade" (aproximadamente 69 \% para macro-regiões e $75 \%$ para tipos de variedade) e menor para o componente "dentro das populações" (cerca de $6 \%$ e $5 \%$, respectivamente para macro-regiões e tipos de variedade). De fato, como já mencionado, as populações eram em geral compostas por uma única espécie/grupo. 
Apenas recentemente estudos de biodiversidade intra-específica de microorganismos têm sido realizados visando o melhor entendimento de dinâmicas populacionais e suas relações com diversos fatores de interesse tais como solo, cultivares, etc. (Carelli et al., 2000; Dalmastri et al., 1999; Picard et al., 2000; Restreppo et al., 2000). Neste trabalho, em termos de diversidade haplotípica (intra-específica), quando a AMOVA foi realizada com os dados totais para macro-região ou tipo de variedade, as proporções da variação genética atribuídas aos componentes da hierarquia populacional foram relativamente semelhantes aos da análise da diversidade das espécies/grupos PFGE através dos índices de diversidade de Nei. Porém, a AMOVA, através dos procedimentos de permutação, apontou que as variâncias observadas nos três níveis hierárquicos foram significativamente diferentes daquelas esperadas se as amostras populacionais fizessem parte de um conjunto populacional global (Excoffier et al., 1992). Ambos resultados apontaram para a baixa variação intra-populacional, indicando que as populações, além de serem compostas por apenas uma a duas espécies/grupos PFGE, eram em geral clonais. Do mesmo modo, maior proporção da variação genética foi atribuída ao componente inter-populacional tanto na análise da macro-região como do tipo de variedade, mas variação considerável também existiu entre as macro-regiões $(30,6 \%)$ e entre os tipos de variedade $(24,4 \%)$. Na verdade, os efeitos dessas duas variáveis estão confundidos, já que cada tipo de variedade predominou em cada macro-região.

Estudos da diversidade de grupos RFLP do fungo Magnaporthe grisea (Xia et al., 1993) entre dois campos nos EUA e da diversidade patogênica de Rhynchosporium secalis entre localidades também nos EUA (Goodwin et al., 1992), indicaram que a maior proporção da diversidade foi devida ao nível mais inferior de estratificação ("dentro das populações") e, portanto, as populações não eram clonais. Fato semelhante também foi observado em $X$. axonopodis pv. manihotis quando a decomposição da análise da variância realizada através da AMOVA atestou diferenças altamente significativas em todos os níveis hierárquicos (zonas edafoclimáticas e localidades dentro das zonas), com maior variação atribuída ao componente intra-populacional (Restrepo et al., 2000). Da mesma forma, populações de Burkholderia cepacia, isoladas 
da rizosfera de milho (Zea mays L.) mostraram-se altamente diversas (Dalmastri et al., 1999). Seria interessante associar o nicho ecológico e patogênico das bactérias fitopatogênicas à diversidade genética já que alguns autores, segundo Dalmastri et al. (1999), associam essa diversidade à capacidade adaptativa bacteriana em ambientes heterogêneos como o solo. Então menor diversidade para bactérias "invasoras do solo", que sobrevivem no solo somente enquanto existe tecido da hospedeira não-decomposto, como as Xanthomonas associadas à mancha-bacteriana, comparado às bactérias habitantes do solo (Agrios, 1997), como Burkholderia.

Os efeitos da macrogeografia e do tipo de variedade na diversidade populacional de Xanthomonas, não obstante, foram mais claramente observados quando os conjuntos foram analisados separadamente. Os isolados provenientes de uma mesma população obtidos de cultivares híbridas importadas foram menos variáveis entre si do que os provenientes de variedades de polinização aberta (PA) nacionais; do mesmo modo que os provenientes do Brasil-Central o foram em relação ao Nordeste. Esse fato se explica pela predominância entre variedades PA nacionais e no Nordeste, de isolados pertencentes ao grupo PFGE 1, que apresentou-se mais polimórfico, em oposição à predominância dos grupos 3 e 4, menos variáveis, entre as populações das variedades híbridas e do Brasil-Central. Diferentemente, Restrepo et al. (2000) encontraram maior diversidade entre populações de $X$. axonopodis pv. manihotis isoladas de variedades de mandioca (Manihot esculenta Crantz) melhoradas do que entre variedades locais, porém, o fato foi atribuído ao maior número de variedades plantadas por campo no caso das melhoradas.

A ocorrência do grupo 1 no Brasil em campos de Petrolina havia sido preliminarmente reportada (Quezado-Soares et al., 1997). Se a variação intra-específica encontrada nos quatro grupos/espécies está ou não refletindo a variação global do grupo/espécie não pode ser afirmado com certeza. Porém, se essa hipótese não for verdadeira e as espécies apresentarem o mesmo grau de variação intra-específica, é razoável associar o baixo polimorfismo encontrado nos grupos 2 e 4 (“X. gardneri”) a um evento de introdução mais recente. De fato, isolados desses dois grupos em geral foram obtidos de híbridos importados. A substituição de variedades PA em detrimento 
de híbridos importados aumentou nos últimos anos (45\% em 1998 para o estimado de $80 \%$ em 1999), notadamente na nova fronteira agrícola do Brasil-Central (Giordano et al., 2000). No entanto, algumas populações atípicas foram encontradas, como a de IPA5/Petrolina-1996, com indivíduos quase todos monomórficos entre si pertencentes ao grupo 2. A falta de informação sobre o fluxo de germoplasma entre localidades, bem como da existência e tipos de variedade de outros campos adjacentes aos coletados, principalmente no Nordeste, impede que se trace precisamente a origem e direção da distribuição do patógeno entre as populações.

O grupo 3 (“X. vesicatoria", grupo "B”), por sua vez, também apresentou baixo polimorfismo mas esteve associado tanto à variedade PA nacional 401-8 como a híbridos importados. Além disso, a presença do grupo no país já havia sido relatada (Bouzar et al., 1994b). Aparentemente, a importância desse grupo foi reduzida nas lavouras de tomate rasteiro no país, uma vez que predominava em Itapaci em 1995 mas não foi mais detectada em coletas posteriores a 1997. Fatores ligados à adaptabilidade e/ou a competitividade entre os diversos grupos podem estar ocorrendo, como já demonstrado na Flórida (EUA) entre os grupos “A” e "D” (Jones et al., 1998a).

Ainda em relação ao grau de polimorfismo dos quatro grupos, vale observar que o número de isolados amostrados por campo poderia ter sido reduzido, pois populações puderam ser caracterizadas como polimórficas com cerca de 20 isolados, a exemplo de Petrolina-1996. A análise de PFGE, conforme discutido por outros autores (Cooksey \& Graham, 1989), mostrou-se uma ferramenta apropriada para estudos de estrutura de populações de bactérias fitopatogênicas em nível subespecífico e também para estudos epidemiológicos. Interessante será acompanhar a dinâmica populacional dos grupos reportados aqui pela primeira vez ao longo do tempo. 


\section{OCORRÊNCIA DE RAÇAS DE Xanthomonas SPP. EM PLANTIOS COMERCIAIS DO BRASIL-CENTRAL E NORDESTE}

\section{RESUMO}

A grande diversidade genética dos agentes causadores da mancha-bacteriana tem dificultado o desenvolvimento de variedades de pimentão e tomateiro com resistência durável. Setenta e dois isolados de Xanthomonas spp. provenientes de campos comerciais de tomate para processamento industrial dos estados de Goiás, Minas Gerais, Pernambuco e Bahia foram classificados em raças com base nas reações de genótipos diferenciais de tomateiro (Walter, Hawaii 7998 e NIL 216) e de Capsicum (ECW [Early Calwonder], ECW-10R, ECW-20R, ECW-30R e PI235047). As plantas foram inoculadas no estádio de três a cinco folhas verdadeiras, por infiltração de suspensão bacteriana $\left(5 \times 10^{8} \mathrm{UFC} / \mathrm{mL}\right)$ na superfície adaxial da folha. Em seguida, foram mantidas em câmara de crescimento em fotoperíodo de 12h/12h (luz/escuro) a $28^{\circ} \mathrm{C}$. A reação de hipersensibilidade foi observada até 36 horas após a inoculação, dependendo do genótipo da hospedeira. Foram identificadas as raças T1P2, T1P8 e T3 em $X$. axonopodis pv. vesicatoria; a raça $\mathrm{T} 2 \mathrm{em} X$. vesicatoria; e as raças T2P7 e T2P8 em ' $X$. gardneri'. A presença dos genes $a v r R x v$ e $a v r X v 3$ nos isolados que causaram reação de hipersensibilidade em 'Hawaii 7998'(raça T2) e 'NIL 216' (raça T3), respectivamente, foi confirmada por reação em cadeia da polimerase (PCR) usando iniciadores específicos. Este é o primeiro relato da ocorrência no Brasil das raças T3, T1P8, T2P7 e T2P8. 


\section{Occurrence of races of Xanthomonas spp. in commercial fields of processing tomatoes in Central and Northeast Brazil}

\section{SUMMARY}

The great genetic diversity of the causal agents of bacterial spot is the main problem to the development of tomato and pepper varieties with durable resistance. Seventy two strains of Xanthomonas spp. collected from commercial fields of processing tomatoes in the states of Goiás, Minas Gerais, Pernambuco and Bahia were classified into races according to their reactions elicited on differential genotypes of tomato (Walter, Hawaii 7998 and NIL 216) and Capsicum (ECW [Early Calwonder], ECW-10R, ECW-20R, ECW-30R and PI 235047). Bacterial suspensions $\left(5 \times 10^{8}\right.$ $\mathrm{UFC} / \mathrm{mL}$ ) were infiltrated in the adaxial leaf face of the plants at the three to five trueleaf stage. The plants were then kept in a growth chamber at $28^{\circ} \mathrm{C}$ under a $12-\mathrm{h}$ light/dark photoperiod. The response reactions were observed up to 36 hours after inoculation, depending on the genotype. Races T1P2, T1P8 and T3 were identified in $X$. axonopodis pv. vesicatoria; race $\mathrm{T} 2$ in $X$. vesicatoria; and races $\mathrm{T} 2 \mathrm{P} 7$ e $\mathrm{T} 2 \mathrm{P} 8$ in ' $X$. gardneri'. The presence of genes avrRxv and avrXv3 was confirmed by polymerase chain reaction (PCR) with specific primers in strains that produced hypersensitive reaction on 'Hawaii 7998' (races T2) and 'NIL 216' (race T3), respectively. This is the first report of races T3, T1P8, T2P7 and T2P8 in Brazil.

\subsection{INTRODUÇÃO}

A resistência varietal é uma importante ferramenta para o controle de doenças de plantas, notadamente as causadas por bactérias fitopatogênicas onde o controle químico é muitas vezes ineficaz (Lopes \& Quezado-Soares, 1997). A eficiência e durabilidade da resistência depende, entre outros fatores, da variabilidade genética do patógeno. Variações em patogenicidade expressas em termos de raças fisiológicas 
ocorrem em diversos patógenos, evoluindo freqüentemente nas populações em resposta à introdução de genes de resistência dominantes de efeito qualitativo, os chamados genes “ $R$ ” (Crute \& Pink, 1996). Raças virulentas compatíveis passam então a predominar, ocasionando a "quebra" da resistência da cultivar (Fry, 1982).

No complexo etiológico da mancha-bacteriana das solanáceas causado por espécies de Xanthomonas (Jones et al., 2000), já foram identificadas três raças em relação ao gênero Lycopersicon (raças T) (Wang et al., 1990; Jones et al., 1995) e onze em relação a Capsicum (raças P) (Kousik \& Ritchie, 1995; Ritchie et al., 1998; Sahin \& Miller, 1995; Sahin \& Miller, 1997) (Tabelas 1 e 2). Diferentes combinações entre as raças $\mathrm{T}$ e $\mathrm{P}$ também foram observadas em isolados que infectam as duas hospedeiras (Bouzar et al., 1994b; Jones et al., 1995; Jones et al., 1998a).

Tabela 1. Reações de genótipos de tomate (Lycopersicon spp.) às raças de Xanthomonas spp. causadoras de mancha-bacteriana.

\begin{tabular}{|c|c|c|c|}
\hline \multirow[t]{2}{*}{ Raças } & \multicolumn{3}{|c|}{ Genótipos diferenciais } \\
\hline & Walter & Hawaii 7998 & Hawaii $7981^{1}$ \\
\hline $\mathrm{T} 1$ & $\mathrm{~S}^{2}$ & $\mathrm{RH}^{2}$ & $\mathrm{~S}$ \\
\hline $\mathrm{T} 2$ & $\mathrm{~S}$ & $\mathrm{~S}$ & $\mathrm{~S}$ \\
\hline $\mathrm{T} 3$ & $\mathrm{~S}$ & $\mathrm{~S}$ & $\mathrm{RH}$ \\
\hline
\end{tabular}

1. Lycopersicon pimpinellifolium PI 128216 e PI 126932 mostram a mesma reação.

2 . S: suscetibilidade; RH: reação de hipersensibilidade. Fontes: Bouzar et al., 1994b; Jones et a., 1998b. 
Tabela 2. Reações de genótipos de Capsicum spp. às raças de Xanthomonas spp. causadoras de mancha-bacteriana.

\begin{tabular}{cccccc}
\hline Raças & \multicolumn{5}{c}{ Genótipos diferenciais $^{1}$} \\
& ECW & ECW-10R & ECW-20R & ECW-30R & PI 235047 \\
\hline P0 & $\mathrm{S}^{2}$ & $\mathrm{RH}^{2}$ & $\mathrm{RH}$ & $\mathrm{RH}$ & $\mathrm{RH}$ \\
P1 & $\mathrm{S}$ & $\mathrm{S}$ & $\mathrm{RH}$ & $\mathrm{RH}$ & $\mathrm{RH}$ \\
P2 & $\mathrm{S}$ & $\mathrm{RH}$ & $\mathrm{RH}$ & $\mathrm{S}$ & $\mathrm{S}$ \\
P3 & $\mathrm{S}$ & $\mathrm{S}$ & $\mathrm{RH}$ & $\mathrm{S}$ & $\mathrm{RH}$ \\
P4 & $\mathrm{S}$ & $\mathrm{S}$ & $\mathrm{S}$ & $\mathrm{RH}$ & $\mathrm{RH}$ \\
P5 & $\mathrm{S}$ & $\mathrm{RH}$ & $\mathrm{S}$ & $\mathrm{S}$ & $\mathrm{S}$ \\
P6 & $\mathrm{S}$ & $\mathrm{S}$ & $\mathrm{S}$ & $\mathrm{S}$ & $\mathrm{RH}$ \\
P7 & $\mathrm{S}$ & $\mathrm{S}$ & $\mathrm{RH}$ & $\mathrm{RH}$ & $\mathrm{S}$ \\
P8 & $\mathrm{S}$ & $\mathrm{S}$ & $\mathrm{RH}$ & $\mathrm{S}$ & $\mathrm{S}$ \\
P9 & $\mathrm{S}$ & $\mathrm{RH}$ & $\mathrm{S}$ & $\mathrm{S}$ & $\mathrm{S}$ \\
P10 & $\mathrm{S}$ & $\mathrm{S}$ & $\mathrm{S}$ & $\mathrm{S}$ & $\mathrm{S}$ \\
\hline
\end{tabular}

1. Capsicum annuum L. cvs. Early Calwonder, com genes de resistência $B s 1, B s 2$ e $B s 3$, respectivamente em ECW10R, ECW20R e ECW 30R; PI 235047: C. pubescens R. \& P. (gene de resistência ainda não identificado).

2. S: suscetibilidade; RH: reação de hipersensibilidade. Fonte: Ritchie et al., 1998.

As raças são definidas com base em reações de um grupo definido de genótipos das hospedeiras (Leach \& White, 1996). Algumas das interações observadas entre as espécies de Xanthomonas associadas à mancha-bacteriana e as hospedeiras Lycopersicon e Capsicum seguem o modelo gene-a-gene proposto por Flor na década de 40 (AstuaMonge et al., 2000a; Romero et al, 2002). No modelo, genes de avirulência (avr) do patógeno interagem com genes de resistência da hospedeira, resultando em uma reação de incompatibilidade, ou seja, de resistência (Leach \& White, 1996). Essa resposta da hospedeira é, na verdade, uma morte localizada de suas células no ponto de penetração do patógeno, limitando a disseminação do mesmo (Beynon, 1997). A fácil identificação da resposta de incompatibilidade em bactérias foi possível com a técnica desenvolvida por Klement em 1963, citado por Goodman \& Novacky (1994), onde células bacterianas 
em suspensão concentrada (superior a $10^{6} \mathrm{UFC} / \mathrm{mL}$ ) são infiltradas no tecido das folhas da hospedeira e os sintomas observados cerca de 12 a 24 horas após.

Como exemplos que seguem o modelo no patossistema em questão cita-se: a) a interação entre os genes $B s 1, B s 2$ e $B s 3$, presentes em genótipos de Capsicum, e os respectivos genes $a v r B s 1, a v r B s 2$ e $a v r B s 3$ (Stall, 1997); b) entre o gene $X v 3$ encontrado nos genótipos Hawaii 7981 (L. esculentum Mill.), PI 128216 e PI 126932 (ambos L.

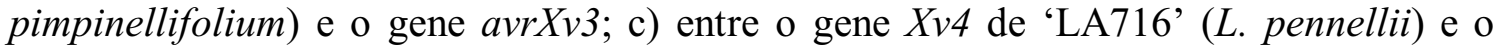
gene $a v r X v 4$, ambos presentes na raça T3 (Astua-Monge et al., 2000a; Astua-Monge et al., 2000b) e d) avrBs4 (=avrBsP sensu Canteros et al., 1991 e avrBs3-2 sensu Bonas et al., 1993), que induz incompatibilidade em acessos de tomate portando o gene Bs4 (Ballvora et al., 2001).

Existem ainda algumas interações cujos genes ainda não foram identificados (gene de avirulência e/ou de resistência), e outras que envolvem mais de um gene de resistência. No primeiro caso tem-se o gene $\operatorname{avr} B s T$, que induz incompatibilidade em Capsicum (Minsavage et al., 1990) e os genes envolvidos na interação entre $C$. pubescens e certas raças P (Sahin \& Miller, 1998). No segundo caso, cita-se a interação entre o gene avrRxv da raça T1 (Whalen et al., 1988; Whalen et al., 1993) com pelo menos três genes de resistência não-dominantes ( $r x 1, r \times 2$ e $r \times 3)$ do genótipo 'Hawaii 7998' (Wang et al., 1994; Yu et al., 1995) que resulta em reação de hipersensibilidade (Jones \& Scott, 1986). Por outro lado, para a raça T2 não existem fontes conhecidas de resistência qualitativa (Scott et al., 1997; Wang et al., 1990).

Isolados da raça T1 têm sido agrupados no grupo fenotípico "A" (= $X$. axonopodis pv. vesicatoria sensu Vauterin et al., 1995); da raça T2 no grupo "B" (= $X$. vesicatoria sensu Vauterin et al., 1995) ou no grupo " $D$ " (= 'X. gardneri' de acordo com Jones et al., 2000) e da raça T3, no grupo “C” (= subgrupo de X. axonopodis pv. vesicatoria conforme Jones et al., 2000). No relato de Bouzar et al. (1994b), isolados brasileiros foram identificados como raças T1P0, T1P2, T2, T2P1 e T2P3.

Este trabalho teve como objetivo determinar as raças de Xanthomonas spp. associadas à mancha-bacteriana em relação a genótipos diferenciais de Lycopersicon 
esculentum Mill. e de Capsicum spp. presentes em amostras de isolados provenientes de campos de tomateiro destinados ao processamento industrial no Brasil.

\subsection{MATERIAL E MÉTODOS}

\subsubsection{Obtenção, manutenção e identificação dos isolados}

Foram analisados 72 isolados de Xanthomonas spp. coletados a partir de 1995 em 31 campos comerciais de tomate para processamento industrial localizados nos estados de Goiás, Minas Gerais, Pernambuco e Bahia (Tabela 3). Desses, 57 isolados foram previamente classificados em $X$. axonopodis pv. vesicatoria, $X$. vesicatoria ou ' $X$. gardneri', conforme descrito no capítulo 4. Os 15 isolados restantes foram os pertencentes ao grupo PFGE 2, tentativamente classificados como uma subespécie de $X$. axonopodis pv. vesicatoria (capítulo 4).

Tabela 3. Local, ano e número de isolados coletados em campos comerciais de tomate para processamento industrial no Brasil.

\begin{tabular}{|c|c|c|c|c|}
\hline Estado e município & $\begin{array}{l}\text { Ano da } \\
\text { coleta }\end{array}$ & Campo & Variedade & $\begin{array}{l}\text { Número de } \\
\text { isolados }\end{array}$ \\
\hline \multicolumn{5}{|l|}{ Brasil-Central } \\
\hline \multirow[t]{4}{*}{ Itapaci-GO } & 1995 & 1 & Mistura de híbridos & 3 \\
\hline & & 2 & Mistura de híbridos & 1 \\
\hline & & 3 & Hypee19280 & 2 \\
\hline & & 4 & $401-8$ & 3 \\
\hline \multirow[t]{3}{*}{ Itapaci-GO } & 1997 & 5 & $401-8$ & 1 \\
\hline & & 6 & Andino & 1 \\
\hline & & 7 & Topmec & 3 \\
\hline \multirow[t]{3}{*}{ Rio Verde-GO } & 1997 & 1 & Mistura de híbridos das séries & 1 \\
\hline & & & $\begin{array}{c}\text { APTX e Heinz, Agroceres } 7022 \text { e } \\
\text { Andino }\end{array}$ & \\
\hline & & 2 & Santa Adelia & 1 \\
\hline \multirow{3}{*}{ Morrinhos-GO } & 1998 & 1 & Hypeel 108, Hypeel 45 & 3 \\
\hline & & 2 & Hypeel 45, Rio Grande & 3 \\
\hline & & 3 & Petomec & 2 \\
\hline Morrinhos-GO & 2000 & 4 & RPT 1570, Hypeel 108, Petoseed & 1 \\
\hline
\end{tabular}




\begin{tabular}{lcccc}
\hline Estado e município & $\begin{array}{c}\text { Ano da } \\
\text { coleta }\end{array}$ & Campo & Variedade & $\begin{array}{c}\text { Número de } \\
\text { isolados }\end{array}$ \\
\hline Patos de Minas-MG & 1998 & 1 & Viradoro, Ragu 9414, Heinz 9498 & 1 \\
Nordeste & & & & \\
Abaré-BA & 1998 & 1 & IPA-5 & 4 \\
& & 2 & IPA-5 & 5 \\
& & 3 & IPA-5 & 2 \\
Juazeiro-BA & 4 & IPA-5 & 3 \\
Orocó-PE & 1998 & 1 & IPA-5 & 2 \\
& 1998 & 1 & U-570 & 1 \\
Petrolina-PE & & 2 & U-570 & 1 \\
& 1996 & 1 & IPA-5 & 4 \\
& & 2 & IPA-5 & 3 \\
Petrolina-PE & 3 & IPA-5 & 5 \\
& & 4 & IPA-5 & 2 \\
& 1998 & 5 & IPA-5 & 1 \\
& & 6 & IPA-5 & 2 \\
& & 7 & IPA-5 & 1 \\
& & 8 & IPA-5 & 2 \\
\hline
\end{tabular}

\subsubsection{Identificação das raças}

Foram utilizados os genótipos diferenciais de tomateiro Walter, Hawaii 7998 e NIL 216 (linha quase isogênica ao genótipo suscetível Fla. 7060 com gene de resistência derivado do genótipo PI 128216 [Astua-Monge et al., 2000a]), e de Capsicum annuum ECW (Early Calwonder), ECW-10R, ECW-20R, ECW-30R e C. pubescens PI 235047. As sementes foram obtidas dos bancos de germoplasma de tomateiro e de pimentas/pimentão do Centro Nacional de Pesquisa de Hortaliças da Empresa Brasileira de Pesquisa Agropecuária (Embrapa Hortaliças), Brasília. O semeio foi em bandejas de polistereno de 128 células preenchidas com substrato agrícola Plantmax ${ }^{\circledR}$ (Eucatex). O transplantio para sacos de plástico preto com capacidade de 1,5 L, preenchidos com solo esterilizado, foi feito quando as plantas apresentavam duas a três folhas verdadeiras.

Para a obtenção das culturas bacterianas em meio líquido caldo nutriente, procedeu-se como descrito no item 3.2.2, utilizando-se um volume de $15 \mathrm{~mL}$ de meio em tubo de plástico com fundo cônico com capacidade para $50 \mathrm{~mL}$. As suspensões obtidas após o período de incubação foram então centrifugadas em centrífuga Beckman 
GS-6 (Palo Alto, CA, EUA), rotor GH3.8, a $2.800 \times g$ por 20 minutos e o sedimentado resultante re-suspendido em água destilada a uma concentração de $5 \times 10^{8} \mathrm{UFC} / \mathrm{mL}$ segundo leitura em espectrofotômetro $\left(\mathrm{A}_{600}=0,3\right)$. As plantas foram inoculadas no estádio de seis a sete folhas verdadeiras (cerca de 7 a 8 semanas após o semeio de pimentão e de tomate, respectivamente), através da infiltração de suspensão bacteriana $\left(5 \times 10^{8} \mathrm{UFC} / \mathrm{mL}\right)$ na superficie adaxial da folha. Durante esse período, as plantas foram mantidas em câmara de crescimento em fotoperíodo de $12 \mathrm{~h} / 12 \mathrm{~h}$ (luz/escuro) a $28^{\circ} \mathrm{C}$. A reação de hipersensibilidade foi caracterizada pela necrose dos tecidos em até 36 horas após a inoculação, dependendo do genótipo da hospedeira (6-12 horas para ECW-10R; 12-24 horas para ECW-20R; 24-36 horas para ECW-30R e aproximadamente de 24 horas para PI 235047, 'Hawaii 7998' e 'NIL 216' [Jones et al., 1995; Sahin \& Miller, 1998; Stall, 1997]).

\subsubsection{Presença dos genes avrRxv e avrXv3}

A presença dos genes $a v r R x v$ e $a v r X v 3$ foi verificada pela reação em cadeia da polimerase (PCR) em todos os isolados que provocaram resposta de hipersensibilidade nos genótipos diferenciais Hawaii 7998 e NIL 216, respectivamente. Os isolados de ' $X$. gardneri' foram previamente analisados quanto à presença do gene avrRxv (capítulo 3). DNA genômico total foi isolado pelo método de purificação CTAB conforme item 3.2.3. Para a amplificação do fragmento de 680-pb contendo o gene avrRxv, utilizou-se os iniciadores RST27 (5'-AGTCGCGCGGACATTTAGCCCC GCC) e RST28 (5'CGTCGATGGTGCGCCTGGAATGCGC) e o programa de amplificação descrito no referido item. Já para a amplificação do fragmento de 654-pb contendo o gene avrXv3, a reação da PCR foi composta por $100 \mathrm{ng}$ do DNA molde, $5 \mu \mathrm{L}$ de tampão de amplificação (Promega Life Science, Madison, WI, EUA), 1,5 mM de $\mathrm{MgCl}_{2}, 1,25 \mathrm{U}$ de Taq DNA polimerase (Promega), $100 \mu \mathrm{M}$ de cada deoxinucleosídeo trifosfato (dNTPs) e 1,0 $\mu \mathrm{M}$ dos iniciadores RST88 (5'-CCGCTCGAGATGACAAGT AGTATCAATC) e RST89 (5'-CCGCTCGAGCTACTTAACGAGATTTGTTAC) (Astua-Monge et al., 2000a), em um volume final de $50 \mu \mathrm{L}$. Para esse par de iniciadores, empregou-se um 
ciclo inicial de desnaturação a $95^{\circ} \mathrm{C}$ por 30 segundos, hibridização a $48^{\circ} \mathrm{C}$ por 30 segundos e extensão a $72^{\circ} \mathrm{C}$ por 1 minuto, seguido de 30 ciclos onde a temperatura de hibridização foi elevada a $56^{\circ} \mathrm{C}$ e as demais mantidas. $\mathrm{O}$ último passo de extensão foi de 5 minutos a $72^{\circ} \mathrm{C}$. Para ambos os genes, os produtos da PCR foram detectados por eletroforese em gel de $1 \%$ de agarose em tampão de corrida TBE $0,5 \mathrm{X}$ a $5 \mathrm{~V} / \mathrm{cm}$ de gel. Os géis foram corados com brometo de etídio $(0,5 \mu \mathrm{g} / \mathrm{mL})$ e fotodocumentados com aparelho Image Master ${ }^{\circledR}$ VDS (Pharmacia Biotech, San Francisco, EUA).

\subsection{RESULTADOS}

Respostas de hipersensibilidade foram observadas nos genótipos 'Hawaii 7998' e 'NIL 216', bem como nas linhas quase isogênicas de pimentão ECW portadoras dos genes de resistência $B s 1, B s 2$ e $B s 3$ (Figura 1). A partir de 48 horas foi possível visualizar o colapso dos tecidos (reação de suscetibilidade) nas variedades suscetíveis Walter e Early Calwonder não-portadoras de gene " $R$ ", bem como nas demais variedades desafiadas com isolados compatíveis.

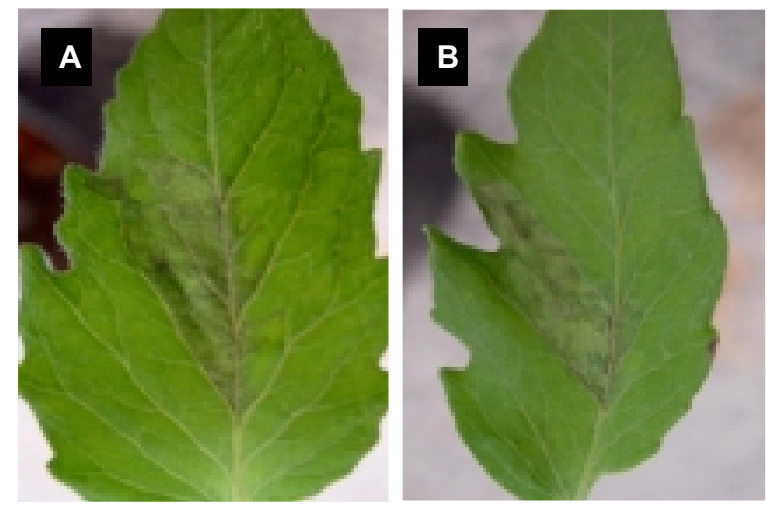

Figura 1 - Reação de hipersensibilidade em 'Hawaii 7998' (A) e 'NIL 216’ (B).

Em relação à localidade, constatou-se a ocorrência das raças T1P8 e T3 apenas na região Nordeste, ao passo que as raças T2, T2P7 e T2P8 foram detectadas apenas no Brasil-Central (Tabela 4). A raça T1P2 ocorreu em ambas regiões. Nos quatro campos de Abaré e em um campo em Petrolina, em 1996, foi possível observar a ocorrência concomitante de duas raças distintas (campos 1, 3 e 4 de Abaré e 3 de Petrolina; campo 
2 de Abaré). Nos demais campos, apenas uma raça foi detectada. Os prováveis genes de avirulência presentes nos isolados analisados foram compilados de acordo com as reações de resposta de cada hospedeira diferencial (Tabela 5).

Tabela 4. Raças detectadas em campos comerciais de tomate para processamento industrial em municípios do Brasil-Central e Nordeste, no período de 1995 a 2000.

\begin{tabular}{|c|c|c|c|c|}
\hline Ano & Local & Total de isolados & Campo & Raças $^{1}$ \\
\hline & Brasil-Central & & & \\
\hline \multirow[t]{2}{*}{1995} & Itapaci-GO & 9 & 1 & T1P2 (2) \\
\hline & & & $1,2,3,4$ & $\mathrm{~T} 2(7)$ \\
\hline \multirow[t]{3}{*}{1997} & Itapaci-GO & 5 & 1 e 3 & T2P7 (2) \\
\hline & & & 2 & T2P8 (1) \\
\hline & & & 3 & $\mathrm{~T} 2(2)$ \\
\hline 1997 & Rio Verde-GO & 3 & 1 e 2 & T2P8 (2) \\
\hline \multirow[t]{3}{*}{1998} & Morrinhos-GO & 8 & 1,2 e 3 & $\mathrm{~T} 1 \mathrm{P} 2(4)$ \\
\hline & & & 2 & T2P7 (1) \\
\hline & & & 1 e 3 & T2P8 (3) \\
\hline 1998 & Patos de Minas-MG & 1 & 1 & $\mathrm{~T} 2 \mathrm{P} 7(1)$ \\
\hline \multirow[t]{2}{*}{2000} & Morrinhos-GO & 1 & 4 & T2P8 (1) \\
\hline & Nordeste & & & \\
\hline \multirow[t]{2}{*}{1996} & Petrolina-PE & 18 & $1,2,3$ e 4 & T1P2 (17) \\
\hline & & & 3 & T1P8 (1) \\
\hline \multirow[t]{3}{*}{1998} & Abaré-BA & 14 & $1,2,3$ e 4 & T1P2 (10) \\
\hline & & & 1,3 e 4 & T1P8 (3) \\
\hline & & & 2 & $\mathrm{~T} 3(1)$ \\
\hline 1998 & Juazeiro-BA & 2 & 1 & $\mathrm{~T} 3(2)$ \\
\hline 1998 & Petrolina-PE & 10 & $5,6,7,8,9$ e 10 & T3 (10) \\
\hline 1998 & Orocó-PE & 2 & 1 e 2 & $\mathrm{~T} 3(2)$ \\
\hline
\end{tabular}

1. Números entre parênteses referem-se ao número de isolados. 
Tabela 5. Reações de hospedeiras diferenciais de Lycopersicon e Capsicum e prováveis genes de avirulência presentes nos isolados analisados.

\begin{tabular}{|c|c|c|c|c|c|c|c|c|c|}
\hline & \multicolumn{3}{|c|}{ Genótipos de tomateiro } & \multicolumn{5}{|c|}{ Genótipos de Capsicum spp. } & \multirow[t]{2}{*}{$\begin{array}{l}\text { Prováveis } \\
\text { genes } a v r\end{array}$} \\
\hline & Walter & H7998 & 216 & ECW & $10 \mathrm{R}$ & $20 \mathrm{R}$ & $30 \mathrm{R}$ & PI1235047 & \\
\hline T1P2 & $\mathrm{S}$ & $\mathrm{H}$ & $\mathrm{S}$ & $\mathrm{S}$ & $\mathrm{H}$ & $\mathrm{H}$ & $\mathrm{S}$ & $\mathrm{S}$ & $\begin{array}{c}\text { avrRxv, } \\
\text { avrBs } 1, \\
\text { avrBs } 2\end{array}$ \\
\hline T1P8 & $\mathrm{S}$ & $\mathrm{H}$ & $\mathrm{S}$ & $\mathrm{S}$ & $\mathrm{S}$ & $\mathrm{H}$ & $\mathrm{S}$ & $\mathrm{S}$ & $a v r B s 2$ \\
\hline $\mathrm{T} 2$ & $\mathrm{~S}$ & $\mathrm{~S}$ & $\mathrm{~S}$ & $\mathrm{H}$ & $\mathrm{H}$ & $\mathrm{H}$ & $\mathrm{H}$ & $\mathrm{H}$ & $a v r B s T$ \\
\hline $\mathrm{T} 2 \mathrm{P} 7$ & $\mathrm{~S}$ & $\mathrm{~S}$ & $\mathrm{~S}$ & $\mathrm{~S}$ & $\mathrm{~S}$ & $\mathrm{H}$ & $\mathrm{H}$ & $\mathrm{S}$ & $\begin{array}{l}\text { avrBs } 2, \\
\text { avrBs3 }\end{array}$ \\
\hline $\mathrm{T} 2 \mathrm{P} 8$ & $\mathrm{~S}$ & $\mathrm{~S}$ & $\mathrm{~S}$ & $\mathrm{~S}$ & $\mathrm{~S}$ & $\mathrm{H}$ & $\mathrm{S}$ & $\mathrm{S}$ & $\begin{array}{l}a v r B s 2 \\
a v B s T\end{array}$ \\
\hline $\mathrm{T} 3$ & $\mathrm{~S}$ & $\mathrm{~S}$ & $\mathrm{H}$ & $\mathrm{H}$ & $\mathrm{H}$ & $\mathrm{H}$ & $\mathrm{H}$ & $\mathrm{H}$ & $\begin{array}{c}a v r X v 3, \\
a v r X v 4\end{array}$ \\
\hline
\end{tabular}

1. Genes de avirulência descritos na literatura.

A amplificação do fragmento de 680-pb contendo o gene avrRxv ocorreu nos 38 isolados que provocaram resposta de hipersensibilidade no genótipo 'Hawaii 7998' (Figura 2). DNA de isolados representantes das raças T2, T2P7/8 e T3 foram utilizados com os mesmos iniciadores (RST27 e RST28) mas nenhum produto foi amplificado. Já o fragmento de 654-pb contendo o gene avrXv3 foi amplificado apenas nos 15 isolados que causaram reação de hipersensibilidade em 'NIL 216' (Figura 2). 


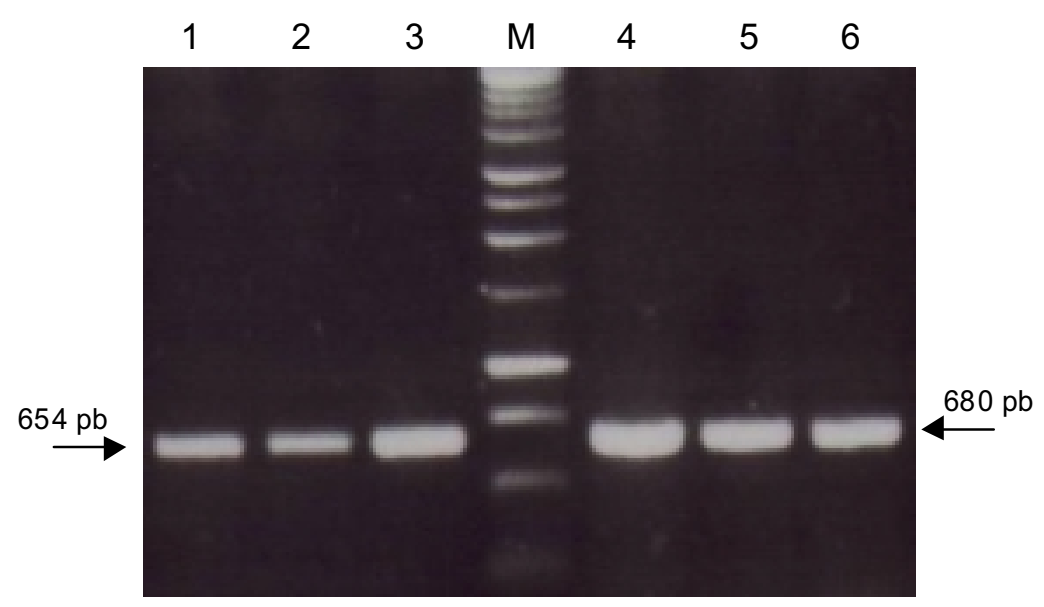

Figura 2 - Fragmentos de DNA genômico de Xanthomonas spp. de 680 pb, contendo o gene avrRxv (à direita do marcador M), e de $654 \mathrm{pb}$, contendo o gene avrXv3 (à esquerda do marcador M). Poços 1 a 3, isolados CNPH215 (raça T1P2), CNPH513 (T1P8) e CNPH517 (T1P2); Poço M, marcador molecular 1kb (Promega Corporation, Mandison, WI, USA); poços 4 a 6, isolados raça T3, CNPH429, CNPH440 e CNPH520.

\subsection{DISCUSSÃO}

O presente trabalho relata a ocorrência, pela primeira vez, de algumas raças de Xanthomonas spp. no Brasil. Maior destaque deve ser dado à detecção da raça T3 no Nordeste, uma vez que a ocorrência dessa raça havia sido descrita somente no estado da Flórida nos EUA, Tailândia e México (Bouzar et al., 1996; Jones et al., 1998a). Assim, para essa região onde a gama de variedades plantadas é bem mais restrita comparativamente ao Brasil-Central, a utilização de variedades contendo o gene de resistência $X v 3$ poderia resultar em um controle da doença (Astua-Monge et al., 2000a). Alternativamente, o gene $X v 4$, de L. pennelli poderia ser utilizado, caso fosse constatado que os isolados T3 no Brasil, a exemplo dos isolados da Flórida, também portam o gene avrRv4 (Astua-Monge et al, 2000b). A estabilidade da resistência conferida por esses 
genes, no entanto, ainda está por ser avaliada. Outro fator interessante em relação a essa raça é que ela tem se mostrado mais agressiva do que a raça $\mathrm{T} 1$, e hoje predomina no estado da Flórida (Jones et al., 1998b).

Em relação às espécies/grupos $\mathrm{PFGE}$, isolados de $X$. axonopodis pv. vesicatoria (grupo PFGE 1 = "A" sensu Jones et al., 2000) foram classificados em raças T1P2 e T1P8; de $X$. vesicatoria (PFGE 2 = "B") em raça T2; de 'X. gardneri' (PFGE 4 = "D") em raças T2P7 e T2P8 e os 15 isolados pertencentes ao grupo PFGE 3 (capítulo 4), em raça T3. A distribuição das raças de acordo com as espécies apontadas neste estudo concorda com a existência de uma correlação entre raças $\mathrm{T}$ e grupos fenotípicos/espécies (Bouzar et al., 1994b; Bouzar et al., 1996; Bouzar et al., 1999; Louws et al., 1995). Dessa maneira, isolados T1 apresentam certas características fenotípicas e genotípicas que os classificam como pertencentes à espécie $X$. axonopodis pv. vesicatoria (= grupo fenotípico “A”, sensu Stall et al., 1994; PFGE “A” sensu Jones et al., 2000); isolados T3 têm sido classificados como um subgrupo dentro dessa espécie (Jones et al., 2000); e isolados T2 estavam associados a X. vesicatoria (grupo "B" sensu Stall et al., 1994; PFGE "B" sensu Jones et al., 2000) (Bouzar et al., 1994b).

Já para o gênero Capsicum, assim como relatado por Bouzar et al. (1999) e Louws et al. (1995), que utilizaram perfis gerados por rep-PCR para caracterizar isolados de Xanthomonas associadas à mancha-bacteriana, perfis de PFGE não se correlacionaram com as características de patogenicidade. Esse resultado não é surpreendente, uma vez que essas características estão relacionadas com a presença de certos genes de avirulência na bactéria, em geral localizados em plasmídeos, não detectados pela técnica e passíveis de transferência lateral.

Como também analisado por Sahin (1997), a raça T1 parece ter maior habilidade em adaptar-se às plantas de Capsicum, uma vez que também é patógeno dessa hospedeira. Essa adaptação talvez possa ter ocorrido pela perda do gene avrBsT que resulta em hipersensibilidade em genótipos de Capsicum (Minsavage et al., 1990). No entanto, os fatores evolutivos envolvidos não são conhecidos. A raça T2, por sua vez, era considerada mais especializada em Lycopersicon (Bouzar et al., 1994b; Sahin, 
1997), porém, em 'X. gardneri', tem se mostrado patogênica às duas hospedeiras (ver também capítulo 1). Já a raça T3 ainda é aparentemente mais especializada ao tomateiro.

A presença do gene avrBsT nas raças T2 de $X$. vesicatoria e T3 pode ser confirmada através de detecção por PCR, já que sua seqüência é conhecida (Ciesiolka et al., 1999), a exemplo do que foi feito neste trabalho para os genes $a v r R x v$ e $a v r X v 3$. Para isso, no entanto, seria necessário o desenvolvimento de iniciadores específicos. Da mesma forma, seria interessante confirmar a presença do gene avrBs2. Sua presença foi inferida com base nos testes de hipersensibilidade aqui apresentados em todos os isolados que também foram patogênicos a Capsicum (Tabela 5). De fato, uma alta freqüência desse gene tem sido observada, inclusive de seus homólogos em Xanthomonas de outras hospedeiras (Kearney \& Staskawicz, 1990). Um papel importante na patogenicidade tem sido apontado como a causa dessa ampla distribuição (Kearney \& Staskawicz, 1990). Em virtude disso, a possibilidade do uso do gene de resistência $B s 2$ do pimentão em plantas transgênicas de tomate está sendo analisada (Tai et al., 1999).

Em relação a ' $X$. gardneri', por ser de ocorrência pouco freqüente em nível mundial, assim como a raça T3, apenas o isolado tipo XG101 e isolados da Costa Rica haviam sido classificados quanto à raça, sendo agrupados, respectivamente, em T2P1 e P1 (Bouzar et al., 1994b; Bouzar et al., 1999). Os isolados de 'X. gardneri' do BrasilCentral, por sua vez, foram classificados em raças distintas (T2P7 ou T2P8). No entanto, convém ressaltar que, com a inclusão do genótipo de C. pubescens PI 235047, raças anteriormente classificadas como P1 e P3 podem passar a ser designadas P7 e P8, respectivamente, de acordo com a reação de resposta desse genótipo (Ritchie et al., 1998; Sahin \& Miller, 1998).

O número de isolados analisados por campo em cada município foi baixo para que se viabilizasse uma análise apropriada do grau de diversidade de raças por campo. Porém, vale notar que, dos 31 campos avaliados, em apenas três campos em Abaré e um em Petrolina, foi possível detectar duas raças distintas em relação a Capsicum (T1P2 e T1P8). A conversão da raça P2 em raça P8 (ex-P3) poderia ser possível no próprio campo através da perda do gene avrBsl, localizado em plasmídeo (Minsavage et al., 
1990) ou inserção de um elemento genético móvel do tipo IS476 que inativa o gene avrBsl (Kearney \& Staskawicz, 1990). Mudanças de raças P têm sido observadas tanto in vitro, como em campo (Dahlbeck \& Stall, 1979; Pohoronezny et al., 1992). Kousik \& Ritchie (1996) registraram a conversão de populações de raças P1 (avrBs3) e P2 (avrBs 1), em populações P3, em dois campos, respectivamente, cultivados com pimentão resistentes ECW-30R (Bs3) e ECW-10R $(B s 1)$ no mesmo ciclo de cultivo. Para o primeiro caso, confirmou-se a perda do plasmídeo contendo o gene avrBs 3 e para o segundo, a mutação do gene $a v r B s 1$ pela inserção do elemento IS476. Outra hipótese para a presença das raças $\mathrm{P} 2$ e P8, mencionadas anteriormente no presente trabalho, seria a de que as duas raças foram introduzidas simultaneamente via sementes infectadas ou em eventos distintos.

Considerando que no Brasil, tanto as variedades de tomate para indústria como as de mesa e de pimentão não possuem nenhum gene de resistência caracterizado, sugere-se que a composição racial das populações aqui relatadas não seja um resultado de pressão de seleção exercida pela hospedeira e sim um resultado de eventos de introdução ocorridos ao acaso nos campos (efeito fundador) seguidos de adaptação ao ambiente.

O conhecimento da diversidade patogênica das populações bacterianas é de extrema importância para direcionar os programas de melhoramento e utilização de genes de resistência. A medida que o conhecimento sobre os genes de avirulência se acumula, torna-se possível avaliar as populações bacterianas locais e, desse modo, lançar mão daqueles genes de resistência que reconheçam os genes complementares de avirulência predominantes. O emprego da PCR pode vir a otimizar o processo de designação das raças, bem como viabilizar um monitoramento das populações quanto à presença dos genes de avirulência em um ciclo de plantio. 


\section{SENSIBILIDADE AO COBRE, ESTREPTOMICINA E OXITETRACICLINA EM Xanthomonas SPP. ASSOCIADAS À MANCHA-BACTERIANA DO TOMATEIRO RASTEIRO}

\section{RESUMO}

Apesar de amplamente empregados em lavouras de tomate para processamento industrial no Brasil, fungicidas cúpricos e antibióticos agrícolas nem sempre resultam em controle eficiente das bacterioses que afetam a cultura. $\mathrm{O}$ aparecimento de estirpes resistentes é uma das causas dessa baixa eficiência. Avaliou-se, in vitro, a sensibilidade ao cobre, estreptomicina e oxitetraciclina de 389 isolados de espécies de Xanthomonas que causam a mancha-bacteriana. Os isolados foram obtidos de plantas doentes em campos comerciais de tomateiro rasteiro nos estados de Goiás, Minas Gerais, Pernambuco e Bahia, nos anos de 1995 a 1998 e 2000. Gotas de $5 \mu$ de suspensões bacterianas foram depositadas em meio Ágar-Nutriente (AN) suplementados com sulfato de cobre $(50$ e $200 \mu \mathrm{g} / \mathrm{ml})$, sulfato de estreptomicina $(25 \mu \mathrm{g} / \mathrm{ml}$ e $200 \mu \mathrm{g} / \mathrm{ml})$ ou cloridrato de oxitetraciclina $(25 \mu \mathrm{g} / \mathrm{ml})$. Foi considerado resistente o isolado que apresentou crescimento confluente em três repetições. Nenhum isolado foi resistente à oxitetraciclina e ao cobre na concentração de $200 \mu \mathrm{g} / \mathrm{ml}$. No entanto, houve diferença entre isolados em sensibilidade ao cobre na concentração de $50 \mu \mathrm{g} / \mathrm{ml}$ e à estreptomicina nas duas concentrações. Foram resistentes à estreptomicina $(25 \mu \mathrm{g} / \mathrm{ml}) 98 \%$ dos isolados de 'X. gardneri', 38\% dos isolados de $X$. axonopodis pv. vesicatoria e apenas $2 \%$ dos isolados de $X$. vesicatoria. Para o cobre, a freqüência de isolados resistentes foi de $48 \%$, 4\% e 74\% para ' $X$. gardneri', $X$. axonopodis pv. vesicatoria e $X$. vesicatoria, respectivamente. 


\section{Sensitivity to streptomycin, oxitetracyclin and copper of xanthomonads associated to bacterial spot of processing tomatoes}

\section{SUMMARY}

Copper fungicides and antibiotics are frequently used to control bacterial diseases of processing tomatoes in Brazil. However, control failure is common and could be caused by the appearance of resistant strains. In vitro tests were carried out to evaluate the sensitivity to copper, streptomycin and oxitetracyclin of 389 Xanthomonas strains isolated from tomato plants with bacterial spot symptoms. The strains were obtained in commercial areas in the states of Goiás, Minas Gerais, Pernambuco and Bahia from 1995 to 1998 and 2000. Bacterial suspension droplets of $5 \mu$ l were deposited on Nutrient-Agar medium amended with copper sulfate (50 and $200 \mu \mathrm{g} / \mathrm{ml}$ ), streptomycin sulfate $(25 \mu \mathrm{g} / \mathrm{ml}$ e $200 \mu \mathrm{g} / \mathrm{ml})$ or oxitetracyclin hydrocloridrate (25 $\mu \mathrm{g} / \mathrm{ml})$. None of the strains were resistant either to oxitetracyclin or copper at $200 \mu \mathrm{g} / \mathrm{ml}$. However, strains differed in their sensitivity to $50 \mu \mathrm{g} / \mathrm{ml}$ copper and to streptomycin (both concentrations). Ninety eight percent of ' $X$. gardneri' strains, $38 \%$ of $X$. axonopodis pv. vesicatoria and only $2 \%$ of $X$. vesicatoria were resistant to streptomycin (25 $\mu \mathrm{g} / \mathrm{ml}$ ) whereas the frequency of resistant strains to copper was respectively, $48 \%$, $4 \%$ and $74 \%$.

\subsection{INTRODUÇÃO}

A mancha-bacteriana, causada por bactérias do gênero Xanthomonas (Dowson) (Jones et al., 2000), é uma das doenças mais importantes do tomateiro (Lycopersicon esculentum Mill.) rasteiro no Brasil, com ocorrências freqüentes em áreas irrigadas por aspersão ou pivô-central (Barbosa, 1997). As perdas devido a esta doença resultam da redução da produção em decorrência direta dos sintomas e do custo dos produtos químicos utilizados como estratégia de controle. 
Os principais princípios ativos que compõem os produtos registrados no Brasil para o controle da mancha-bacteriana são o cobre e os antibióticos estreptomicina e oxitetraciclina (Lopes \& Quezado-Soares, 1997). No entanto, vários relatos demonstram a baixa eficiência da estreptomicina e dos produtos cúpricos, tanto em lavouras de tomate (Goode \& Sasser, 1980; Maringoni et al., 1986; Quezado-Soares \& Lopes, 1999), como de pimentão (Carmo et al., 2001; Marco \& Stall, 1983). O aparecimento de isolados resistentes a esses princípios ativos é apontado como a principal causa dessa ineficiência.

Diferenças em sensibilidade à estreptomicina entre isolados de Xanthomonas causando mancha-bacteriana foram primeiramente observadas na Flórida, EUA, no início dos anos 60 (Stall \& Thayer, 1962; Thayer \& Stall, 1961). Minsavage et al. (1990) analisaram uma coleção de estirpes dos EUA e de outros países e encontraram alta freqüência de isolados resistentes em regiões onde o uso do antibiótico era intenso. $\mathrm{Na}$ ocasião, dos nove isolados provenientes do Brasil, três foram considerados resistentes. Ritchie \& Dittapongpitch (1991) e Sahin \& Miller (1996) encontraram 30\% e 49\% de isolados resistentes originários, respectivamente, da Carolina do Norte e de Ohio, EUA. Isolados resistentes à estreptomicina também foram encontrados no Caribe e na América Central (Bouzar et al., 1999; O’Garro, 1998). Por outro lado, na Itália, onde o uso desse antibiótico não é permitido, nenhum isolado resistente foi detectado entre isolados de (Buonaurio et al., 1994). Atualmente, devido a diversos fatores ligados ao custo, eficiência, proteção ambiental e saúde humana, o uso de antibióticos agrícolas nos EUA é restrito, diferentemente do Brasil, sendo permitido apenas para o controle de Erwinia amylovora em pomares de maçã e pêra, bacterioses em plantas ornamentais e na produção de mudas (McManus \& Stockwell, 2002). Genes de resistência à estreptomicina em Xanthomonas spp. associadas à mancha-bacteriana podem ocorrer em plasmídeos de diferentes tamanhos e no cromossomo (Cooksey, 1990).

Ao contrário da estreptomicina, ainda não há relatos de resistência à oxitetraciclina em Xanthomonas associadas à mancha-bacteriana. Porém, isolados resistentes foram detectados em Pseudomonas syringae pv. syringae procedentes de pomares de pêra em Oregon, EUA (Spotts \& Cervantes, 1995). 
O primeiro relato de resistência ao cobre deu-se em 1983 na Flórida (Marco \& Stall, 1983). No entanto, a resistência ao metal deveria estar presente nas populações bacterianas, já que isolados coletados anteriormente também se mostraram resistentes (Cooksey, 1990). No México, isolados resistentes foram obtidos de plantas de pimentão procedentes de áreas de produção onde o metal tem sido usado por mais de 30 anos (Adaskaveg \& Hine, 1985). Nos estudos realizados na Itália e nos EUA mencionados anteriormente, $45 \%$ e $38 \%$ dos isolados, respectivamente, foram considerados resistentes ao cobre (Buonaurio et al., 1994; Ritchie \& Dittapongpitch, 1991; Sahin \& Miller, 1996). No Caribe e América Central, a porcentagem de isolados resistentes ao cobre foi variável com a região (Bouzar et al., 1999; O’Garro, 1998). No Brasil, Aguiar et al. (2000) detectaram isolados de Xanthomonas spp. associados à mancha-bacteriana do tomate e pimentão resistentes ao cobre originados principalmente dos estados do Rio de Janeiro e de São Paulo. Tanto em bactérias fitopatogênicas como em saprofíticas, a resistência ao cobre pode ser mediada por genes encontrados em plasmídeos ou no cromossomo (Cooksey, 1990; Cooksey et al., 1990; Lee et al., 1994; Voloudakis et al., 1993). O plasmídeo $\mathrm{pXvCu}$, de cerca de $200 \mathrm{~kb}$, foi o primeiro identificado como responsável pela resistência ao metal em Xanthomonas spp. associadas à manchabacteriana na Flórida (Stall et al., 1986).

Este trabalho teve como objetivo avaliar a freqüência de isolados resistentes ao cobre e aos antibióticos estreptomicina e oxitetraciclina em amostras de populações de $X$. axonopodis pv. vesicatoria, $X$. vesicatoria e ' $X$. gardneri' oriundas de campos comerciais de tomateiro destinados ao processamento industrial no Brasil-Central e Nordeste.

\subsection{MATERIAL E MÉTODOS}

Trezentos e sessenta e dois isolados pertencentes às espécies $X$. axonopodis pv. vesicatoria, X. vesicatoria e 'X. gardneri' foram analisados (Tabela 1). Para a obtenção dos isolados, folhas e frutos apresentando sintomas de mancha-bacteriana foram coletados em campos com alta incidência da doença (50-100\% das plantas infectadas) localizados nas macro-regiões produtoras Brasil-Central e Nordeste, a partir de 1995 
(Tabela 1). A classificação dos isolados em nível de espécies, grupos de perfis genômicos através da eletroforese de campo pulsado (PFGE) e raças foi realizada conforme descrito nos capítulos 3, 4 e 5 .

Para a realização dos testes, isolados mantidos em tampão fosfato foram transferidos para meio NA e incubados por 48 horas a $28^{\circ} \mathrm{C}$. A massa bacteriana coletada com uma alça de platina de $3 \mathrm{~mm}$ de diâmetro foi dissolvida em $10 \mathrm{ml}$ de água destilada estéril para o preparo de uma suspensão de células. Alíquotas de $5 \mu$ desta suspensão foram depositadas em triplicata sobre meio AN suplementado com sulfato de cobre $\left(\mathrm{CuSO}_{4} .5 \mathrm{H}_{2} \mathrm{O}\right.$ - Merk, Rio de Janeiro), sulfato de estreptomicina (Sigma, St. Louis, EUA) ou cloridrato de oxitetraciclina (Pfizer, Guarulhos) nas concentrações finais desejadas. Para o sulfato de cobre, foram utilizadas as concentrações de $200 \mu \mathrm{g} / \mathrm{ml}$ (Bouzar et al., 1999) e de $50 \mu \mathrm{g} / \mathrm{ml}$. O produto foi dissolvido em água destilada por agitação por 20 min. e adicionado ao meio antes de sua autoclavagem. $\mathrm{O}$ pH do meio foi então ajustado para 7,0 - 7,2 com NaOH (Rinaldi, 1998). Os antibióticos cloridrato de oxitetraciclina e sulfato de estreptomicina foram utilizados na concentração de $25 \mu \mathrm{g} / \mathrm{ml}$ (Bouzar et al., 1999). Isolados que demonstraram resistência à estreptomicina nessa concentração foram posteriormente testados à concentração de $200 \mu \mathrm{g} / \mathrm{ml}$. Foram preparadas soluções-estoques do antibiótico filtradas em filtro Millex - GS de 0,22 $\mu \mathrm{m}$ (Milipore Co., Bedford, EUA) que foram adicionadas assepticamente no momento em que o meio foi vertido nas placas de petri (Rinaldi, 1998). A viabilidade de todos os isolados foi concomitantemente avaliada em meio AN não-suplementado com agentes químicos. As placas foram incubadas por 96 horas a $28^{\circ} \mathrm{C}$. Após esse período, foi feita a avaliação considerando-se como resistentes isolados que apresentaram crescimento confluente em três repetições. A porcentagem da população composta por isolados resistentes foi calculada para cada espécie e eventos de coleta.

\subsection{RESULTADOS E DISCUSSÃO}

Nenhum isolado mostrou-se resistente à oxitetraciclina. Este fato pode ser devido à ausência de pressão de seleção para resistência devido a não utilização deste princípio ativo nessas lavouras. Relatos de resistência à esse composto são escassos, 
havendo apenas um relato em Pseudomonas syringae pv. syringae procedente de pomares de pêra nos EUA, onde empregava-se o antibiótico (Spotts \& Cervantes, 1995). No caso da estreptomicina, por outro lado, as freqüências de isolados resistentes foram elevadas em ' $X$. gardneri', (98\%) e em $X$. axonopodis pv. vesicatoria (38\%), porém baixa em $X$. vesicatoria (2\%) (Tabela 1, Figura 1). Vale ressaltar que todos os isolados de $X$. axonopodis pv. vesicatoria, identificados como raça T3 (capítulo 5) e coletados em Juazeiro, Petrolina e Orocó, foram sensíveis ao antibiótico. Isolados dessa raça encontrados na Flórida (Jones et al., 1995) e no México (Bouzar et al., 1996) também se mostraram sensíveis.

Sessenta e oito porcento de 66 isolados resistentes a $25 \mu \mathrm{g} / \mathrm{ml}$ de estreptomicina também o foram a $200 \mu \mathrm{g} / \mathrm{ml}$, sendo $100 \%$ dos isolados de X. axonopodis pv. vesicatoria (22/22) e de $X$. vesicatoria (2/2) e 51\% (21/41) dos isolados de ' $X$. gardneri'. A presença de isolados resistentes à estreptomicina no Brasil já havia sido relatada por Minsavage et al. (1990), mas sem menção da hospedeira e da origem desses isolados. Em geral, no caso de antibióticos da família da estreptomicina, segundo Davies (1986), citado por Minsavage et al. (1990), a resistência se manifesta apenas em baixos níveis de concentração do antibiótico. No entanto, este estudo revelou a existência de um grupo de isolados resistentes a uma concentração maior do produto $(200 \mu \mathrm{g} / \mathrm{ml})$, o que pode indicar a existência de um outro mecanismo de resistência (Misavage et al., 1990). Níveis diferenciais de resistência à estreptomicina por Xanthomonas spp. associadas à mancha-bacteriana foram relatados anteriormente (Ritchie \& Dittapongpitch, 1991; Sahin \& Miller, 1996). 
Tabela 1. Número de isolados resistentes ao cobre $(50 \mu \mathrm{g} / \mathrm{ml})$ e estreptomicina (25 $\mu \mathrm{g} / \mathrm{ml})$ de espécies de Xanthomonas causando mancha-bacteriana ${ }^{1}$ em tomateiro para processamento industrial.

\begin{tabular}{|c|c|c|c|c|c|c|c|c|c|c|c|c|c|c|}
\hline \multirow{3}{*}{ Ano } & \multirow{3}{*}{ Local } & \multirow[b]{3}{*}{ Total } & & & & \multicolumn{9}{|c|}{ Número de isolados resistentes } \\
\hline & & & \multicolumn{3}{|c|}{ Total espécies } & \multicolumn{3}{|c|}{ Cobre } & \multicolumn{3}{|c|}{ Estreptomicina } & \multicolumn{3}{|c|}{$C+E^{2}$} \\
\hline & & & XAV & XV & $\mathrm{XG}$ & XAV & XV & $\mathrm{XG}$ & XAV & XV & $\mathrm{XG}$ & XAV & XV & $\mathrm{XG}$ \\
\hline \multicolumn{15}{|c|}{ Brasil-Central } \\
\hline \multicolumn{15}{|c|}{ Goiás } \\
\hline 1995 & Itapaci & 93 & 2 & 91 & - & 0 & 67 & - & 1 & 0 & - & 0 & 0 & - \\
\hline 1997 & Itapaci & 22 & - & 2 & 20 & - & 2 & 11 & - & 2 & 18 & - & 2 & 10 \\
\hline 1997 & Rio Verde & 47 & - & - & 47 & - & - & 9 & - & - & 46 & - & - & 9 \\
\hline 1998 & Morrinhos & 68 & 6 & - & 62 & 0 & - & 25 & - & - & 61 & 0 & - & 25 \\
\hline 2000 & Morrinhos & 64 & - & - & 64 & - & - & 49 & - & - & 64 & - & - & 49 \\
\hline \multicolumn{15}{|c|}{ Minas Gerais } \\
\hline 1998 & Patos de Minas & 11 & - & - & 11 & - & - & 3 & - & - & 11 & - & - & 3 \\
\hline \multicolumn{15}{|c|}{ Nordeste } \\
\hline \multicolumn{15}{|c|}{ Pernambuco } \\
\hline 1996 & Petrolina & 36 & 36 & - & - & 1 & - & - & 34 & - & - & 1 & - & - \\
\hline 1998 & Petrolina & 18 & 18 & - & - & 1 & - & - & 0 & - & - & 0 & - & - \\
\hline 1998 & Orocó-PE & 10 & 10 & 0 & 0 & 0 & - & - & 0 & - & - & 0 & - & - \\
\hline \multicolumn{15}{|c|}{ Bahia } \\
\hline 1998 & Abaré & 16 & 16 & - & - & 2 & - & - & 0 & - & - & 0 & - & - \\
\hline 1998 & Juazeiro & 4 & 4 & - & - & 0 & - & - & 0 & - & - & 0 & - & - \\
\hline & Total & 389 & 92 & 93 & 204 & 4 & 69 & 97 & 35 & 2 & 200 & 1 & 2 & 96 \\
\hline
\end{tabular}

1. XAV: Xanthomonas axonopodis pv. vesicatoria; XV: X. vesicatoria; XG: 'X. gar XAV: Xanthomonas axonopodis pv. vesicatoria; XV: $X$. vesicatoria; XG: 'X. gardneri'. Os isolados de XAV dos campos de Juazeiro, Petrolina e Orocó são raça T3, enquanto os demais XAV são raça T1. Isolados XV e XG são raça T2 (capítulo 5).

2. $\mathrm{C}+\mathrm{E}$ : isolados que foram resistentes no teste com cobre $(50 \mu \mathrm{g} / \mathrm{ml})$ e no teste com estreptomicina $(25$ $\mu \mathrm{g} / \mathrm{ml})$.

“_“": presença da espécie não foi constatada.

$\mathrm{Na}$ tabela 2 foram compilados os dados relativos à coleta realizada no município de Morrinhos em 1998, onde três lavouras localizadas em duas propriedades (lavouras "A" e "B" na fazenda Córrego Fundo e "C" na fazenda Campo Alegre) foram amostradas em dois períodos no mesmo ciclo da cultura. Nessas lavouras foram realizadas várias pulverizações com produtos à base de cobre e duas a três com o antibiótico estreptomicina. A alta freqüência de isolados resistentes à estreptomicina (88 
a $100 \%$ ), tanto na primeira como na segunda amostragem de cada lavoura ("A", "B" e “C”), provavelmente se explica pela existência de uma população inicial já resistente. $\mathrm{O}$ fato de que as plântulas utilizadas nos três plantios tiveram a mesma procedência, aliado à detecção de isolados resistentes na fase de plântula na fazenda Campo Alegre (lavoura “C”), reforçam essa hipótese. Nesse caso, a utilização da estreptomicina como tentativa do controle da mancha-bacteriana já estava fadada ao insucesso. A permanência de isolados resistentes nos referidos campos dependeria de fatores relacionados às práticas culturais (rotação, eliminação de plantas voluntárias, restos culturais, etc.) e da estabilidade da resistência ao agente químico na ausência da pressão de seleção caso o uso do antibiótico viesse a ser descontinuado. Em $P$. syringae pv. syringae, por exemplo, o fato de a resistência à estreptomicina ser altamente estável in vitro explica a sua persistência em pomares de pêra independentemente do regime de bactericidas empregados (Spotts \& Cervantes, 1995).

Tabela 2. Freqüência de isolados resistentes ao cobre $(50 \mu \mathrm{g} / \mathrm{ml})$ e à estreptomicina $(25$ $\mu \mathrm{g} / \mathrm{ml})$ em testes in vitro. Coleta de Morrinhos em 1998.

\begin{tabular}{|c|c|c|c|c|c|c|c|}
\hline Fazenda & Estádio $^{1}$ & Área $^{2}$ & $\begin{array}{l}\text { Variedades } \\
\text { amostradas }^{3}\end{array}$ & $\begin{array}{c}\text { No. de } \\
\text { isolados }\end{array}$ & $\begin{array}{c}\text { Cobre } \\
(\%)\end{array}$ & $\begin{array}{c}\text { Estreptomicina } \\
(\%)\end{array}$ & Controle químico ${ }^{4}$ \\
\hline \multirow[t]{4}{*}{ Córrego Fundo } & 40 dias & A & $\begin{array}{l}\text { Hypeel } 45, \\
\text { Hypeel } 108\end{array}$ & 9 & 11 & 88 & OC (4) \\
\hline & 100 dias & & Hypeel 45 & 15 & 100 & 100 & $\begin{array}{c}\mathrm{OC}(6) \\
\mathrm{HC}(3) \\
\mathrm{E}(3)\end{array}$ \\
\hline & 20 dias & $\mathrm{B}$ & Hypeel 108 & 5 & 20 & 100 & $\begin{array}{l}\mathrm{OC}(2) \\
\mathrm{OC}(4)\end{array}$ \\
\hline & 80 dias & & Hypeel 108 & 9 & 22 & 100 & $\begin{array}{c}\mathrm{HC}(3) \\
\mathrm{E}(3)\end{array}$ \\
\hline \multirow[t]{2}{*}{ Campo Alegre } & $0 \operatorname{dias}^{5}$ & $\mathrm{C}$ & Hypeel 45 & 6 & 0 & 100 & $\begin{array}{c}\mathrm{E}(1-2) \\
\mathrm{OC}+\mathrm{M}(6)\end{array}$ \\
\hline & 60 dias & & Hypeel 45 & 26 & 15 & 100 & $\begin{array}{c}\text { E (2) } \\
\text { OC (7) }\end{array}$ \\
\hline
\end{tabular}

1. Dias após o transplantio.

2. Áreas dentro do pivô com plantios e tratamentos fitossanitários realizados na mesma época.

3. Variedades híbridas plantadas.

4. Utilização de princípios ativos com ação para a mancha-bacteriana. Os tratamentos foram iniciados na mesma data para todas as áreas e referem-se ao período entre o transplantio e o evento de coleta das amostras. $\mathrm{E}=$ estreptomicina; $\mathrm{OC}=$ oxicloreto de cobre; $\mathrm{HC}=$ hidróxido de cobre; $\mathrm{OC}+\mathrm{M}=$ oxicloreto de cobre misturado ao mancozeb.

5. Amostragem feita em plântulas em bandejas de isopor no campo no dia do transplantio. 
Nenhum isolado de Xanthomonas mostrou-se resistente ao cobre na concentração de $200 \mu \mathrm{g} / \mathrm{ml}$. No entanto, isolados resistentes foram detectados em uma concentração mais baixa $(50 \mu \mathrm{l} / \mathrm{ml})$. O crescimento bacteriano em meio de cultura suplementado com $200 \mu \mathrm{g} / \mathrm{ml}$ do metal tem sido utilizado para testar a resistência de isolados de Xanthomonas associadas à mancha-bacteriana (Bouzar et al., 1999; Ritchie \& Dittapongpitch, 1991). A quantidade que estará disponível e que terá o efeito tóxico, no entanto, é variável de acordo com a capacidade do meio em complexar o cobre (Menkissoglu \& Lindow, 1991). Resistência a teores baixos de cobre, como a detectada no presente trabalho, também foi observada em Xanthomonas associadas à manchabacteriana do pimentão (Sahin \& Miller, 1996), X. axonopodis pv. citri (Rinaldi, 1998), P. syringae pv. syringae (Spotts \& Cervantes, 1995) e P. syringae pv. tomato (Silva \& Lopes, 1995). Estudos genéticos realizados com X. campestris pv. juglandis (Pierce) Dye revelaram um operon envolvido na resistência ao metal composto por quatro ORFs (“open reading frame") (Lee et al., 1994). Em isolados mutantes onde apenas a ORF1 e a ORF2 são expressas, a resistência manifestou-se apenas em concentração baixa do metal no meio. A ocorrência de um sistema semelhante em isolados selvagens, como os analisados neste estudo, ainda está por ser avaliada.

Considerando-se as três espécies em conjunto, a freqüência de isolados resistentes ao cobre foi inferior à da estreptomicina e superior à freqüência de isolados resistentes aos dois princípios ativos (Figura 1). A freqüência de isolados resistentes foi de $48 \%, 4 \%$ e $74 \%$ respectivamente para ' $X$. gardneri', $X$. axonopodis pv. vesicatoria e $X$. vesicatoria (Figura 1). A maior freqüência de isolados resistentes ao cobre foi detectada na macro-região Brasil-Central $(98 \%, 166 / 170)$, de onde originaram-se todos os isolados de ' $X$. gardneri' e a maioria dos isolados de $X$. vesicatoria (Tabela 1). A ocorrência de isolados resistentes ao cobre em campos de tomate e de pimentão também tem sido relatada por vários autores (Adaskaveg et al., 1985; Aguiar et al., 2000; Buonaurio et al., 1994; Bouzar et al., 1999; Marco \& Stall, 1983; Minsavage et al. 1990; O’Garro, 1998; Ritchie \& Dittapongpitch, 1991). Porém, apenas alguns relatos entre os mais recentes classificam os isolados com relação às espécies a que pertencem (Jones et al., 2000). Bouzar et al. (1999), por exemplo, estudaram a diversidade genética de 
isolados do Caribe e da América Central, encontrando a predominância de isolados do grupo A ( $=$ X. axonopodis pv. vesicatoria), que eram na maioria resistentes ao cobre e também à estreptomicina. $\mathrm{O}$ conhecimento dessa característica fenotípica, aliado ao conhecimento da espécie pode auxiliar na determinação da origem dos isolados. Estudos posteriores podem elucidar se os genes envolvidos na resistência encontrada em isolados de diferentes espécies compartilham a mesma história evolutiva e se derivam ou não dos genes de resistência do plasmídeo pXvCu (Stall et al., 1986).

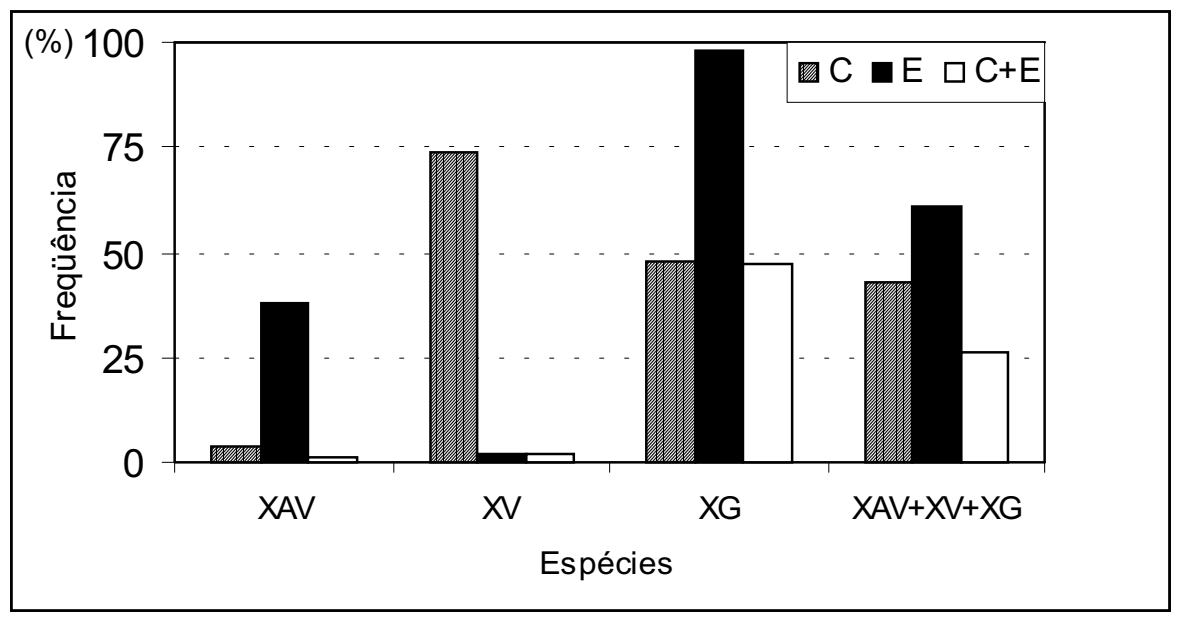

Figura 1 - Freqüência de isolados das espécies de Xanthomonas que causam manchabacteriana em tomateiro resistentes ao cobre na concentração de $50 \mu \mathrm{g} / \mathrm{ml}$ (C), à estreptomicina a $25 \mu \mathrm{g} / \mathrm{ml}$ (E) e aos dois princípios ativos (C+E), nas respectivas concentrações. XAV: Xanthomonas axonopodis pv. vesicatoria; $\mathrm{XV}: X$. vesicatoria; XG: 'X. gardneri'.

Ainda em relação ao cobre, a análise dos dados relativos às coletas nas fazendas Córrego Fundo e Campo Alegre, no município de Morrinhos em 1998, evidenciou um aumento na proporção de isolados resistentes ao longo do tempo nas lavouras "A" e "C" (Tabela 2). Esse aumento talvez tenha sido resultado da pressão de seleção exercida pelo emprego do metal. O mesmo não foi constatado para a lavoura "B", onde a proporção permaneceu estável (Tabela 2). Nessa lavoura, além do menor número de pulverizações 
até o momento da segunda amostragem (duas a menos do que a lavoura "A" na mesma fazenda), outros fatores como a variedade plantada, estádio das plantas ou problemas de amostragem podem estar relacionados ao resultado obtido (Tabela 2).

A exemplo de outros países, as perspectivas do controle da mancha-bacteriana pelo emprego de estreptomicina e de produtos à base de cobre não são muito promissoras para a cultura do tomateiro rasteiro no Brasil. Apesar de alguns campos do Nordeste estarem aparentemente livres de isolados resistentes a esses princípios ativos, uma eventual introdução desse tipo de isolado via sementes contaminadas poderá resultar em populações predominantemente resistentes com conseqüente insucesso no controle da doença. Potencialmente, o mesmo pode vir a ocorrer com a oxitetraciclina ou outro antibiótico que venha a obter registro de uso na cultura. Assim, outras medidas tais como uso de sementes e plântulas livres dos patógenos, variedades resistentes ou mais tolerantes e rotação de culturas devem ser adotadas. 


\section{CONCLUSÕES GERAIS}

As três espécies de Xanthomonas associadas à mancha-bacteriana relatadas na literatura ocorreram em campos comerciais de tomate para processamento industrial no Brasil no período de 1995 a 2000. Este é o primeiro relato de epidemias causadas por 'Xanthomonas gardneri' no mundo e o primeiro relato da raça T3 no Brasil. Isolados dessa raça foram tentativamente classificados como um subgrupo da espécie $X$. axonopodis pv. vesicatoria. A ocorrência das combinações T1P8 em X. axonopodis pv. vesicatoria e T2P7 e T2P8 em 'X. gardneri', também são relatadas no país pela primeira vez.

A análise da diversidade genética conduzida neste trabalho, além de ressaltar que populações de Xanthomonas associadas à mancha-bacteriana foram em geral clonais, com exceção de algumas populações na variedade de polinização aberta IPA-5, atestou o efeito significativo do tipo de variedade plantada nas estruturas populacionais. Menor diversidade haplotípica intra-populacional em relação à total foi encontrada nas variedades híbridas importadas do que nas de polinização aberta nacionais, o que talvez seja indicação de que essas populações, notadamente de ' $X$. gardneri' e de $X$. axonopodis pv. vesicatoria raça T3, originaram-se de eventos de introdução recentes.

Em algumas situações, a presença de certas espécies/grupos genéticos em determinado ano ou início de ciclo da cultura e a não detecção das mesmas em anos posteriores ou final do mesmo ciclo, é uma evidência de que há diferencial adaptativo e/ou competição entre as espécies/grupos genéticos.

As perspectivas do controle da mancha-bacteriana pelo emprego de estreptomicina e, em menor extensão, de produtos à base de cobre não são muito promissoras para a cultura do tomateiro rasteiro no Brasil, já que resistência in vitro foi detectada entre os isolados de Xanthomonas. $\mathrm{O}$ fato de todos os isolados analisados da 
raça T3 terem sido sensíveis ao antibiótico estreptomicina, corrobora para a hipótese mencionada acima de uma introdução recente desta raça no país, provavelmente de um local onde o uso deste produto é proibido.

Os resultados obtidos no presente trabalho norteiam algumas ações que devem ser iniciadas à curto prazo, tais como, a introgressão do gene de resistência $X v 3$ da linhagem 'NIL 216' na cultivar IPA-5 ou Viradoro (derivada da IPA-5 com resistência a tospovírus) para plantios no Nordeste; avaliação de bancos de germoplasma para detecção de fontes de resistência qualitativa e quantitativa para as raças T1, T2 e T3; análise da sanidade de sementes nacionais e importadas, aprimoramento de técnicas de detecção em sementes/mudas dos quatro grupos genéticos de Xanthomonas associados à mancha-bacteriana; avaliação do desenvolvimento de resistência à estreptomicina na raça T3 e avaliação de outros produtos alternativos para controle em campo. 


\section{REFERÊNCIAS BIBLIOGRÁFICAS}

ADASKAVEG, J.E.; HINE, R.B. Copper tolerance and zinc sensitivity of Mexican strains of Xanthomonas campestris pv. vesicatoria, causal agent of bacterial spot of pepper. Plant Disease, v.69, n.11, p.993-996, 1985.

ADHIKARI, T.B.; MEW, T.W.; LEACH, J.E. Genotypic and pathotypic diversity in Xanthomonas oryzae pv. oryzae in Nepal. Phytopathology, v.89, n.7, p.687-694, 1999.

AGRIOS, G.N. Plant Pathology 4.ed. San Diego: Academic Press, 1997. 635p.

AGUIAR, L.; KIMURA, O.; CASTILHO, A.M.C.; CASTILHO, K.S.C.; RIBEIRO, R.L.D.; AKIBA, F.; CARMO, M.G.F. Resistência ao cobre em isolados nacionais de Xanthomonas campestris pv. vesicatoria de pimentão e tomateiro. Agronomia, v.34, n.1/2, p. $78-82,2000$.

ASTUA-MONGE, G.; MINSAVAGE, G.V.; STALL, R.E.; DAVIS, M.J.; BONAS, U.; JONES, J.B. Resistance of tomato and pepper to T3 strains of Xanthomonas campestris pv. vesicatoria is specified by a plant-inducible avirulence gene. Molecular Plant-Microbe Interactions, v.13, n.9, p.911-921, 2000a.

ASTUA-MONGE, G.; MINSAVAGE, G.V.; STALL, R.E.; VALLEJOS, C.E.; DAVIS, M.J.; JONES, J.B. Xv4-vrxv4: a new gene-for-gene interaction identified between Xanthomonas campestris pv. vesicatoria race $\mathrm{T} 3$ and the wild tomato relative Lycopersicon pennellii. Molecular Plant-Microbe Interactions, v.13, n.12, p.1346$1355,2000 \mathrm{~b}$. 
BALlVORA, A.; PIERRE, M.; ACKERVEKEN, G.; SEBASTIAN, S.; ROSSIER, O.; GANAL, M.; LAHYE, T.; BONAS, U. Genetic mapping and functinal analysis of the tomato Bs4 locus governing recognition of the Xanthomonas campestris pv. vesicatoria AvrBs4 protein. Molecular Plant-Microbe Interactions, v.14, n.14, p.629-638, 2001.

BARBOSA, V. The processing tomato growing system under tropical and subtropical conditions - the Brazilian experience. In: INTERNATIONAL CONFERENCE ON THE PROCESSING TOMATO, 1., Recife, 1996. Proceedings. Recife: IPA/ASHS, 1997. p.94-97.

BASHAN, Y.; OKON, Y. Internal and external infections of fruits and seeds of peppers by Xanthomonas campestris pv. vesicatoria. Canadian Journal of Botany, v.64, n.12, p.2865-2871, 1986.

BASHAN, Y.; OKON, Y.; HENIS, Y. Long-term survival of Pseudomonas syringae pv. tomato and Xanthomonas campestris pv. vesicatoria in tomato and pepper seeds. Phytopathology, v.72, n.9, p.1143-1144, 1982.

BEAUliEU, C.; MINSAVAGE, G.V.; CANTEROS, B.I.; STALL, R.E. Biochemical and genetic analysis of a pectate lyase gene from Xanthomonas campestris p. vesicatoria. Molecular Plant-Microbe Interactions, v.4, n.5, p.446-451, 1991.

BEYNON, J.L. Molecular genetics of disease resistance: an end to the 'Gene-for-Gene' concept? In: CRUTE, I.R.; HOLUB, E.B.; BURDON, J.J. (Ed.). The gene-for-gene relationship in plant-parasite interactions. Wallingford: CAB International, 1997. p.359-378.

BRADBURY, J.F. Guide to Plant Pathogenic Bacteria. Slough: C.A.B. International, 1993. 332p. 
BONAS, U.; CONRADS-STRAUCH, J.; BALBO, I. Resistance in tomato to Xanthomonas campestris pv. vesicatoria is determined by alleles of the pepperspecific avirulence gene avrBs3. Molecular General Genetics, v.238, p.261-269, 1993.

BONGIOLO NETO, A.; REIFSCHNEIDER, F.J.B.; TAKATSU, A. Levantamento de grupos de Xanthomonas campestris pv. vesicatoria no Brasil. Fitopatologia Brasileira, v.11, n.2, p.881-889, 1986.

BOUZAR, H.; JONES, J.B.; MINSAVAGE, G.V.; STALL, R.E.; SCOTT, J.W. Proteins unique to phenotypically distinct groups of Xanthomonas campestris pv. vesicatoria revealed by silver staining. Phytopathology, v.84, n.1, p.39-44, 1994a.

BOUZAR, H.; JONES, J.B.; STALL, R.E.; HODGE, N.C.; MINSAVAGE, G.V.; BENEDICT, A.A.; ALVAREZ, A.M. Physiological, chemical, serological, and pathogenic analysis of a worldwide collection of Xanthomonas campestris pv. vesicatoria. Phytopathology, v. 84, n.7, p.663-671, 1994 b.

BOUZAR, H.; JONES, J.B.; SOMODI, G.C.; STALL, R.E.; DAOUZLI, N.; LAMBE,

R.C.; FELIX-GASTELUM, R.; TRINIDAD-CORREA, R. Diversity of Xanthomonas campestris pv. vesicatoria in tomato and pepper fields of Mexico. Canadian Journal of Plant Pathology, v.18, n. 1, p.75-77, 1996.

BOUZAR, H.; JONES, J.B.; STALL, F.J.; LOUWS, F.J.; SCHNEIDER, M.; RADEMAKER, J.L.W.; BRUIJN, de; JACKSON, L.E. Multiphasic analysis of xanthomonads causing bacterial spot disease on tomato and pepper in the Caribbean and Central America: evidence for common lineages within and between countries. Phytopathology, v,89, n.4, p.328-335, 1999. 
BUONAURIO, R.; STRAVATO, V.M.; SCORTICHINI, M. Characterization of Xanthomonas campestris pv. vesicatoria from Capsicum annuum L. in Italy. Plant Disease, v.78, n.3, p.296-299, 1994.

BURKHOLDER, W.H.; LI, C.C. Variations in Phytomonas vesicatoria. Phytopathology, v.31, n.8, p.753-755, 1941.

CANTEROS, B.I.; MINSAVAGE, G.V.; JONES, J.B.; STALL, R.E. Diversity of plasmids in Xanthomonas campestris pv. vesicatoria. Phytopathology, v.85, p.1260$1265,1995$.

CANTEROS, B.I.; MINSAVAGE, G.; BONAS, U.; PRING, D.; STALL, R.E. A gene from Xanthomonas campestris pv. vesicatoria that determines avirulence in tomato is related to avrBs3. Molecular Plant-Microbe Interactions, v.4, n.6, p.628-632, 1991.

CARELLI, M.; GNOCCHI, S.; FANCELLI, S.; MENGONI, A.Sinorhizobium meliloti populations nodulating different alfalfa cultivars in Italian soils. Applied and Environmental Microbiology, v.66, n.11, p.4785-4789, 2000.

CARMO, M.G.F.; MACAGNAN, D.; CARVALHO, A. O. Progresso da manchabacteriana do pimentão a partir de diferentes níveis iniciais de inóculo e do emprego ou não do controle com oxicloreto de cobre. Horticultura brasileira, v.19, n.3, p.342-347, 2001.

CIESIOLKA, L.D.; HWIN, T.; GEARLDS, J.D.; MINSAVAGE, G.V.; SAENZ, R.; BRAVO, M.; HANDLEY, V.; CONOVER, S.M.; ZHANG, H.; CAPORGNO, J.; PHENGRASAMY, N.B.; TOMS, A.O.; STALL, R.E.; WHALEN, M.C. Regulation of expression of avirulence gene $a v r R x v$ and identification of a family of host interaction factors by sequence analysis of $a v r B s T$. Molecular Plant-Microbe Interactions, v.12, n.1, p.35-44, 1999. 
COELHO, A. S. G. BOOD: Avaliação de dendrogramas baseada em estimativas de distâncias/similaridades genéticas através do procedimento de bootstrap. (software). ver.1,0. Goiânia: Laboratório de Genética Vegetal - DBG/ICB/UFG, 2000. 1v

COOK, A.A.; STALL, R.E. Differentiation of pathotypes among isolates of Xanthomonas vesicatoria. Plant Disease Reporter, v.53, n.8, p.617-619, 1969.

COOKSEY, D. A. Genetics of bactericide resistance in plant pathogenic bacteria. Annual Review of Phytopathology, v.28, p.201-219, 1990.

COOKSEY, D.A.; GRAHAM, J.H. Genomic fingerprinting of two pathovars of phytopathogenic bacteria by rare-cutting restriction enzymes and field inversion gel electrophoresis. Phytopathology, v.79, n.7, p.745-750, 1989.

COOKSEY, D.A.; AZAD, H.R.; CHA, J.; LIM, C. Copper resistance gene homologs in pathogenic and saprophytic bacterial species from tomato. Applied and Environmental Microbiology, v.56, n.2, p.431-435, 1990.

COPLIN, D.; MAJERCZAK, D.R.; ZHANG, Y.; KIM, W-S. K.; JOCK, S.; GEIDER, K. Identification of Pantoea stewartii subsp. stewartii by PCR and strain differentiation by PFGE. Plant Disease, v.86, n.3, p.304-311, 2002.

CRUTE, I.A.; PINK, A.C. Genetics and utilization of pathogen resistance in plants. The Plant Cell, v.8, n.10, p.1747-1755, 1996.

CUPPELS, D.; KELMAN, A. Evaluation of selective media for isolation of soft-rot bacteria from soil and plant tissue. Phytopathology, v.64, n.4, p.468-475, 1974.

DAHLBECK, D.; STALL, R.E. Mutations for change of race in cultures of Xanthomonas vesicatoria. Phytopathology, v.69, n.6, p.634-636, 1979. 
DALMASTRI, C.; CHIARINI, L.; CANTALE, C.; BEVIVINO, A.; TABACCHIONI, S. Microbial Ecology, v.38, p.273-284, 1999.

DYE, D.W. Cultural and biochemical reactions of additional Xanthomonas spp. New Zealand Journal of Science, v.9, n.4, p.913-919, 1966.

EGEL, D.S.; GRAHAM, J.H.; STALL, R.E. Genomic relatedness of Xanthomonas campestris strains causing disease on citrus. Applied Environmental Microbiology, v.57, p.2724-2730, 1991.

EXCOFFIER, L.; SMOUSE, P.E; QUATTRO, J.M. Analysis of molecular variance inferred from metric distances among DNA haplotypes: application to human mitochondrial DNA restriction data. Genetics, v.131, n.6, p.479-491, 1992.

FRY, W.E. Principles of Plant Disease Management. Orlando: Academic Press, 1982, 378p.

GARDNER, M.W.; KENDRICK, J.B. Bacterial spot of tomato and pepper. Phytopathology, v.13, n.7, p.307-315, 1923.

GARRITY, G.M.; HOLT, J.G. An overview of the road map to the manual. Systematic Bacteriology. 2.ed. New York: Springer, 2000. 20p. (Bergey's Manual)

GIORDANO, L.B; SILVA, J.B.; BARBOSA, V. Produção Mundial e Nacional. In: SILVA, J.B.C; GIORDANO, L.B. (Ed.). Tomate para processamento industrial. Brasília: Embrapa Comunicação para Transferência de Tecnologia / Embrapa Hortaliças, 2000. p. 36-59.

GITAITIS, R.; McCARTER, S.; JONES, J.B. Disease control in tomato transplants produced in Georgia and Florida. Plant Disease, v.76, n.7, p.651-656, 1992. 
GOODE, M.J.; SASSER, M. Prevention - the key to controlling bacterial spot and bacterial speck of tomato. Plant Disease, v.64, n.9, p.831-834, 1980.

GOODMAN, R.N.; NOVACKY, A.J. The hypersensitive reaction in plants to pathogens - a resistance phenomenon. St. Paul: APS Press, 1994. 244p.

GOODWIN, S.; ALLARD, R.W.; HARDY, S.A.; WEBSTER, R.K. Hierarchical structure of pathogenic variation among Rhynchosporium secalis populations in Idaho and Oregon. Canadian Journal of Botany, v.70, p.810-817, 1992.

HILDEBRAND, D.C.; PALLERONI, N.J.; SCHROTH, M.N. Deoxyribonucleic acid relatedness of 24 xanthomonad strains representing 23 Xanthomonas campestris pathovars and Xanthomonas fragariae. Journal of Applied Bacteriology, v.68, n.6, p.263-269, 1990.

HUFF, D.R.; PEAKALL, R.; SMOUSE, P.E. RAPD variation within and among natural populations of outcrossing buffalograss [Buchloë dactyloides (Nutt.) Engelm.]. Theoretical Applied Genetics, v.86, p.927-934, 1993.

JONES, A. L.; GEIDER, K. Gram-negative bacteria. Erwinia amylovora group. In: SCHAAD, N. W.; JONES, J. B.; CHUN, W. (Ed). Laboratory Guide for Identification of Plant Pathogenic Bacteria. St Paul: American Phytopathological Society, 2001. p 40-55.

JONES, J.B. Bacterial spot. In: JONES, J.B.; JONES, J.P.; STALL, R.E.; ZITTER, T.A. (Ed.). Compendium of tomato diseases. St. Paul: America Phytopathological Society Press, 1997. p.27.

JONES, J.B.; SCOTT, J.W. Hypersensitive response in tomato to Xanthomonas campestris pv. vesicatoria. Plant Disease, v.70, n.4, p.337-339, 1986. 
JONES, J.B.; STALL, R.E.; BOUZAR, H. Diversity among xanthomonads pathogenic on pepper and tomato. Annual Review of Phytopathology, v.36, p.41-58, 1998a.

JONES, J.B.; STALL, R.E.; SOMODI, G.C.; BOUZAR, H.; HODGE, N.C. A third tomato race of Xanthomonas campestris pv. vesicatoria. Plant Disease, v.79, n.4, p.395-398, 1995.

JONES, J.B.; BOUZAR, H.; SOMODI, G.C.; STALL, R.E.; PERNEZNY, K.; ELMORSY, G.; SCOTT, J.W. Evidence for the preemptive nature of tomato race 3 of Xanthomonas campestris pv. vesicatoria in Florida. Phytopathology, v.88, n.1, p.33$38,1998 b$.

JONES, J.B.; BOUZAR, J.; STALL, R.E.; ALMIRA, E.C.; ROBERTS, P.D.; BOWEN, B.W.; SUDBERRY, J.; STRICKLER, P.M.; CHUN, J. Systematic analysis of xanthomonads (Xanthomonas spp.) associated with pepper and tomato lesions. International Journal of Systematic Bacteriology, v.50, n.5, p.1211-1219, 2000.

KEARNEY, B.; STASKAWICZ, B.J. Widespread distribution and fitness contribution of Xanthomonas campestris avirulence gene avrBs2. Nature, v.346, n.7, 1990.

KOUSIK, C.S.; RITCHIE, D.F. Isolation of pepper races 4 and 5 of Xanthomonas campestris pv. vesicatoria from diseased peppers in southerastern U.S. fields. Plant Disease, v.79, n.5, p.540, 1995. /Resumo/

KOUSIK, C.S.; RITCHIE, D.F. Race shift in Xanthomonas campestris pv. vesicatoria within a season in field-grown pepper. Phytopathology, v.86, n.9, 1996. 
LATERROT, H. Breeding strategies for disease resistance in tomatoes with emphasis on the tropics: current status and research challenges. In: INTERNATIONAL CONFERENCE ON THE PROCESSING TOMATO, 1., Recife, 1996. Proceedings. Recife: IPA/ASHS, 1997. p.126-132.

LEACH, J.E.; WHITE, F.F. Bacterial avirulence genes. Annual Review of Phytopathology, v. 34, p.153-179, 1996.

LEE, Y.; HENDSON, M.; PANOPOULOS, N.J.; SCHROTH, M.N. Molecular cloning, chromosomal mapping, and sequence analysis of copper resistance genes from Xanthomonas campestris pv. juglandis: homology with small blue copper proteins and multicopper oxidase. Journal of Bacteriology, v.176, n.1, p.173-188, 1994.

LEITE, R.P.; EGEL, D.S.; STALL, R.E. Genetic analysis of hrp-related DNA sequences of Xanthomonas campestris strains causing diseases of citrus. Applied and Environmental Microbiology, v.60, p.1078-1086, 1994.

LEITE, R.P.; JONES, J.B.; SOMODI, G.C.; MNSAVAGE, G.V.; STALL, R.E. Detection of Xanthomonas campestris pv. vesicatoria associated with pepper and tomato seed by DNA amplification. Plant Disease, v.79, n.9, p.917-922, 1995.

LOPES, C.A.; QUEZADO-SOARES, A.M.; Doenças bacterianas das hortaliças diagnose e controle. Brasília: Embrapa-CNPH, 1997. 70p.

LOWS, F.J.; RADEMAKER, J.L.W.; BRUIJN, F.J. The three D's of PCR-based genomic analysis of phytobacteria: diversity, detection, and disease diagnosis. Annual Review of Phytopathology, v. 37, p.81-125, 1999. 
LOWS, F.J.; FULBRIGHT, D.W.; STEPHENS, C.T.; BRUIJN, F.J. Differentiation of genomic structure by rep-PCR fingerprinting to rapidly classify Xanthomonas campestris pv. vesicatoria. Phytopathology, v.85, n.5, p.528-536, 1995.

MARCO, G.M.; STALL, R.E. Control of bacterial spot of pepper initiated by strains of Xanthomonas campestris pv. vesicatoria that differ in sensitivity to copper. Plant Disease, v.67, n.7, p.779-781, 1983.

MARINGONI, A.C.; KUROZAWA, C.; BARBOSA, V.; SILVA NETO, J.C. Controle químico da mancha bacteriana (Xanthomonas campestris pv. vesicatoria (Doidge) Dye) do tomateiro (Lycopersicon esculentum Mill.). Summa Phytopathologica, v.12, n.1/2, p.92-101, 1986.

MARQUES, L.L.R. Avaliação de marcadores moleculares para o estudo da diversidade de bactérias Xanthomonas spp. patogênicas para tomate e pimentão. Campinas, 2000. 142p. Tese (Doutorado) - Universidade Estadual de Campinas.

MCDONALD, B.A.; MARTINEZ, J.P. DNA restriction fragment length polymorphisms among Mycosphaerella graminicola (anamorph Septoria tritici) isolates collected from a single wheat field. Phytopathology, v.80, n.12, p.1368-1373, 1990.

MCMANUS, P.; STOCKWELL, V. Antibiotics for plant disease control: silver bullets of rusty sabers? WWW.APSFeatures\APSFea-antibiotics.htm. (08 jun. 2002)

MELO, P.C.T. Retrospectiva da agroindústria do tomate no Brasil nos anos 90. Horticultura brasileira, v.11, n.2, p.109-111, 1993.

MENGONI, A.; BAZZICALUPO, M. The statistical treatment of data and the Analysis of Molecular Variance (AMOVA) in molecular microbial ecology. Annals of Microbiology, v.52, n.2, p.95-102, 2002. 
MENKISSOGLU, O.; LINDOW, S.E. Relationship of fre ionic copper and toxicity to bacteria in solutions of organic compounds. Phytopathology, v.81, n.10, p.1258$1263,1991$.

MINSAVAGE, G.V.; JONES, J.B.; STALL, R.E. Cloning and sequencing of an avirulence gene (avrRxv3) isolated from Xathomonas campestris pv. vesicatoria tomato race 3. Phytopathology, v.86, n.11, pS15, 1996. /Resumo/

MINSAVAGE, G.V.; DAHLBECK, D.; WHALEN, M.C.; KEARNEY, B.; BONAS, U.; STASKAWICZ, B.J.; STALL, R.E. Gene-for-gene relationships specifying disease resistance in Xanthomonas campestris pv. vesicatoria-pepper interactions. Molecular Plant-Microbe Interactions, v.3, n.1, p.41-47, 1990.

MOORE, L.W.; BOUZAR, H.; BURR, T Gram-negative bacteria. Agrobacterium. In: SHAAD. N.W.; JONES, J. B.; CHUN, W. (Ed.) Laboratory guide for identification of plant pathogenic bacteria. St. Paul: America Phytopathological Society Press, 2001. p.17-35.

NEI, M.; LI, W.-H. Mathematical model for studying genetic variation in terms of restriction endonucleases. Proceedings of the National Academy of Sciences USA, v.76, n.10, p.5269-5273, 1979.

OCHIAI, H.; HORINO, O.; MIYAJIMA, K.; KAKU, H. Genetic diversity of Xanthomonas oryzae pv. oryzae strains from Sri Lanka. Phytopathology, v.90, n.4, p.415-421, 2000.

O'GARRO, L.W. Bacterial spot of tomato and pepper on four East Caribbean islands: races, their abundance, distribution, aggressiveness, and prospects for control. Plant Disease, v.82, n.8, p.864-870, 1998. 
O'GARRO, L.W.; GORE, J.P.; FERGUSON, E. Races of Xanthomonas campestris pv. vesicatoria overcoming the gene $B s 2$ for bacterial spot resistance in pepper, prevalent on Capsicum chinense in Barbados and Grenada and weakly pathogenic on bell pepper and tomato in the field. Plant Pathology, v.48, n.5, p.588-594, 1999.

PICARD, C.; DI CELLO, F.; VENTURA, M.; FANI, R.; GUCKERT, A. Frequency and biodiversity of 2,4-Diacetylphloroglucinol-producing bacteria isolated from the maize rhizosphere at different stages of plant growth. Applied and Environmental Microbiology, v.66, n.3, p.948-955, 2000.

POHRONEZNY, K.; STALL, R.E.; CANTEROS, B.I.; KEGLEY, M.; DATNOFF, L.E.; SUBRAMANYA, R. Sudden shift in the prevalent race of Xanthomonas campestris pv. vesicatoria in pepper fields, in Southern Florida. Plant Disease, v.76, n.2, 1992.

QUEZADO-SOARES, A.M.; LOPES, C.A. Controle químico da mancha-bacteriana em tomateiro para processamento industrial. Summa Phytopathologica, v.25, n.1, p.21, 1999. /Resumo/

QUEZADO-SOARES, A.M.; LEITE, R. P.; LIMA, M. F.; LOPES, C. A. Análise genética de isolados de Xanthomonas campestris pv. vesicatoria por eletroforese de campo pulsado. Fitopatologia Brasileira, v.23, Suplemento, p.215, 1998a. /Resumo/

QUEZADO-SOARES, A.M.; SILVA, V.L.; GIORDANO, L. de B.; LOPES, C.A. Redução na produtividade de tomateiro para processamento industrial devida à manchabacteriana. Horticultura Brasileira, v.16, n.1, 1998b. /Resumo 266/

QUEZADO-SOARES, A.M.; LOPES, C.A.; LIMA, M.F.; BEZERRA, I.C.; LEITE, R.P. Variabilidade de Xanthomonas campestris pv. vesicatoria em tomate no Brasil. Fitopatologia Brasileira, v.22, Suplemento, p.237, 1997. /Resumo/ 
RADEMAKER, J.L.W.; HOSTE, B.; LOUWS, F.J.; KERSTERS, K.; SWINGS, J.; VAUTERIN, L.; VAUTERIN, P.; BRUIJN, F.J. Comparison of AFLP and rep-PCR genomic fingerprinting with DNA-DNA homology studies: Xanthomonas as a model system. International Journal of Systematic na Evolutionary Microbiology , v.50, p.665-677, 2000.

RESTREPO, S.; VÉLEZ, C.M.; VERDIER, V. Measuring the genetic diversity of Xanthomonas axonopodis pv. manihotis within different fields in Colombia. Phytopathology, v.90, n.7, p.683-690, 2000.

RINALDI, D.A.M.F. Estudo da sensibilidade ao cobre e estreptomicina e caracterização do perfil de plasmídeos em Xanthomonas axonopodis pv. citri. Maringá, 1998. 67p. Dissertação (Mestrado) - Universidade Estadual de Maringá.

RITCHIE, D. F.; DITTAPONGPITCH, V. Copper- and streptomycin-resistant strains and host differentiated races of Xanthomonas campestris pv. vesicatoria in North Carolina. Plant Disease, v.75, n.7, p.733-736, 1991.

RITCHIE, D.F.; KOUSIK, C.S.; PAXTON, T.C. Response of bacterial spot pathogen strains to four major resistance genes in pepper. In: THE NATIONAL PEPPER CONFERENCE. Tampa, 1998. Proceedings. Tampa: FFVA, p.14, 1998.

RODRIGUES NETO, J.; SUGIMORI, M.H.; MALAVOLTA JÚNIOR., V.A. Raças de Xanthomonas campestris pv. vesicatoria (Doidge) Dye, no Estado de São Paulo. Arquivos do Instituto Biológico, v.51, n.1/4, p.13-16, 1984.

ROMERO, A.M.; KOUSIK, C.S.; RITCHIE, D.F. Temperature sensitivity of the hypersensitive response of bell pepper to Xanthomonas axonopodis pv. vesicatoria. Phytopathology, v.92, n.2, 2002. 
SAHIN, F. Detection, identification and characterization of strains of Xanthomonas campestris pv. vesicatoria by traditional and molecular methods, and resistance in Capsicum species to Xanthomonas campestris pv. vesicatoria pepper race 6. Columbus, 1997. 182p. Thesis (Ph.D.) - The Ohio State University.

SAHIN, F.; MILLER, S.A. First report of pepper race 6 of Xanthomonas campestris pv. vesicatoria, causal agent of bacterial spot of pepper. Plant Disease, v.79, n.11, p.1188, 1995. /Resumo/

SAHIN, F.; MILLER, S.A. Characterization of Ohio strains of Xanthomonas campestris pv. vesicatoria, causal agent of bacterial spot of pepper. Plant Disease, v.80, n.7, p.773-778, 1996.

SAHIN, F.; MILLER, S.A. A source of resistance in Capsicum spp. accessions to pepper race 6 of of Xanthomonas campestris pv. vesicatoria. Phytopathology, v.87, n.6, Supplement, p.S84, 1997. /Resumo/

SAHIN, F.; MILLER, S.A. Resistance in Capsicum pubescens to of Xanthomonas campestris pv. vesicatoria pepper race 6. Plant Disease, v.82, n.7, p.794-799, 1998.

SCHNEIDER, S.; ROESSLI, D.; EXCOFFIER, L. Alerquin ver.2000: a software for population data analysis. Geneva: Genetics and Biometry Laboratory, University of Geneva, 2000. 111p.

SCOTT, J.W.; JONES, J.B. Sources of resistance to bacterial spot in tomato. HortScience, v.21, n.2, p.304-306, 1986.

SCOTT, J.W.; JONES, J.B.; SOMODI, G.C. Screening tomato accessions for resistance to Xanthomonas campestris pv. vesicatoria, race T3. HortScience, v.30, n.3, p.579-581, 1995. 
SCOTT, J.W.; MILLER, S.A.; STALL, R.E.; JONES, J.B.; SOMODI, G.C.; BARBOSA, V.; FRANCIS, D.L.; SAHIN, F. Resistance to race T2 of the bacterial spot pathogen in tomato. HortScience, v.32, n.4, p.724-727, 1997.

SHAAD, N.W.; VIDAVER, A.K.; LACY, G.H.; RUDOLPH, K.; JONES, J.B. Evaluation of proposed amended names of several pseudomonads and xanthomonads and recommendations. Phytopathology, v.90, n.3, p.208-213, 2000.

SICARD, D.; MICHALAKIS, Y.; DRON, M.; NEEMA, C. Genetic diversity and pathogenic variation of Colletotrichum lindemuthianum in the three centers of diversity of its host, Phaseolus vulgaris. Phytopathology, v.87, n.8, p.807-813, 1997.

SILVA, J.B.C.; GIORDANO, L.B. Produção Mundial e Nacional. In: SILVA, J.B.C; GIORDANO, L.B. (Ed.) Tomate para processamento industrial. Brasília: Embrapa Comunicação para Transferência de Tecnologia / Embrapa Hortaliças, 2000. p. 8-11.

SILVA, V. L.; LOPES, C.A. Isolados de Pseudomonas syringae pv. tomato resistentes a cobre em tomateiros pulverizados com fungicidas cúpricos. Fitopatologia brasileira, v.20, n.1, p.85-89, 1995.

SPOTTS, R.A.; CERVANTES, L.A. Copper, oxytetracycline, and streptomycin resistance of Pseudomonas syringae pv. syringae strains from pear orchards in oregon and Washington. Plant Disease, v.79, n.11, 1132-1135, 1995.

STALL, R.E. Xanthomonas campestris pv. vesicatoria: cause of bacterial spot of tomato and pepper. In: SWINGS, J.G.; CIVEROLO, E.L.. (Ed.). Xanthomonas. London: Chapman \& Hall, 1993. cap.1.10, p.57-60. 
STALL, R.E. Breeding for resistance to bacterial diseases of plants. In: ZAMBOLIM, L.; VALE, F.X.R. (Ed.). Resistência de plantas a doenças, p.51-56, 1997. /Apresentado ao 30. Congresso Brasileiro de Fitopatologia, Poços de Caldas, 1997 - Resumo/

STALL, R.E.; THAYER, P.L. Streptomycin resistance of the bacterial spot pathogen and control with streptomycin. Plant Disease Reporter, v.46, n.6, p.389-392, 1962.

STALL, R. E.; LOSCHKE, D.C.; JONES, J.B. Linkage of copper resistance and avirulence loci on a self-transmissible plasmid in Xanthomonas campestris pv. vesicatoria. Phytopathology, v.76, n.2, 1986.

STALL, R.E.; BEAULIEU, C.; EGEL, D.; HODGE, N.C.; LEITE, R.P.; MINSAVAGE, G.V.; BOUZAR, H.; JONES, J.B.; ALVAREZ, A.M.; BENEDICT, A.A. Two genetically diverse groups of strains are included in Xanhomonas campestris pv. vesicatoria. International Journal of Systematic Bacteriology, v.44, n.1, p.47-53, 1994.

ŠUTIC, D. Bakterioze Crvenog Patlidzana. [Tomato bacteriosis.]. The Review of Applied Mycology, v.36, p.734-735, 1957.

TAI, T. H.; DAHLBECK, D.; CLARK, E. T.; GAJIWALA, P.; PASION, R.; WHALEN, M. C.; STALL, R. E.; STASKAWICZ, B. J. Expression of resitance the Bs 2 pepper gene confers ressitance to bacterial spot disease in tomato. Proceedings National of Academic Science, v. 96, n.24, p. 14153-14158, 1999.

THAYER, P.L.; STALL, R.E. Effect of variation in the bacterial spot pathogen of pepper and tomato on control with streptomycin. Phytopathology, v.51, n.8, p.568-572, 1961. 
VAUTERIN, L.; SWINGS, J.; KERSTERS, K. Grouping of Xanthomonas campestris pathovars by SDS-PAGE of proteins. Journal of General Microbiology, v.137, Part 7, p.1677-1687, 1991.

VAUTERIN, L.; HOSTE, B.; KERSTERS, K.; SWINGS, J. Reclassification of Xanthomonas. International Journal of Systematic Bacteriology, v.45, n.3, p.472489, 1995.

VEIGA FILHO, L.. Arisco vende seu controle acionário por US\$490 milhões. Gazeta Mercantil. Centro-Oeste, Brasília, 8 fev. 2000. p.1.

VOLOUDAKIS, A.E.; BENDER, C.L.; COOKSEY, D.A. Similarity between copper resistance genes from Xanthomonas campestris and Pseudomonas syringae. Applied and Environmental Microbiology, v.59, n.5, p.1627-1634, 1993.

XIA, J.Q.; CORRELL, J.C.; LEE, F.N.; MARCHETTI, M.A.; RHOADS, D.D. DNA fingerprinting to examine microgeographic variatio in the Magnaporthe grisea (Pyricularia grisea) population in two rice fields in Arkansas. Phytopathology, v.83, n.10, p.1029-1035, 1993.

WANG, J.-F.; JONES, J.B.; SCOTT, J.W.; STALL, R.E. A new race of the tomato group of strains of Xanthomonas campestris pv. vesicatoria. Phytopathology, v.80, n.10, p.1070, 1990. /Resumo/

WANG, J.-F.; JONES, J.B.; SCOTT, J.W.; STALL, R.E. Several genes in Lycopersicon esculentum control hypersensitivity to Xanthomonas campestris pv. vesicatoria. Phytopathology, v.84, n.7, p.702-706, 1994. 
WAYNE, L.G.; BRENNER, D.J.; COLWEEL, R.R.; GRIMONT, P.A.D.; KANDLER, O; KRICHEVSKY, M.I.; MOORE, L.H.; MOORE, W.E.C.; MURRAY, R.E.E.; STACKEBRANDT, E.; STARR, M.P.; TRUPER, H.G. Report of the Ad Hoc Commitee on Reconciliation of Approaches to Bacterial Systematics. International Journal of Systematic Bacteriology, v.37, n.4., p.463-464, 1987.

WHALEN, M.; STALL, R.E.; STASKAWICZ, B.J. Characterization of a gene from a tomato pathogen determining hypersensitive resistance in non-host species and genetic analysis of this resistance in bean. Proceeding of National Academy of Science USA, v.85, 6743-6747, 1988.

WHALEN, M.C.; WANG, J-F; GARLAND, F.M.; HEISKELL, M.E.; DAHLBECK, D.; Avirulence gene avrRxv from Xanthomonas campestris pv. vesicatoria specifies resistance on tomato line Hawaii 7998. Molecular Plant-Microbe Interactions, v.6, n.5, p.616-627, 1993.

WILSON, K. Preparation of genomic bacteria. In: AUSUBEL, F. M.; BRENT, R.; KINGSTON, R. E., MOORE, D. D.; SEIDMAN, J. G.; SMITH, J. A.; STRUHL, K. (Ed.). Short protocols in molecular biology. New York: John Wiley, 1999. p.2-14.

YOUNG, J. M.; SADDLER, G. S.; TAKIKAWA, U.; DE BOER, S. H.; VAUTERIN, L; GARDAN, L.; GVOZDYAK, R. I.; STEAD, D. E. Names of plant pathogenic bacteria 1864-1995. Review of Plant Pathology, v.75, p.721-763, 1996.

YOUNG, J.M.; BULL, C.T.; DE BOER, S.H.; FIRRAO, G.; GARDAN, L.; SADDLER, G.E.; STEAD, D.E.; TAKIKAWA, Y. Classification, nomenclature, and plant pathogenic bacteria - a clarification. Phytopathology, v.91, n.7, p.617-620, 2001. 
YU, Z.H.; WANG, J.F.; STALL, R.E.; VALLEJOS, C.E. Genomic localization of tomato genes that control a hypersensitive reaction to Xanthomonas campestris pv. vesicatoria (Doidge) Dye. Genetics, v.141, n.2, p.675-682, 1995.

ZHANG, Y.; GEIDER, K. Differentiation of Erwinia amylovora strains by pulsed-field gel electrophoresis. Applied and Environmental Microbiology, v.63, n.11, p.44214426, 1997. 